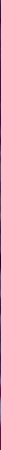

U.S. DEPARTMENT OF THE INTERIOR

U.S. GEOLOGICAL SURNEY

\title{
Hydrogeology of Picacho Basin, South-Central Arizona
}

Water-Resources Investigations Report 00-4277

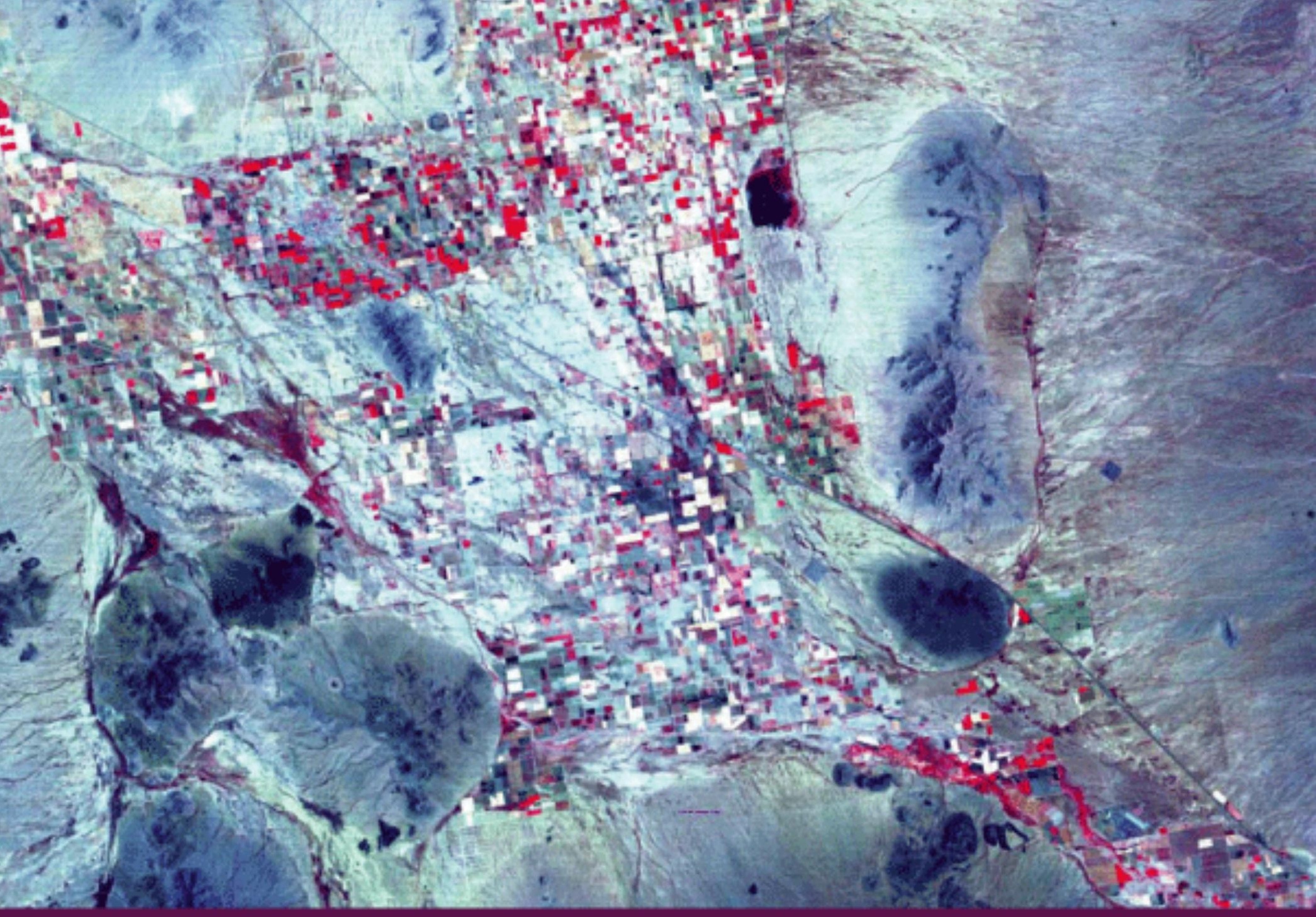




\section{Hydrogeology of Picacho Basin, South-Central Arizona}

By Donald R. Pool, Robert L. Carruth, and Wesley D. Meehan

Water-Resources Investigations Report 00—4277 


\section{U.S. DEPARTMENT OF THE INTERIOR \\ GALE A. NORTON, Secretary}

U.S. GEOLOGICAL SURVEY

Charles G. Groat, Director

The use of firm, trade, and brand names in this report is for identification purposes only and does not constitute endorsement by the U.S. Geological Survey.

For additional information write to:

District Chief

U.S. Geological Survey

Water Resources Division

520 N. Park Avenue, Suite 221

Tucson, AZ 85719-5035
Copies of this report can be purchased from:

U.S. Geological Survey

Information Services

Box 25286

Federal Center

Denver, C0 80225-0046

Information regarding research and data-collection programs of the U.S. Geological Survey is available on the Internet via the World Wide Web. You may connect to the home page for the Arizona District Office using the URL http://az.water.usgs.gov. 


\section{CONTENTS}

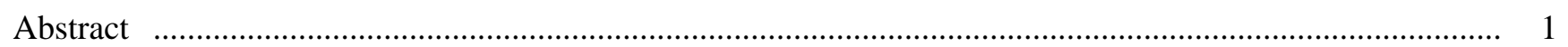

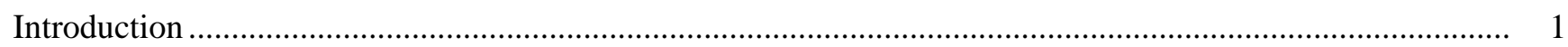

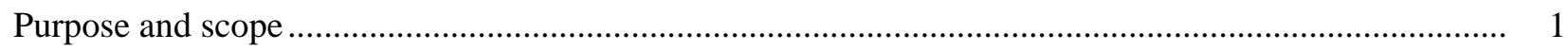

Acknowledgments

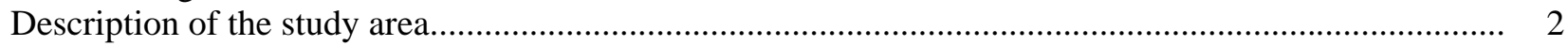

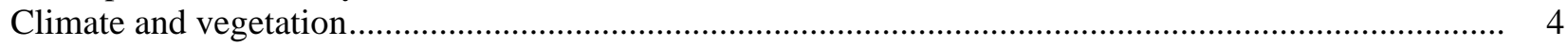

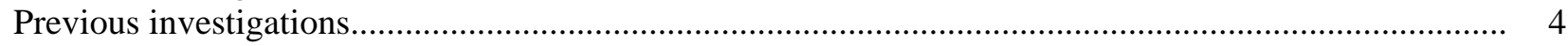

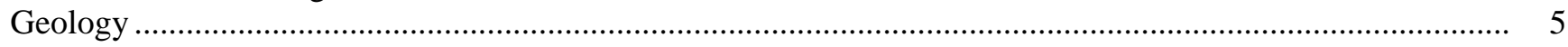

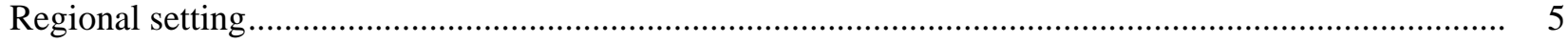

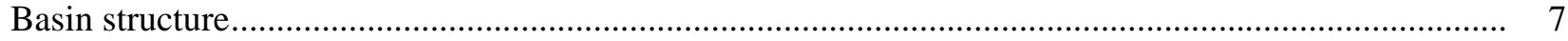

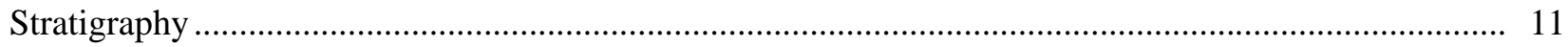

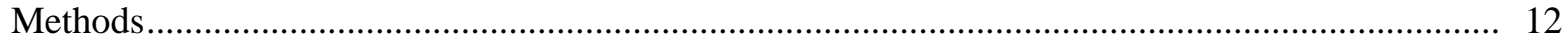

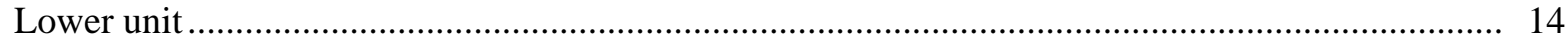

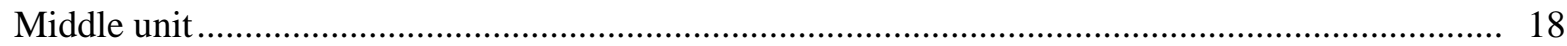

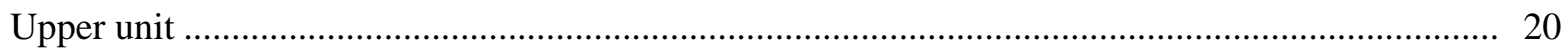

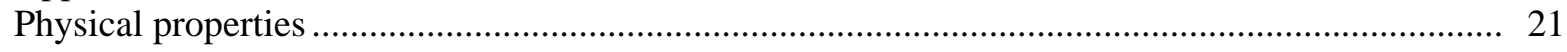

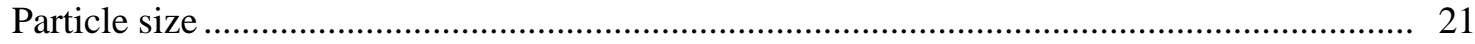

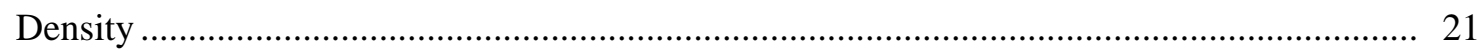

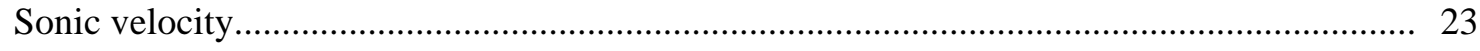

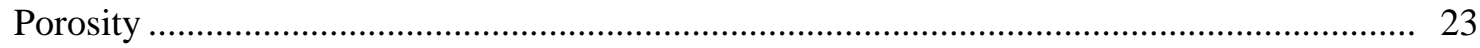

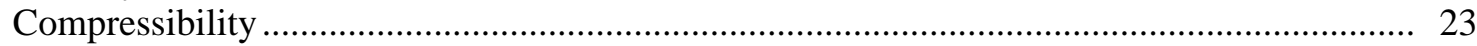

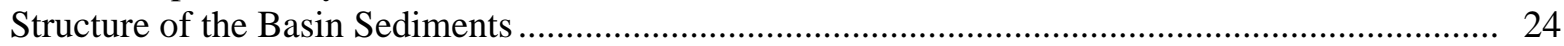

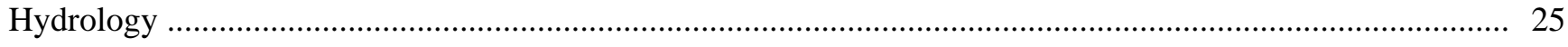

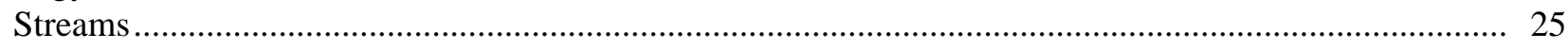

Predevelopment

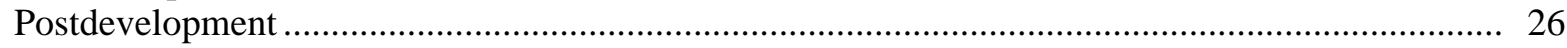

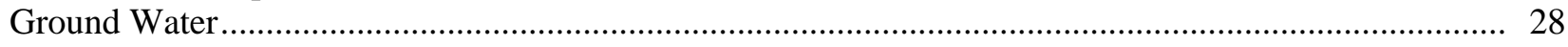

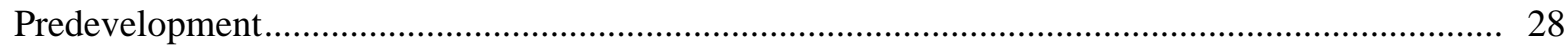

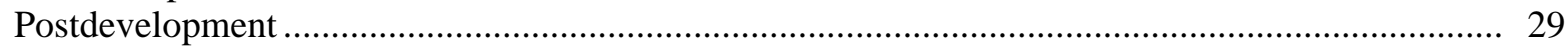

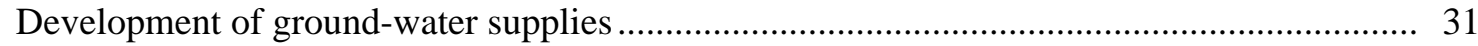

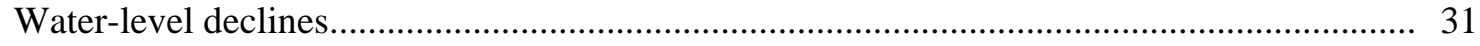

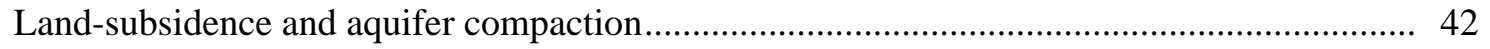

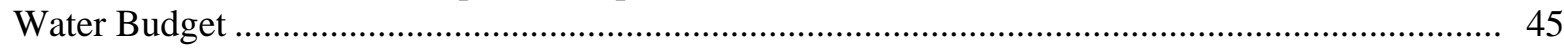

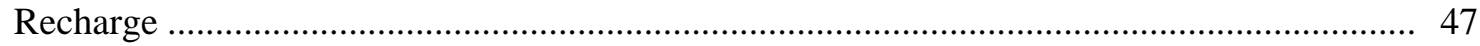

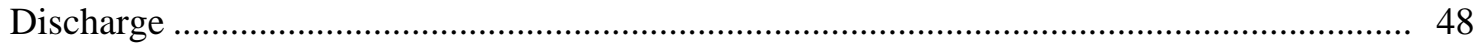

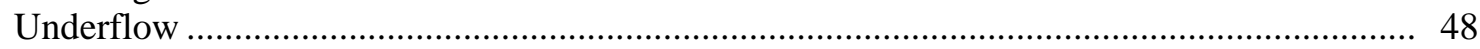

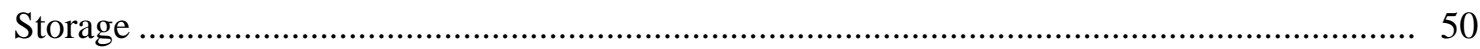

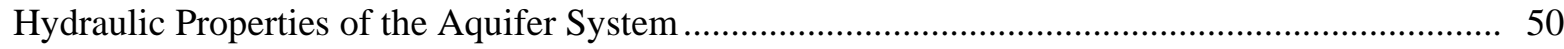

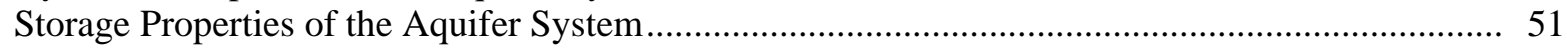

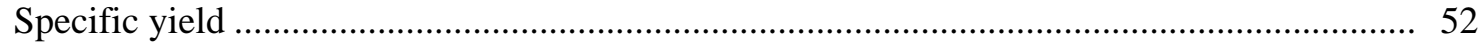

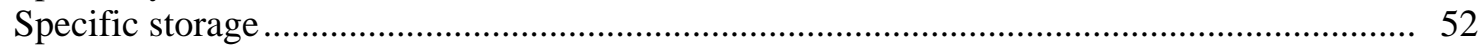

Gravity and land-subsidence measurements of storage change and storage properties ............ 57

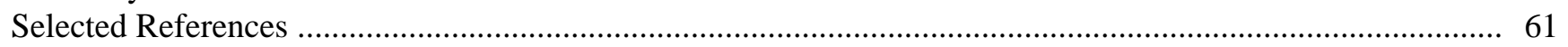




\section{FIGURES}

1-2. Maps showing:

1. Location of study area, Gila Low region (Peirce, 1974), and Arizona's water provinces.............. 2

2. Physiographic and cultural features in Picacho Basin, Arizona................................................. 3

3. Graph showing annual precipitation and the 11-year moving average at Collidge,

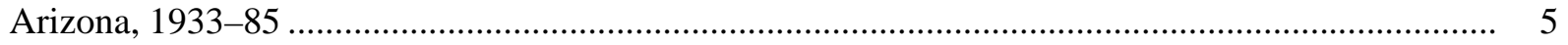

4-6. Maps showing:

4. Generalized geology of Picacho Basin, Arizona....................................................................... 6

5. Residual Bouguer gravity anomaly and faults in Picacho Basin, Arizona ................................... 8

6. Well logs, seismic lines, and geologic sections of Picacho Basin, Arizona .................................. 9

7-8. Charts showing:

7. Correlation of local and regional basin sedimentary units ................................................. 12

8. Description of sedimentary units in Picacho Basin, Arizona .................................................. 13

9. Geologic sections of Picacho Basin, Arizona...................................................................... 15

10-11. Maps showing:

10. Structure contours of lower-unit evaporites, well logs, and faults in

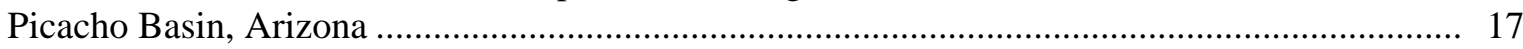

11. Distribution of middle-unit gypsum deposits in Picacho Basin, Arizona .................................... 19

12. Geologic sections showing density and sonic velocity of sediments in

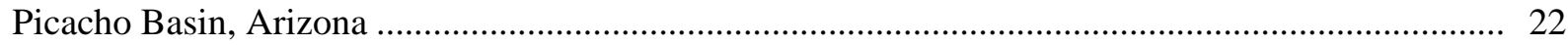

13-14. Graphs showing:

13. Density of basin sediments in the Basin and Range physiographic province of Arizona..............23

14. Flow and diversions of the Gila River, Arizona.

A. Annual runoff at Kelvin27

B. Annual runoff and diversions at Ashurst-Hayden Dam.27

15. Map showing predevelopment water-level altitudes in the upper unit of

Picacho Basin, Arizona

16-17. Graphs showing:

16. Annual well construction in Picacho Basin, Arizona, 1900-84.....

17. Cumulative length of open interval in wells in the upper and lower aquifer systems in Picacho Basin, Arizona, 1900-83

18. Map showing selected observation wells and primary level line in Picacho Basin, Arizona ............. 33

19. Hydrographs showing water levels in selected observation wells in Picacho Basin, Arizona............ 34

20-26. Maps showing:

20. Water-level decline from predevelopment to 1950 in Picacho Basin, Arizona ............................ 36

21. Water-level decline from predevelopment to 1965 in Picacho Basin, Arizona ............................ 37

22. Water-level decline from predevelopment to 1977 in Picacho Basin, Arizona ............................. 38

23. Water-level decline from predevelopment to 1985 in the upper aquifer system of Picacho Basin, Arizona .....

24. Water-level decline from predevelopment to 1985 in the lower aquifer system in the western part of Picacho Basin, Arizona

25. Water-level altitude and direction of ground-water flow for 1965 in the upper aquifer system of Picacho Basin, Arizona.

26. Water-level altitude for 1985 in the lower aquifer system in the western part of Picacho Basin, Arizona 
27-31. Graphs showing:

27. Water-level altitude for 1985 and bottom-hole altitude for wells in the Eloy area ..................... 44

28. Land subsidence along the primary level line, 1905-84 ….................................................... 44

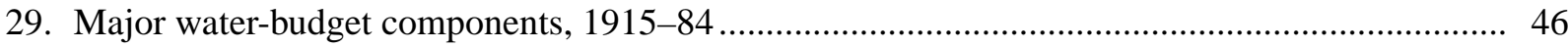

30. Stress-strain relation at the observation wells near the primary level line .................................. 54

31. Stress-strain relation at the extensometer near Eloy ............................................................... 54

32. Logs showing calculated void ratio and specific storage at wells 100 and 105 ........................... 56

33-34. Graphs showing:

33. Gravity, water level, and ground-water storage changes along a portion of the primary level line, $1967-84$.

34. Ratio of ground water withdrawn from aquifer-system compaction to total ground water withdrawn from aquifer-system storage along a portion of the primary level line, 1967-84

\section{TABLES}

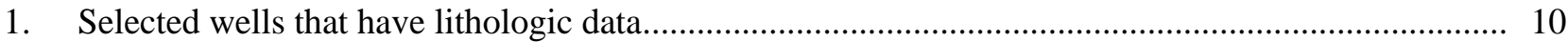

2. Comparison of ground-water flow components during early development .................................... 46

3. Ground-water budget components for selected periods ...................................................... 49

4. Specific-yield calculations for selected periods ...................................................................... 52

\section{CONVERSION FACTORS}

\begin{tabular}{rll}
\hline Multiply & By & To obtain \\
inch $(\mathrm{in})$. & 25.4 & millimeter \\
foot $(\mathrm{ft})$ & 0.3048 & meter \\
mile $(\mathrm{mi})$ & 1.609 & kilometer \\
square mile $\left(\mathrm{mi}^{2}\right)$ & 2.590 & square kilometer \\
acre-foot $(\mathrm{ft})$ & 0.001233 & cubic hectometer \\
cubic foot per second $\left(\mathrm{ft}^{3} / \mathrm{s}\right)$ & 0.02832 & cubic meter per second \\
gallon per minute $(\mathrm{gal} / \mathrm{min})$ & 0.06309 & liter per second \\
gallon per minute per foot $[(\mathrm{gal} / \mathrm{min}) / \mathrm{ft}]$ & 1.154 & liter per minute per meter \\
acre-foot per acre $(\mathrm{acre}-\mathrm{ft} / \mathrm{acre})$ & 0.003048 & cubic hectometer per hectare \\
foot squared per day $(\mathrm{ft} / \mathrm{d})$ & 0.0929 & meter squared per day \\
pound, avoirdupois $(\mathrm{lb})$ & 4.536 & kilogram \\
foot per day per foot $[(\mathrm{ft} / \mathrm{d}) / \mathrm{ft}]$ & 1.000 & meter per day per meter \\
foot per mile $(\mathrm{ft} / \mathrm{mi})$ & 0.1894 & meter per kilometer \\
pound per square inch $\left(\mathrm{lb} / \mathrm{in}^{2}\right)$ & 6.895 & kilopascal \\
\hline
\end{tabular}

In this report, temperature is reported in degrees Fahrenheit $\left({ }^{\circ} \mathrm{F}\right)$, which can be converted to degrees Celsius $\left({ }^{\circ} \mathrm{C}\right)$ by the following equation:

$$
{ }^{\circ} \mathrm{C}=\left({ }^{\circ} \mathrm{F}-32\right) / 1.8 \text {. }
$$


Chemical concentration and water temperature are given only in metric units. Chemical concentration in water is given in milligrams per liter $(\mathrm{mg} / \mathrm{L})$ or micrograms per liter $(\mu \mathrm{g} / \mathrm{L})$. Milligrams per liter is a unit expressing the solute mass per unit volume (liter) of water. One thousand micrograms per liter is equivalent to 1 milligram per liter. For concentrations less than 7,000 milligrams per liter, the numerical value is about the same as for concentrations in parts per million. Specific conductance is given in microsiemens per centimeter $(\mu \mathrm{S} / \mathrm{cm})$ at $25^{\circ} \mathrm{C}$. Grams per kilogram is equal to parts per million (ppm). Micrograms per kilogram are equal to parts per billion (ppb).

\section{VERTICAL DATUM}

Sea level: In this report "sea level" refers to the National Geodetic Vertical Datum of 1929 (NGVD of 1929)-a geodetic datum derived from a general adjustment of the first-order level nets of both the United States and Canada, formerly called "Sea Level Datum of 1929". 


\title{
Hydrogeology of Picacho Basin, South-Central Arizona
}

\author{
By Donald R. Pool, Robert L. Carruth, and Wesley D. Meehan
}

\begin{abstract}
The hydrogeology of Picacho Basin was studied to define the stratigraphy, basin structure, physical and hydraulic properties of the basin sediments, and predevelopment and postdevelopment conditions of ground-water flow as of 1985. The study area includes about 900 square miles and contains a sedimentfilled asymmetric graben. The greatest sediment thickness occurs along the east margin of the graben. Basin sediments contain the principal water-bearing units and are separated into lower, middle, and upper units. The lower unit is several thousand feet thick and contains a conglomerate facies and a playa facies that contains a thick evaporite sequence. The middle and upper units contain alluvial and playa facies that are as much as 1,500 feet thick. Ground water occurs in lower and upper aquifer systems separated by a middle confining unit that comprises the playa facies of the three units. Hydraulic properties and compressibility of the middle and upper units are much greater than those of the lower unit. Vertical-head gradients exist, and vertical flow occurs within and between the aquifer systems.

Early development of surface-water supplies resulted in increased recharge through deep percolation of irrigation water. Later development of the ground-water supplies resulted in extensive water-level declines, changes in the direction of ground-water flow, removal of water from storage, aquifer compaction, land subsidence, and earth fissures. Dewatering of pore spaces in the upper unit has been the primary source of water; however, as much as 80 percent of the water derived from storage in the Eloy area has resulted from compaction of pore spaces.
\end{abstract}

\section{INTRODUCTION}

The hydrogeology of Picacho Basin, south-central Arizona, was investigated as part of a follow-up study to the Southwest Alluvial Basins, Regional AquiferSystem Analysis (Swab/RASA) project (Anderson, 1980). The purpose of the follow-up study was to develop land-surface subsidence-modeling techniques that can be applied to the modular ground-water flow model of McDonald and Harbaugh (1988). As part of the investigation, new modeling techniques were applied to a hydrologic system where subsidence had been documented. Picacho Basin was selected because land-subsidence and water-level data were available. This report documents the conceptualization of the hydrogeologic system in Picacho Basin and presents a framework for construction of the ground-water flow and land-subsidence model.

\section{Purpose and Scope}

This report documents conceptualization of the hydrogeologic system of the Picacho Basin, which required description of the geology and ground-water flow system. Geologic descriptions and physical characteristics of the aquifer were developed from several types of previously collected subsurface information, including drillers', lithologic, and geophysical logs and seismic- refraction data. These 
data were used to characterize basin structure, stratigraphy, and physical characteristics of the basin sediments such as density, porosity, and grain size. Description of the ground-water flow system included analysis of hydraulic and storage properties of the aquifer system and analysis of temporal changes in water- budget components. The water-budget components include ground-water withdrawals, evapotranspiration, discharge to streams, and recharge through infiltration along streams and irrigation-distribution systems. Hydraulic properties of the aquifer were estimated using existing specificcapacity and grain-size data. Aquifer-storage properties were described through analysis of available subsidence, compaction, and gravity data. Changes in the ground-water flow system that had occurred from about 1900 through 1985 were described using hydrographs and maps of water-level altitude and water-level decline. The ground-water data through 1985 are considered because that period includes the greatest change from predevelopment.

\section{Acknowledgments}

Matthew Wickham, Frank Corkhill, Drew Strykowski, William H. Remick, and James Hedley of the Arizona Department of Water Resources provided and discussed data, which included pumpage information for 1980-84. Personnel of the Arizona Geological Survey provided access to their well-cuttings library and pertinent unpublished information.

\section{Description of the Study Area}

Picacho Basin is a structural basin in the Basin and Range lowlands water province of Arizona (fig. 1) and includes about $900 \mathrm{mi}^{2}$. For this study, the basin is defined by hydrologic boundaries that approximate the extent of the primary aquifer. The main hydrologic boundary is impermeable crystalline rock that restricts the flow of ground water and includes the mountains of the study area and crystalline rock underlying the basin sediments (fig. 2). The crystalline rocks also are referred to as bedrock in this report. Mountains of the area partly surround the basin and include several low-lying mountain ranges that are less than $5,000 \mathrm{ft}$ above sea level. The Picacho Mountains and Picacho
Peak are on the east edge of the basin. The Silverbell, Sawtooth, and Silver Reef Mountains are on the south and southwest sides of the basin. The west edge of the basin is formed by the Casa Grande and Sacaton Mountains. The north boundary of the basin is formed by the Santan Mountains and the Gila River. The Tortilla Mountains are on the northeastern extent of the basin.

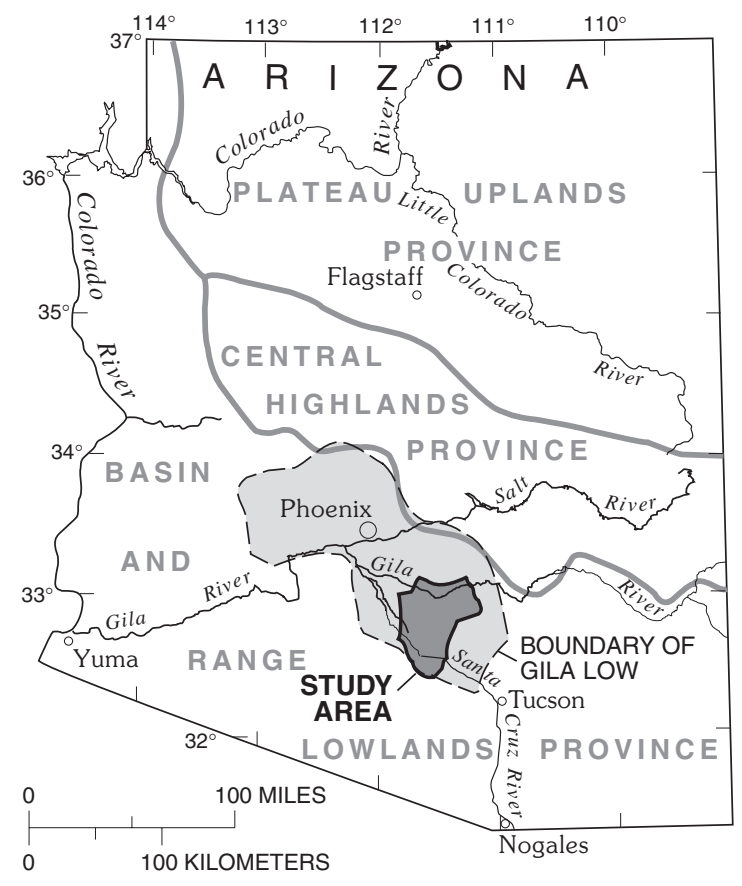

Figure 1. Location of study area, Gila Low region (Peirce, 1974), and Arizona's water provinces.

The valley floor, which includes about $615 \mathrm{mi}^{2}$, consists of younger and older alluvial surfaces. The younger alluvial surface overlies the older surface except near the base of many of the mountains surrounding the basin. The younger alluvial surface slopes at less than $15 \mathrm{ft} / \mathrm{mi}$ from an altitude of $1,900 \mathrm{ft}$ between Picacho Peak and the Silverbell Mountains to about 1,400 ft at Casa Grande and 1,300 ft between the Santan and Sacaton Mountains. The older alluvial surface is associated with alluvial fans and pediments that slope more than $30 \mathrm{ft} / \mathrm{mi}$. The older alluvial surface is exposed in a large area east of the Florence-Casa Grande Canal and slopes upward toward the Tortilla Mountains several miles north of the Picacho Mountains (fig. 2). 


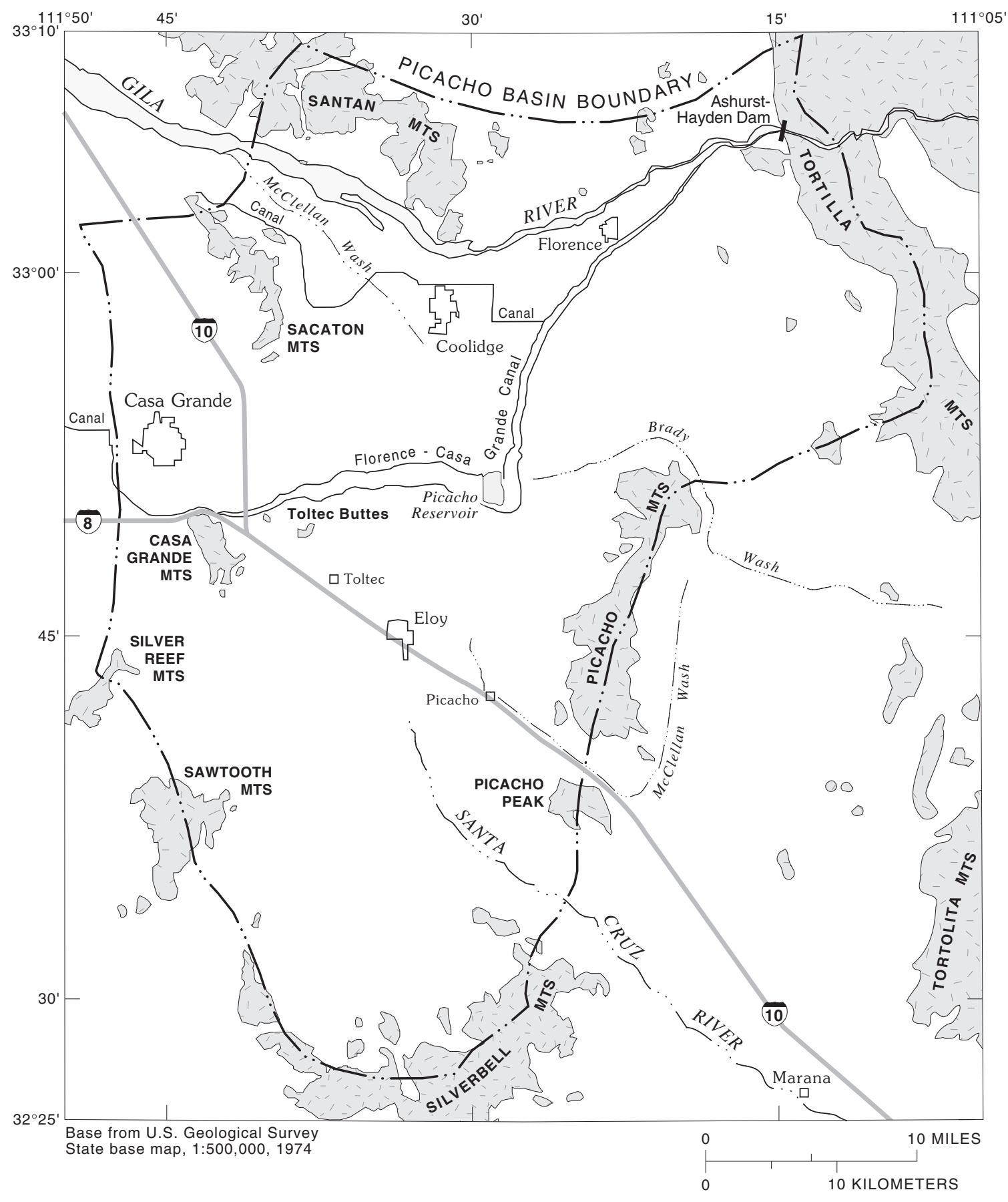

EXPLANATION

BASIN SEDIMENTS AND SURFICIAL

ALLUVIAL DEPOSITS

CRYSTALLINE ROCK

Figure 2. Physiographic and cultural features in Picacho Basin, Arizona. 
The Gila River is the major stream in the area (fig. 2). Before development of surface-water supplies, the Gila River was an intermittent stream that flowed for long periods of the year and could have been perennial throughout the reach within the study area. At present, flow in the river is controlled partly by upstream reservoir releases and diversions at AshurstHayden Dam (fig. 2). Other streams generally flow only in response to local precipitation and include the Santa Cruz River and McClellan Wash, which have poorly defined distributary channels in the western part of the basin. Intense rainfall along the Santa Cruz River drainage southeast of the basin occasionally produces large flows in the study area.

Agriculture has increased in the study area since the late 1800's and has occupied nearly all the younger alluvial surface at different times. Much of the agriculture in the northern part of the basin is irrigated with water from the San Carlos Irrigation Project, which distributes diverted Gila River flows and ground water withdrawn from wells in the area. The study area includes several towns that support the agricultural industry (fig. 2). Florence and Coolidge are near the Gila River in the northern part of the basin. Eloy and Picacho are in the basin center. Casa Grande, at the west boundary of the basin, is the largest community in the area.

Development of the water resources and agricultural potential of the study area began with the indigenous people; their water use was not recorded, but probably was not significant compared to the use by later settlers to the area. For the purposes of this report, the term "predevelopment" refers to the period before the 1880s when European settlers moved into the area and constructed water-supply and delivery systems for farms and towns. This early development period lasted until about 1920 when a postwar influx of people and increased demand for agricultural products led to a marked increase in development of the water resources. This postdevelopment period extends from the 1920 s to the present.

\section{Climate and Vegetation}

The study area is semiarid, and temperatures range from about $32^{\circ} \mathrm{F}$ to more than $100^{\circ} \mathrm{F}$. Average daily high temperatures range from about $66^{\circ} \mathrm{F}$ in January to $107^{\circ} \mathrm{F}$ in July. Average daily low temperatures range from about $34^{\circ} \mathrm{F}$ in January to about $75^{\circ} \mathrm{F}$ in July (Sellers and others, 1985).
Annual precipitation averages about 8.5 in. at Coolidge. Precipitation may be slightly higher in the mountains; however, the mountains occupy a small area compared with the valley floor and have maximum altitudes that are only 1,000 to $2,000 \mathrm{ft}$ above the valley floor. Precipitation records collected since 1931 at Casa Grande and Coolidge (Sellers and others, 1985) indicate that the greatest monthly precipitation is more than 1 in. during July, August, and December; 0.70 to 0.80 in. during most fall and winter months, and less than 0.30 in. during April through June. The long-term precipitation records at Coolidge (fig. 3) indicate that annual precipitation typically varies by 5 in. or more. Annual precipitation extremes ranged from a high of 19.21 in. in 1941 to a low of 3.56 in. in 1956.

An 11-year moving average of the annual precipitation at Coolidge (fig. 3) indicates that the average precipitation has varied by about 2 in. during the period of record. Average annual precipitation was $8.5 \mathrm{in}$. during the late $1930 \mathrm{~s}$, decreased to $7.5 \mathrm{in}$. during the late 1950s, and increased again to $9.5 \mathrm{in}$. during the late 1970s.

Native vegetation significant to the ground-water system includes phreatophytes that occur near the flood plain of the Gila River. Phreatophytes can be a significant discharge source in these areas of shallow ground water. Types of phreatophytes that are native to the area include cottonwood, willow, and mesquite (Gatewood and others, 1950). Non-native saltcedar was introduced to the area before 1930 (Robinson, 1965).

\section{Previous Investigations}

Several hydrologic studies have included Picacho Basin or part of the basin. Studies documenting ground-water and surface-water conditions in the area during early development include those by Davis (1897a, b), Lee (1904), Lippincott (1900), Olberg (1915, 1919), Southworth (1919), Thomsen and Baldys (1985), and Freethey and Anderson (1986). Babcock (1970), Hardt and Cattany (1965), Konieczki and English (1979), Smith (1940), Thomsen and Baldys (1985), Turner and others (1943), and Wickham and Corkhill (1989) provided information on the hydrologic system during extensive development of the water supply. Water-level information was provided by Wallace and others (1986). 


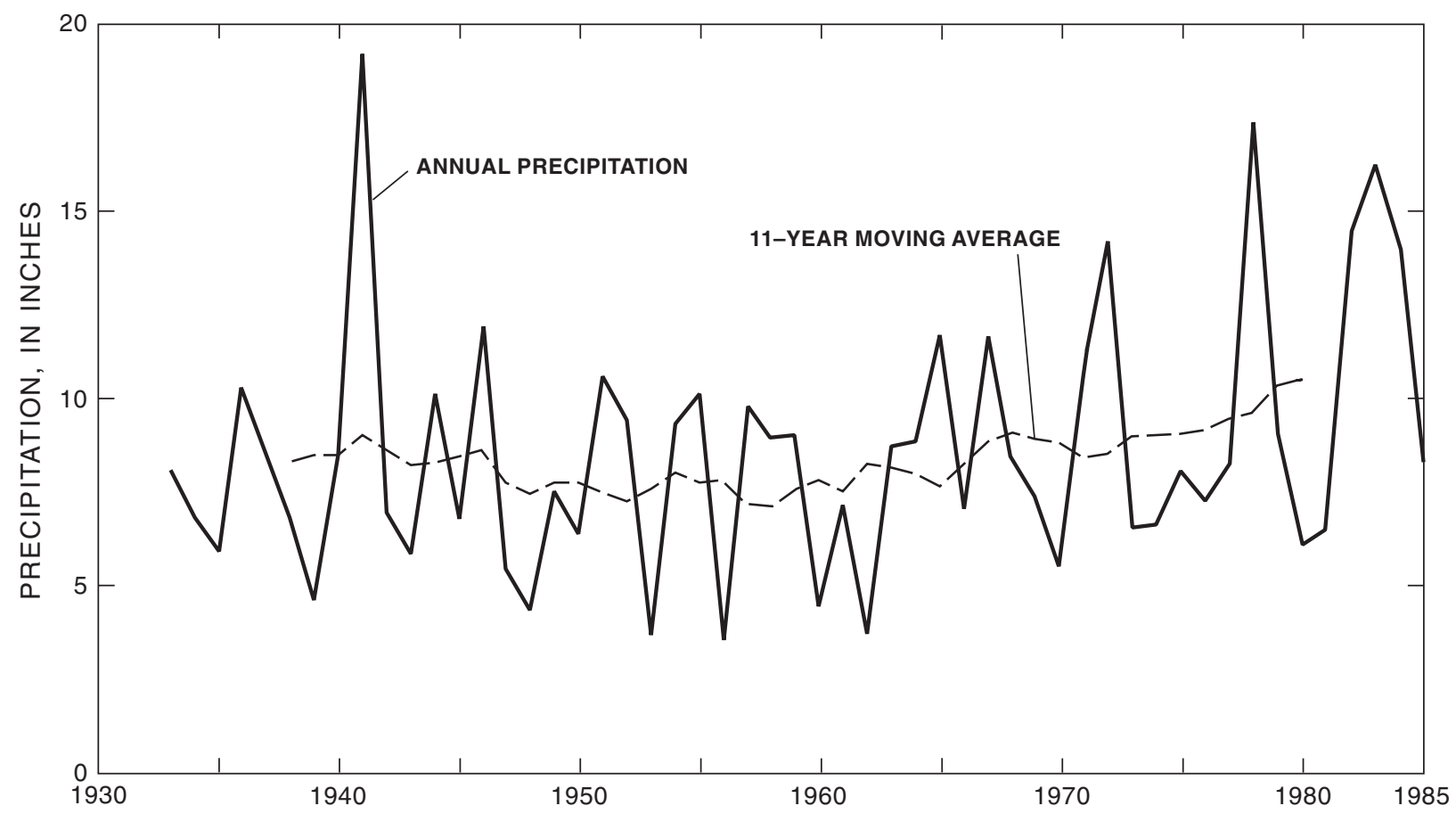

Figure 3. Annual precipitation and the 11-year moving average at Collidge, Arizona, 1933-85.

Geologic and geophysical studies of the region include those by Hardt and Cattany (1965), Bureau of Reclamation (1977), Christie (1978), Feth (1951), Cummings (1982), Nason and others (1982), Laney and Pankratz (1985), Holzer (1978), and Shafiqullah and others (1980). Subsidence in the area has been documented by Robinson and Peterson (1962), Winikka (1964), Schumann and Poland (1970), Laney and others (1978), Byars (1975), Jachens and Holzer (1979), and Strange (1983).

\section{GEOLOGY}

\section{Regional Setting}

Picacho Basin lies in the Basin and Range geologic province of southern Arizona (Damon and others, 1984), which is characterized by sharply rising mountains of moderate relief separated by broad alluvial basins. The mountains and basins are associated with upthrown and down-thrown structural blocks, respectively, which are a result of the Basin and Range structural disturbance that occurred 15 to 8 m.y.B.P. (Shafiqullah and others, 1980). Mountains of the study area are mainly bedrock composed of metamorphic, granitic, and volcanic rocks of late Tertiary and older age (fig. 4). Metamorphic rocks occur in the Picacho Mountains. Granitic rocks occur in most of the mountains on the west and north margins of the basin and underlie the basin sediments in the northwest region of the basin. Faulted and tilted volcanic rocks compose the mountains at the south margin of the basin and underlie the basin sediments in that region. Flat-lying basalt flows of late Tertiary age overlie the granitic rocks in the Santan Mountains and may underlie sediments in the extreme northern part of the basin.

Crystalline rocks occur in lower and upper plates that underwent ductile and brittle deformation, respectively, during middle to late Tertiary regional extension (Brooks, 1986). Metamorphism and folding occurred in the lower plate beneath a detachment fault (fig. 4). Metamorphic rocks of the lower plate occur only in the Picacho Mountains. Granitic and volcanic rocks of the upper plate occupy most of the surrounding mountains and lie above the detachment fault where regional extension was accommodated by listric normal faulting. Listric normal faults generally are steeply dipping near the surface and progressively flatten to horizontal with depth. Movement along these faults resulted in structural blocks that are tilted away from the direction of movement. The detachment fault is exposed only at the south end of the Picacho Mountains (fig. 4) but probably lies at depth beneath basin sediments and other upper-plate rocks of the area. 


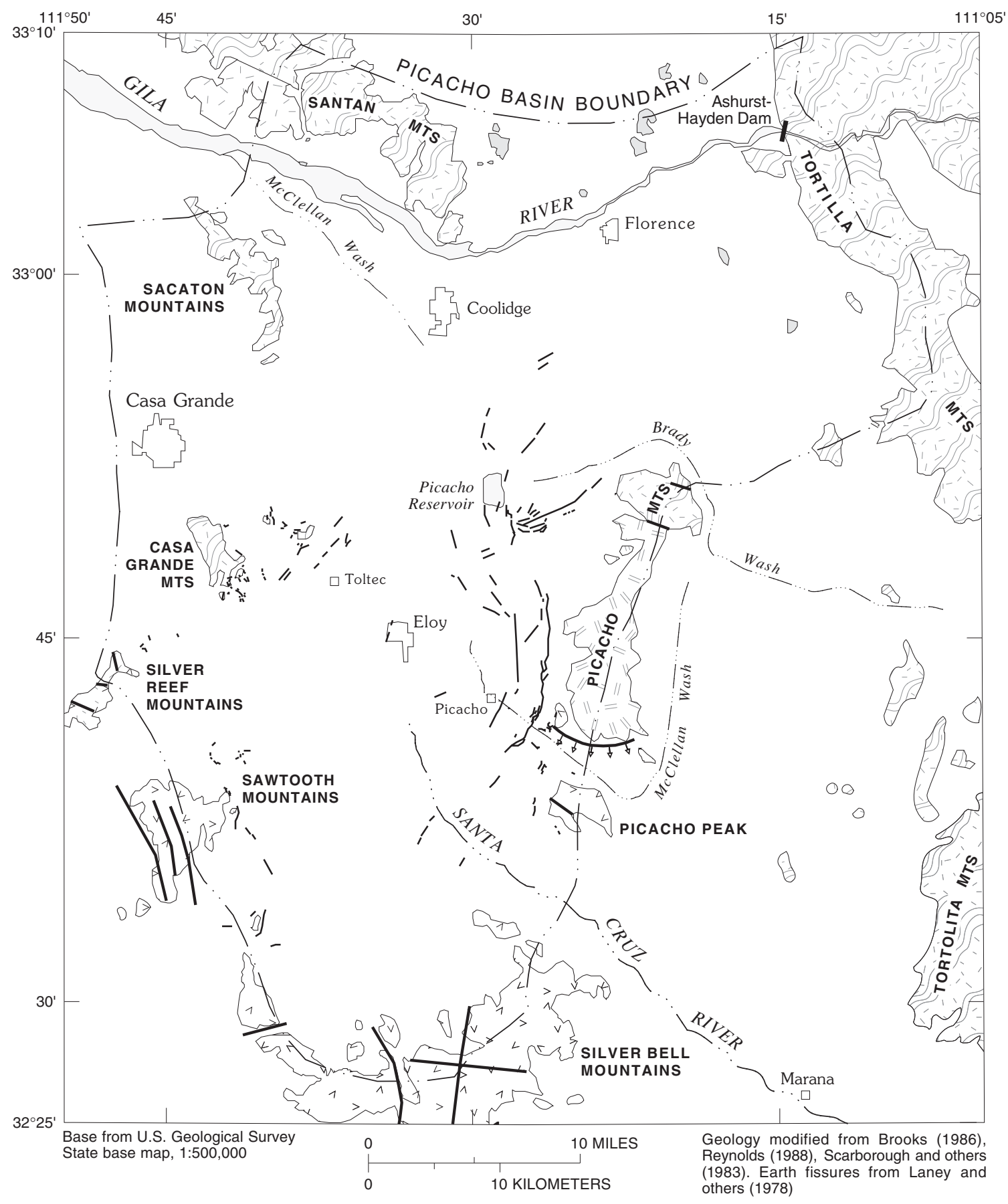

EPLANATION

UPPER PLATE

BASIN SEDIMENTS AND SURFICIAL ALLUVIAL DEPOSITS

CRYSTALLINE ROCK

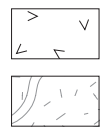

VOLCANIC ROCKS

GRANITIC AND

METAMORPHIC

ROCKS

LOWER PLATE

METAMORPHIC ROCKS

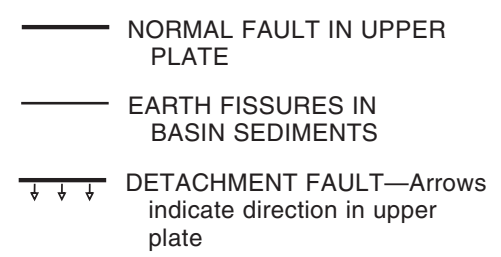

NORMAL FAULT IN UPPER

BASIN SEDIMENTS

indicate direction in upper plate

Figure 4. Generalized geology of Picacho Basin, Arizona. 
Detailed structural investigations of upper-plate ore deposits near Casa Grande and Florence (Cummings, 1982; Nason and others, 1982) indicate that faulting is extensive. Faults generally trend northwest or northeast, and major structures generally are less than $1 \mathrm{mi}$ apart. The intervening structural blocks have easterly dips indicating westerly extension of the upper plate. Displacements on major faults typically are several hundred to $2,000 \mathrm{ft}$.

Picacho Basin is one of several basins in central Arizona that collectively are known as the Gila Low (Peirce, 1974; fig. 1, this report). The Gila Low, a region of closed drainage during the early stages of the Basin and Range structural disturbance, contains more than 10,000 ft of basin sediments and evaporites within three major basins (Oppenheimer and Sumner, 1981). Through-flowing drainage developed in the area after the Basin and Range disturbance. The area continued to be a depositional center during the late Pliocene and Pleistocene Epochs. During this period, several hundred feet of basin sediments and alluvium were deposited along the present-day drainages of the Salt and Gila Rivers (Laney and Hahn, 1986; Brown and Pool, 1989).

\section{Basin Structure}

Basin structure has influenced the areal distribution of the lithology, thickness, and hydraulic properties of sediments that form the main aquifer. Description of the basin structure includes the lateral and vertical dimensions of the structural depression and the faulting and tilting of the basin sediments. Most basins in the Basin and Range lowlands province consist of a downthrown structural region, a graben, that is bounded by normal faults (Shafiqullah and others, 1980). The graben generally is asymmetrically located in the basin and may be much smaller in areal extent than the physiographic basin (Pool, 1986). In some basins, graben asymmetry is caused by half grabens or rotated fault blocks. The part of the physiographic basin surrounding the graben is a result of erosion and partial burial of the mountain blocks. The graben influenced the distribution of hydraulic properties of the aquifer because large percentages of fine-grained sediments and large thickness of sediments are found in the graben in comparison with other parts of the basin.

The asymmetric distribution of the residual Bouguer gravity anomaly (fig. 5) indicates that the general structure of the basin is a rotated fault block with the gradient structural relief near the east margin of the basin. The gravity map is derived from more than 2,900 complete Bouguer gravity-anomaly values that have been corrected for isostasy using a topographically based correction (Aiken and others, 1981). Steep gravity gradients indicated by closely spaced contours of gravity values, occur where a large change in the thickness of low-density sediments increases across a short lateral distance. Significant basin structures therefore can be inferred from steep gravity gradients. The steepest gravity gradients occur adjacent to the east margin of the basin. Steep gravity gradients also are found on the north and south margins of the basin and between the northern and southern parts of the basin. Some of these structures probably are major faults that define the graben boundaries. A lack of major fault displacements on the west margin of the basin is inferred from the absence of steep gravity gradients.

The graben in Picacho Basin is defined by two major regions of low gravity values (fig. 5). A major northeastward- to southwestward-trending region of low gravity values occurs in the southern part of the basin, and a northwestward- to southeastward-trending region of low gravity values occurs in the northern part of the basin. The southern part contains significantly lower gravity values.

The gravity gradient between the northern and southern parts of the basin probably has multiple causes that include a detachment fault extending beneath basin sediments, lower density deposits in the southern part, and a larger thickness of sediments in the southern part. The occurrence of steep gravity gradients associated with a detachment fault is in agreement with the observed fault at the south end of the Picacho Mountains (fig. 4) and low-density volcanic rocks south of the fault. A gravity gradient that is steeper within the basin than in the mountains indicates that the gradient within the basin is at least partly associated with the low-density deposits or a larger thickness of sediments. Several hundred feet of anhydrite occur in the northern part of the basin and may enhance steep gravity gradients between the northern and southern parts of the basin, although the occurrence of thick anhydrite in the southern part is unknown. A small area of high gravity values (fig. 5) occurs near the east-central part of the basin and coincides with the greatest known thickness of anhydrite, which is several thousand feet at well 100 (fig. 6). Local well numbers are given in table 1. 


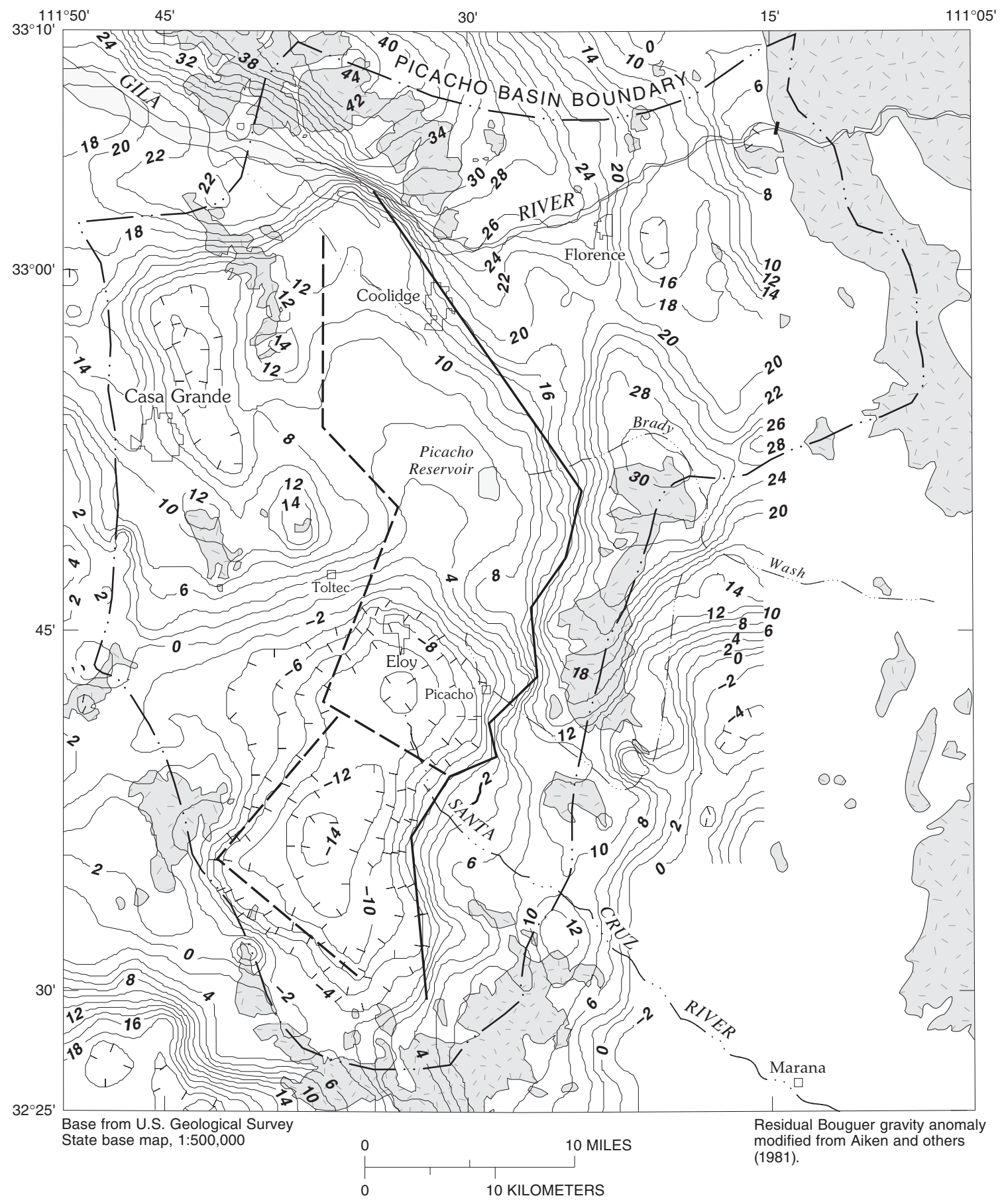

EXPLANATION

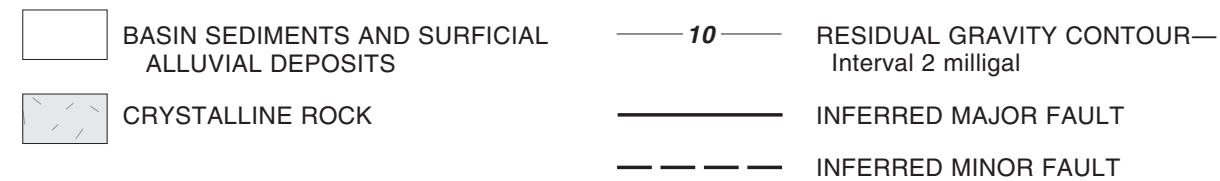

Figure 5. Residual Bouguer gravity anomaly and faults in Picacho Basin, Arizona. 


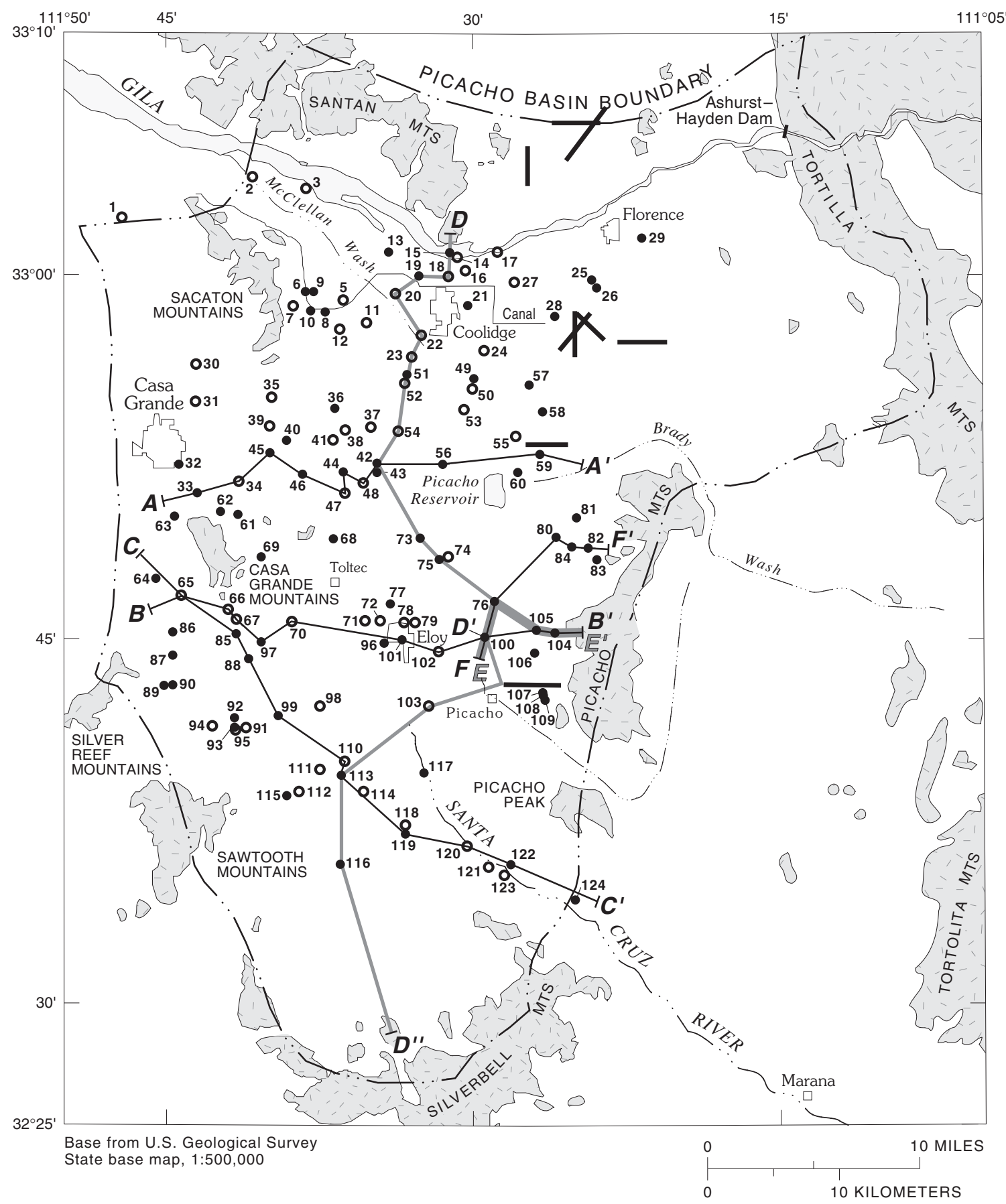

EXPLANATION

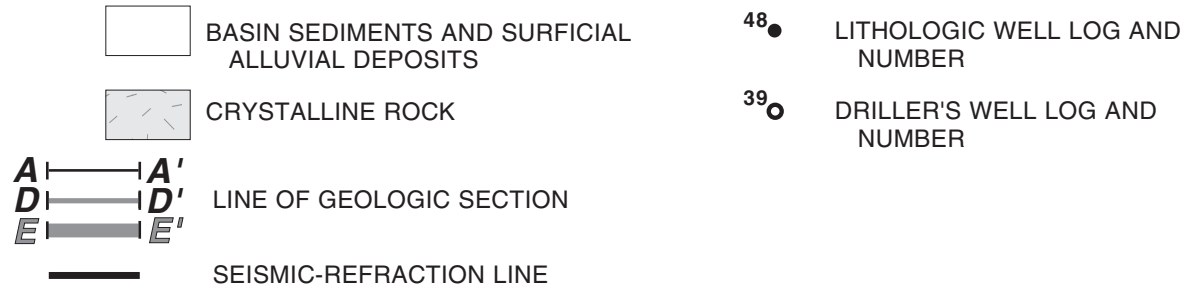

Figure 6. Well logs, seismic lines, and geologic sections of Picacho Basin, Arizona. 
Table 1. Selected wells that have lithologic data

\begin{tabular}{|c|c|c|c|c|c|c|c|c|}
\hline $\begin{array}{c}\text { Well } \\
\text { number } \\
\text { used in } \\
\text { report }\end{array}$ & Local well number & $\begin{array}{l}\log \\
\text { depth, in } \\
\text { feet }\end{array}$ & $\begin{array}{c}\text { Well } \\
\text { number } \\
\text { used in } \\
\text { report }\end{array}$ & Local well number & $\begin{array}{l}\text { Log depth, } \\
\text { in feet }\end{array}$ & $\begin{array}{c}\text { Well } \\
\text { number } \\
\text { used in } \\
\text { report }\end{array}$ & Local well number & $\begin{array}{l}\text { Log depth, } \\
\text { in feet }\end{array}$ \\
\hline 1 & (D-04-06)31bad & 490 & 43 & (D-06-07)25cdd2 & 810 & 84 & (D-07-09)16aca & 1,630 \\
\hline 2 & (D-04-07)19bdd & 533 & 44 & (D-06-07)27ddd2 & 1,370 & 85 & (D-08-06)02daa & 1,070 \\
\hline 3 & (D-04-07)27bbb & 460 & 45 & (D-06-07)30baa3 & 655 & 86 & (D-08-06)05add & 350 \\
\hline 4 & (D-04-07)36cdb & 840 & 46 & (D-06-07)32aaa & 1,000 & 87 & (D-08-06)08add & 790 \\
\hline 5 & (D-05-07)14ddc & 1,230 & 47 & (D-06-07)34ddd2 & 2,540 & 88 & (D-08-06)12cbd & 1,260 \\
\hline 6 & (D-05-07)15bcc & 670 & 48 & (D-06-07)35add4 & 2,538 & 89 & (D-08-06) $17 \mathrm{dcc}$ & 500 \\
\hline 7 & (D-05-07)21abc & 690 & 49 & (D-06-08)03aad & 2,130 & 90 & (D-08-06)17ddd & 610 \\
\hline 8 & (D-05-07)22add1 & 730 & 50 & (D-06-08)S03bdd2 & 1,750 & 91 & (D-08-06)25cdd & 800 \\
\hline 9 & (D-05-07)22bac & 800 & 51 & (D-06-08)06add & 2,580 & 92 & (D-08-06)26add & 1,475 \\
\hline 10 & (D-05-07)22bdc & 900 & 52 & (D-06-08)06dca & 2,758 & 93 & (D-08-06)26ddd2 & 1,505 \\
\hline 11 & (D-05-07)24dcc & 1,555 & 53 & (D-06-08)10dcc & 1,330 & 94 & (D-08-06)27ddd & 533 \\
\hline 12 & (D-05-07)26aca & 1,400 & 54 & (D-06-08)18cdd & 3,265 & 95 & (D-08-06)35aaa & 935 \\
\hline 13 & (D-05-08)07baa & 640 & 55 & (D-06-08)24ada & 1,850 & 96 & (D-08-07)01ddd & 1,090 \\
\hline 14 & (D-05-08)10aca & 800 & 56 & (D-06-08)28dbb2 & 1,100 & 97 & (D-08-07)06cdd & 1,139 \\
\hline 15 & (D-05-08)10bad & 875 & 57 & (D-06-09)06dcd & 1,050 & 98 & (D-08-07)21ddd & 1,700 \\
\hline 16 & (D-05-08)11ccc & 685 & 58 & (D-06-09)17bab & 1,500 & 99 & (D-08-07)30ada & 1,343 \\
\hline 17 & (D-05-08)12aba & 430 & 59 & (D-06-09)29bba1 & 1,800 & 100 & $(\mathrm{D}-08-08) 02 \mathrm{dbc}$ & 10,179 \\
\hline 18 & (D-05-08)15bdb & 970 & 60 & (D-06-09)30ccc & 270 & 101 & (D-08-08)06dca & 1,200 \\
\hline 19 & (D-05-08)17aad & 1,212 & 61 & (D-07-06)01ccc & 610 & 102 & (D-08-08)09bdd2 & 1,280 \\
\hline 20 & (D-05-08)19aba & 1,200 & 62 & $(\mathrm{D}-07-06) 02 \mathrm{cca}$ & 457 & 103 & (D-08-08)20ddd & 2,508 \\
\hline 21 & (D-05-08)23bdd & 1,050 & 63 & (D-07-06)05ddd & 230 & 104 & (D-08-09)05acd & 1,182 \\
\hline 22 & (D-05-08)29ddd & 591 & 64 & (D-07-06)20ccd & 1,400 & 105 & (D-08-09)05bcb & 1,800 \\
\hline 23 & (D-05-08)32dcc & 600 & 65 & (D-07-06)28ddd & 468 & 106 & (D-08-09)07add & 1,380 \\
\hline 24 & (D-05-08)35dad3 & 1,800 & 66 & (D-07-06)35acc & 825 & 107 & (D-08-09)20bac & 1,190 \\
\hline 25 & (D-05-09)14bcb & 795 & 67 & (D-07-06)35ddd & 602 & 108 & (D-08-09)20bda & 1,060 \\
\hline 26 & (D-05-09)14cac & 1,258 & 68 & (D-07-07)10cdd & 600 & 109 & (D-08-09)20bdd & 1,000 \\
\hline 27 & (D-05-09)18bdd2 & 950 & 69 & (D-07-07) $18 \mathrm{ccc}$ & 480 & 110 & $(\mathrm{D}-09-07) 02 \mathrm{cca}$ & 1,715 \\
\hline 28 & (D-05-09)28bab & 930 & 70 & (D-07-07)32cdd & 1,432 & 111 & (D-09-07)04ddd & 1,000 \\
\hline 29 & (D-05-10)06acb & 1,100 & 71 & (D-07-07)35ddd & 800 & 112 & (D-09-07)08cdc & 1,701 \\
\hline 30 & (D-06-06)04aaa2 & 704 & 72 & (D-07-07)36dcd & 1,115 & 113 & (D-09-07)10add1 & 2,131 \\
\hline 31 & (D-06-06)09dad & 600 & 73 & (D-07-08)08cdd & 8,024 & 114 & (D-09-07)11ddd & 801 \\
\hline 32 & (D-06-06)28cba2 & 510 & 74 & (D-07-08)36ddd2 & 1,260 & 115 & (D-09-07)17baa & 1,688 \\
\hline 33 & $(\mathrm{D}-06-06) 34 \mathrm{cbb}$ & 480 & 75 & (D-07-08)22bab & 1,260 & 116 & (D-09-07)34ada & 2,007 \\
\hline 34 & (D-06-06)35ddd & 1,500 & 76 & (D-07-08)25ccc & 1,944 & 117 & (D-09-08)05ddc & 1,155 \\
\hline 35 & (D-06-07)07bdd & 1,115 & 77 & (D-07-08)31bba & 828 & 118 & (D-09-08)18add & 600 \\
\hline 36 & (D-06-07)10cdd & 1,390 & 78 & (D-07-08)31ddd 2 & 1,000 & 119 & (D-09-08)19ddd & 1,430 \\
\hline 37 & (D-06-07)13cdb & 650 & 79 & (D-07-08)32cdc2 & 1,000 & 120 & (D-09-08)27daa & 914 \\
\hline 38 & (D-06-07)15ddd & 1,838 & 80 & (D-07-09)08ddd & 1,500 & 121 & (D-09-08)35add & 720 \\
\hline 39 & (D-06-07)18cda & 1,000 & 81 & (D-07-09)09aaa & 1,700 & 122 & (D-09-08)36add & 1,350 \\
\hline 40 & (D-06-07)20bdc & 1,200 & 82 & (D-07-09) $15 \mathrm{bdd} 2$ & 1,200 & 123 & (D-09-08)36dcd & 600 \\
\hline 41 & (D-06-07)22bdd & 1,512 & 83 & (D-07-09) $15 \mathrm{dcd}$ & 1,050 & 124 & (D-10-09)10bbb & 360 \\
\hline 42 & (D-06-07)25ddd & 4,742 & & & & & & \\
\hline
\end{tabular}


The major structure along the east and northeast edge of the basin is inferred by gravity, seismic, and drill-hole data. Large differences in sediment thickness and lithology occur across the structure. Part of the structure is coincident with an earth fissure that displays vertical offset and has been named the Picacho Fault (Holzer and others, 1979). The structure lies between the Picacho Mountains and a deep test hole drilled by the Exxon Corporation (well 100, fig. 6), which penetrates more than 9,600 ft of basin sediments and volcanic rocks. Scarborough and Peirce (1978) estimated a maximum structural relief of $11,000 \mathrm{ft}$ between the test hole and the Picacho Mountains. Most of the structural relief probably is accommodated by a fault. A second significant structure trends northwest to southeast across the northern part of the basin and separates the deep basin to the south from shallow bedrock to the northeast. Eberley and Stanley (1978) interpreted the structure as a major basin fault zone in the Coolidge area from the seismic-reflection data.

Several other less significant structures are inferred by steep gravity gradients and drill-hole data. These structures are deeply buried or associated with small changes in sediment thickness; however, changes in lithologic facies occur within basin sediments near these structures. A northeastward- to southwestwardtrending structure is inferred from steep gravity gradients that extend from the west-central part of the basin to the Sawtooth Mountains (fig. 5). Lateral changes in lithology infer northwestward-trending structures in the southern part of the basin and along the west edge of the northern part of the basin. The gravity signature of the northwestward-trending structure along the northwest margin of the basin is obscured by an extensive 500- to 1,000-foot thickness of anhydrite. Anhydrite is much more dense than other basin sediments; therefore, large thicknesses of anhydrite result in comparatively higher gravity values. Another structure that trends northwestward across the basin west of Picacho Peak was suggested by Christie (1978) to explain an apparent decrease in sediment thickness to the south.

\section{Stratigraphy}

The sediments of Picacho Basin consist primarily of continental basin sediments that accumulated during the Cenozoic Era under restricted or closed drainage conditions. Fine sand, silt, clay, and evaporites were deposited in playas, or ephemeral lakes in topographic low regions. Areas around the topographic lows were dominated by alluvial deposition of interbedded sand, gravel, silt, and clay. Thick laterally continuous finegrained deposits of silt, clay, or evaporites that generally coincide with playa deposition are referred to in this report as playa facies. Laterally adjacent coarsegrained deposits of interbedded sand, gravel, silt, and clay are referred to as alluvial facies. Each stratigraphic unit contains both playa and alluvial facies. The playa facies and the greatest thickness of each unit generally are coincident with the basin graben. The alluvial facies generally occur near the basin margins where the units are thin.

The sediments of the basin are divided into lower, middle, and upper stratigraphic units. The units are divided on the basis of apparent water-bearing characteristics inferred from subsurface lithologic and physical-property information; therefore, these units are referred to as hydrostratigraphic units. The lower unit consists of an alluvial facies that is primarily conglomerate and a playa facies that includes mudstone and evaporites. The unit overlies bedrock throughout the basin and is as much as several thousand feet thick. The middle unit is composed largely of playa deposits and is as much as $1,500 \mathrm{ft}$ thick. The upper unit is primarily alluvial deposits of interbedded sand, gravel, silt, and clay that generally range in thickness from 500 to $1,500 \mathrm{ft}$.

This three-layer system of hydrostratigraphic units is similar to systems of units defined for hydrologic purposes in several basins in southern Arizona (fig. 7). Similar three-layer systems of units include the Fort Lowell Formation and upper and lower Tinaja beds in the Tucson Basin (Davidson, 1973) and Avra Valley (Anderson, 1989), the middle unit and upper and lower parts of the lower unit in the Salt River Valley area (Laney and Hahn, 1986; Brown and Pool, 1989), and the regional units of upper basin fill and upper and lower parts of lower basin fill of Pool (1986). These units may not be time correlative across the basins of southern Arizona, but tend to have similar stratigraphic characteristics and occur in similar structural positions.

Some investigators have divided the basin sediments in the Picacho Basin area into three units using classifications that are based on lithology (fig. 7). 


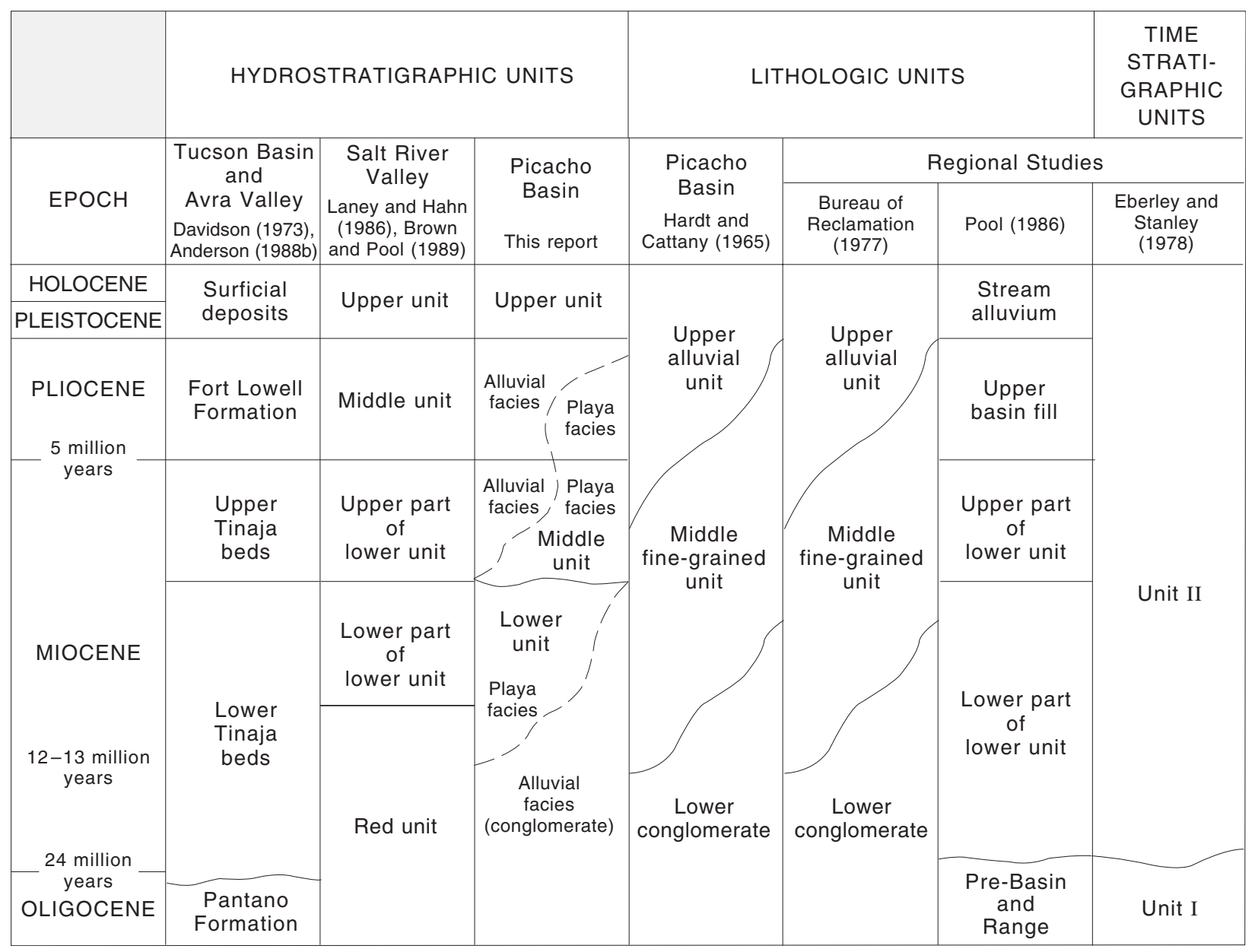

Figure 7. Correlation of local and regional basin sedimentary units.

The three common lithologic units include the lower conglomerate, middle fine-grained, and upper alluvial sediments (Hardt and Cattany, 1965; Bureau of Reclamation, 1977; Wickham and Corkhill, 1989). These lithologic units are different from the hydrostratigraphic units described in this report because lithologic boundaries do not necessarily coincide with significant variations in water-bearing properties. This difference is particularly important with respect to the large thickness of fine-grained sediments. Lithologic classifications assign these deposits to a single unit, but the hydrostratigraphic classification recognizes variations in water-bearing characteristics and assigns these deposits to more than one unit. Delineation of the water-bearing properties of the fine-grained sediments is important to this study because these properties greatly influence aquifer-system storage properties and subsidence of the land surface.

\section{Methods}

Description of the basin sediments required the integration of subsurface information that includes data from previous investigations of the geology and hydrogeology of the area, several types of logs from well drilling, and seismic surveys. The quality of information ranged from excellent core descriptions and geophysical logs to drillers' logs that are highly qualitative. The best descriptive information included laboratory tests of core porosity and density; detailed lithologic logs of core and drill cuttings; particle-size analysis; and geophysical logs of density, porosity, sonic velocity, and electrical resistivity. Much of this high-quality information, except for particle size, was obtained from exploratory wells drilled in the eastern part of the basin by the Bureau of Reclamation (BOR). Descriptions of the basin sediments are summarized in figure 8 and discussed in the following section. 


\begin{tabular}{|c|c|c|c|c|c|c|}
\hline \multirow{2}{*}{$\begin{array}{l}\text { HYDROSTRA- } \\
\text { TIGRAPHIC } \\
\text { UNIT }\end{array}$} & \multirow[t]{2}{*}{ LITHOLOGY } & \multicolumn{4}{|c|}{ PHYSICAL PROPERTIES } & \multirow{2}{*}{$\begin{array}{c}\text { HYDRO- } \\
\text { GEOLOGIC } \\
\text { UNIT }\end{array}$} \\
\hline & & $\begin{array}{c}\text { DENSITY, IN } \\
\text { GRAMS PER } \\
\text { CUBIC } \\
\text { CENTIMETER }\end{array}$ & POROSITY & $\begin{array}{l}\text { SEISMIC } \\
\text { VELOCITY, } \\
\text { IN FEET PER } \\
\text { SECOND }\end{array}$ & $\begin{array}{l}\text { PERCENT } \\
\text { FINE } \\
\text { GRAINED }\end{array}$ & \\
\hline & $\begin{array}{l}\text { Gila River } \\
\text { gravels }\end{array}$ & & & & & \multirow{8}{*}{$\begin{array}{l}\text { Upper } \\
\text { aquifer } \\
\text { system }\end{array}$} \\
\hline Upper unit & $\begin{array}{l}\text { Interbedded } \\
\text { sand and } \\
\quad \text { gravel } \\
\text { Silt, ? } \\
\text { clay, } \\
\text { and minor/ } \\
\text { gypsum? }\end{array}$ & 1.9 to 2.1 & 0.36 to 0.47 & $\begin{array}{c}\text { Greater } \\
\text { than } \\
7,200\end{array}$ & 20 to 70 & \\
\hline Middle unit & $\begin{array}{l}\text { Silt, }>\text { Silt, } \\
\text { clay, }>\text { clay, } \\
\text { mudstone, sand, } \\
\text { and } \quad \text { and } \\
\text { gypsum } 2 \text { gravel }\end{array}$ & \multirow{3}{*}{2.1 to 2.3} & \multirow{3}{*}{0.36 to 0.24} & \multirow{3}{*}{$\begin{array}{l}7,200 \\
\text { to } \\
8,200\end{array}$} & \multirow{3}{*}{20 to 90} & \\
\hline & \begin{tabular}{|c|} 
Basalt 7.9 \\
million years
\end{tabular} & & & & & \\
\hline & $\begin{array}{l}>\text { sand and } \\
>\text { gravel }\end{array}$ & & & & & \\
\hline Lower unit & 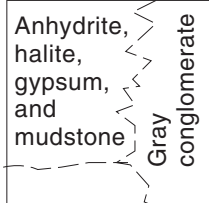 & 2.2 to 2.5 & $\begin{array}{l}\text { Less than } \\
0.23\end{array}$ & $\begin{array}{c}8,200 \\
\text { to } \\
15,000\end{array}$ & 70 to 100 & \\
\hline & $\begin{array}{l}\text { Red } \\
\text { conglomerate }\end{array}$ & & & & Less than 30 & \\
\hline Volcanics & $\begin{array}{l}\text { Intermediate } \\
\text { and silicic } \\
\text { volcanic rocks }\end{array}$ & $\begin{array}{c}\text { Not } \\
\text { applicable }\end{array}$ & $\begin{array}{c}\text { Not } \\
\text { applicable }\end{array}$ & $\begin{array}{c}11,500 \\
\text { to } \\
15,000\end{array}$ & $\begin{array}{c}\text { Not } \\
\text { applicable }\end{array}$ & \\
\hline Bedrock & $\begin{array}{l}\text { Granitic and } \\
\text { metamorphic } \\
\text { rocks }\end{array}$ & 2.67 & $\begin{array}{c}\text { Not } \\
\text { applicable }\end{array}$ & $\begin{array}{c}13,000 \\
\text { to } \\
20,000\end{array}$ & $\begin{array}{c}\text { Not } \\
\text { applicable }\end{array}$ & $\begin{array}{l}\text { Lower } \\
\text { confining } \\
\text { unit }\end{array}$ \\
\hline
\end{tabular}

Figure 8. Description of sedimentary units in Picacho Basin, Arizona.

The particle-size information and drill-cuttings descriptions were derived from analysis of drill cuttings. Analyses consisted of sample description and sieving of samples for percentage by weight of gravelsand and silt-clay fractions. Most analyses were done by the Arizona District of the U.S. Geological Survey (USGS) as part of ongoing data-collection activities or in cooperation with the BOR. Cuttings were obtained from drilling operations that used a variety of methods in drilling and sample collection. These differences influenced the amounts of fine-grained sediments that were retained. The information therefore can be used reliably only to estimate the vertical particle-size distribution at a well. Care was taken to eliminate samples that were biased through sample-collection methods. Cuttings originally were described by several individuals; therefore, additional descriptions of cuttings were done specifically for this study in order to provide consistent information.

More than 2,000 wells have been drilled in the basin, and most have drillers' logs. Some important changes in lithology normally are not described in drillers' logs but may be apparent in lithologic logs, drill cuttings, and geophysical logs. Lithologic changes that drillers' logs normally do not describe include variations in hardness or density, the presence of gypsum and other evaporites, and the difference between conglomerate and unconsolidated sand and 
gravel. Despite the inadequacies of drillers' logs, the logs can provide information on the distribution of fine-grained intervals and major changes in lithology especially in areas where better data are not available.

Information from 124 wells that included 53 drillers' logs was used to analyze basin sediments. Information from the remaining 71 wells consisted primarily of lithologic logs, particle-size analyses, and descriptions of drill cuttings. Information also included core descriptions and geophysical logs from many wells. Interpretations relied primarily on information from drill cuttings and geophysical logs. Selected drillers' logs were used as supplemental information in data-deficient areas and along geologic sections. The locations of wells with logs and seismic-refraction lines used in the construction of geologic sections and lines of geologic sections are shown in figure 6. The delineation of the spatial distribution of hydrostratigraphic units and facies within units is shown in figure 9.

\section{Lower Unit}

The lower unit consists of an alluvial facies of conglomerate and a playa facies of evaporites, sandstone, and mudstone. The conglomerate typically is red brown or red; evaporites are white to brown and contain some purple anhydrite. Conglomerate occurs near the surface on the basin periphery, and tens to hundreds of feet of conglomerate overlie bedrock throughout most of the basin. As much as several thousand feet of evaporites and mudstone occur in the graben. Geophysical logs and core and cuttings from well drilling indicate that bedding is indistinct in the conglomerate, but thin beds of fine-grained clastic material are common within the evaporite sequences. Vertical changes in lithology throughout the lower unit tend to occur gradually over intervals of tens or hundreds of feet. Although lithologies of overlying hydrostratigraphic units in the basin center are similar to those of the lower unit, generally silt and clay, the contact between the lower unit and overlying units typically is a distinct change in physical properties and possibly is an unconformity.

The conglomerate of the alluvial facies grades laterally from the basin margin into sandstone and evaporites of the playa facies within the basin graben. Conglomerate is interbedded extensively with and underlies anhydrite in the northern part of the basin. At well 73 (figs. 6 and 9, geologic section D-D'), several hundred feet of interbedded anhydrite and conglomerate are underlain by more than $3,000 \mathrm{ft}$ of sandstone and conglomerate. More than $600 \mathrm{ft}$ of conglomerate underlie anhydrite at well 54 (fig. 9, geologic section D-D'). The extent of the conglomerate at depth is unknown because of a lack of deep wells in the basin center; however, well data indicate that a conglomerate layer as much as several hundred feet thick is present along most of the margin of the basin. Two types of conglomerate, distinguished by clast type, are found in the basin. Conglomerate of granitic clasts occurs in the northern part of the basin, and conglomerate of volcanic clasts occurs in the southern part.

Several hundred to several thousand feet of lower-unit evaporites are found within the graben. The evaporite sequence consists of as much as several thousand feet of anhydrite with halite intervals near the top (fig. 9, geologic sections B-B', D-D', and D'-D"). The maximum continuous halite thickness of about $400 \mathrm{ft}$ occurs at well 73 (fig. 9, geologic section D-D'). Brown to red-brown mudstone of the lower unit occurs as thin, interbedded layers within the evaporites and as a massive unit as much as a few hundred feet thick near the top of the sequence. Greenish-gray to gray mudstone occurs near the top of the evaporites north and east of Eloy. Thin beds of evaporites of small areal extent can occur at the basin margins. Near Florence, a sequence of interbedded sandstone and gypsum occurs in a small northward- to southward-trending graben (Nason and others, 1982). The large accumulation of evaporites indicates that the lower unit was deposited in a closed drainage basin.

Lithologic information from several deep wells was used to describe the spatial distribution of evaporites in the lower unit (fig. 10). Anhydrite and (or) halite are known to occur in only eight wells, all of which are within the graben boundaries. Salty water and possible halite occurs in at least two other wells (68 and 110). The top of the evaporites in the lower unit is below sea level in most wells except in wells 73, 74, and 80 . The base of the evaporite sequence is defined by only five wells that are more than $3,000 \mathrm{ft}$ deep. The altitude of the base of the evaporites decreases toward well 100. The consistency of information with the interpreted structure indicates that the deepest part of the graben is south of well 100 (fig. 9, geologic section D'-D"). Large thicknesses of lower-unit evaporites probably are present at depth south of well 100 where the top of the evaporite sequence probably occurs below maximum well depths of about 2,500 ft. 


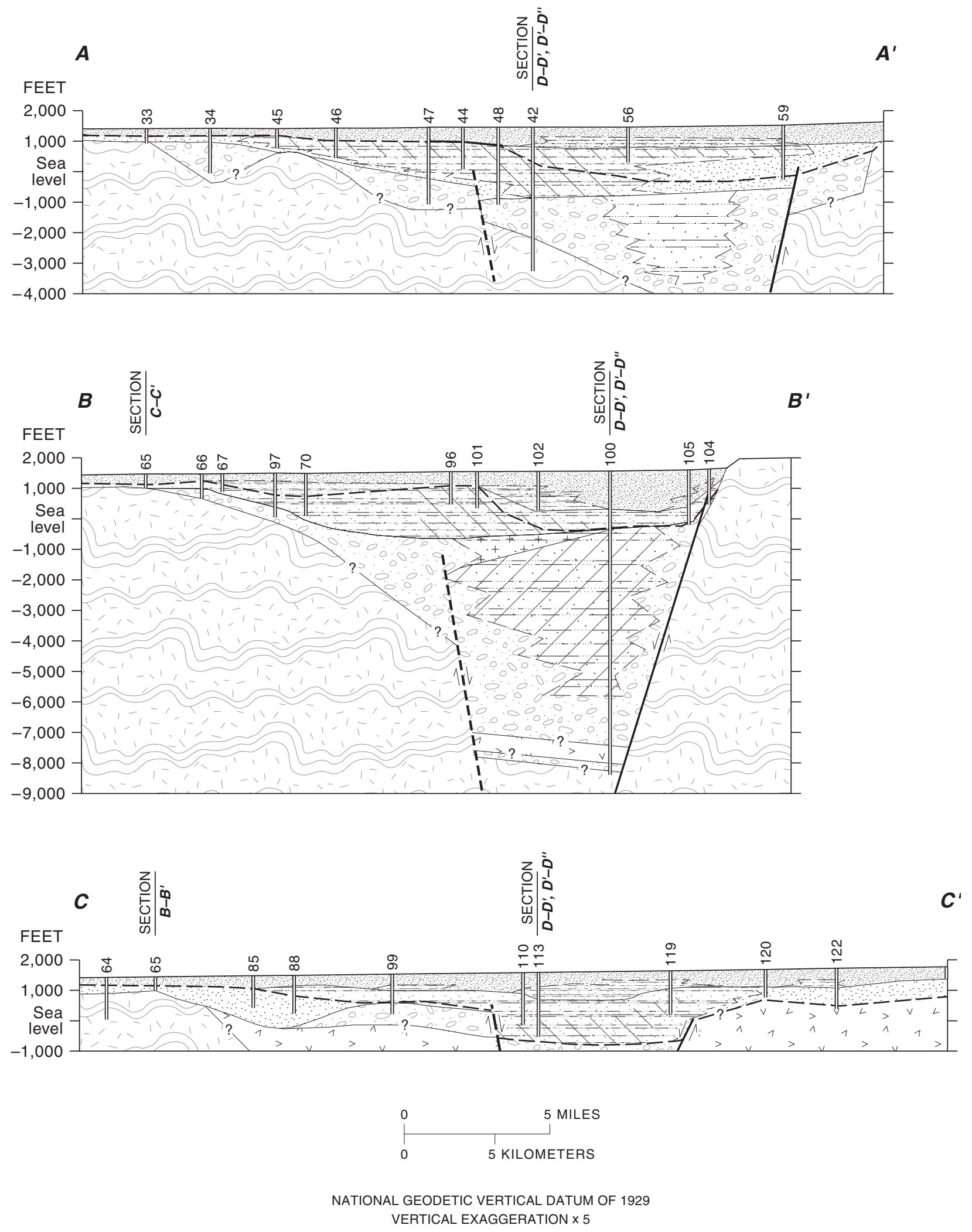

Figure 9. Geologic sections of Picacho Basin, Arizona. The locations of these sections are shown on figure 6. 


\section{D}
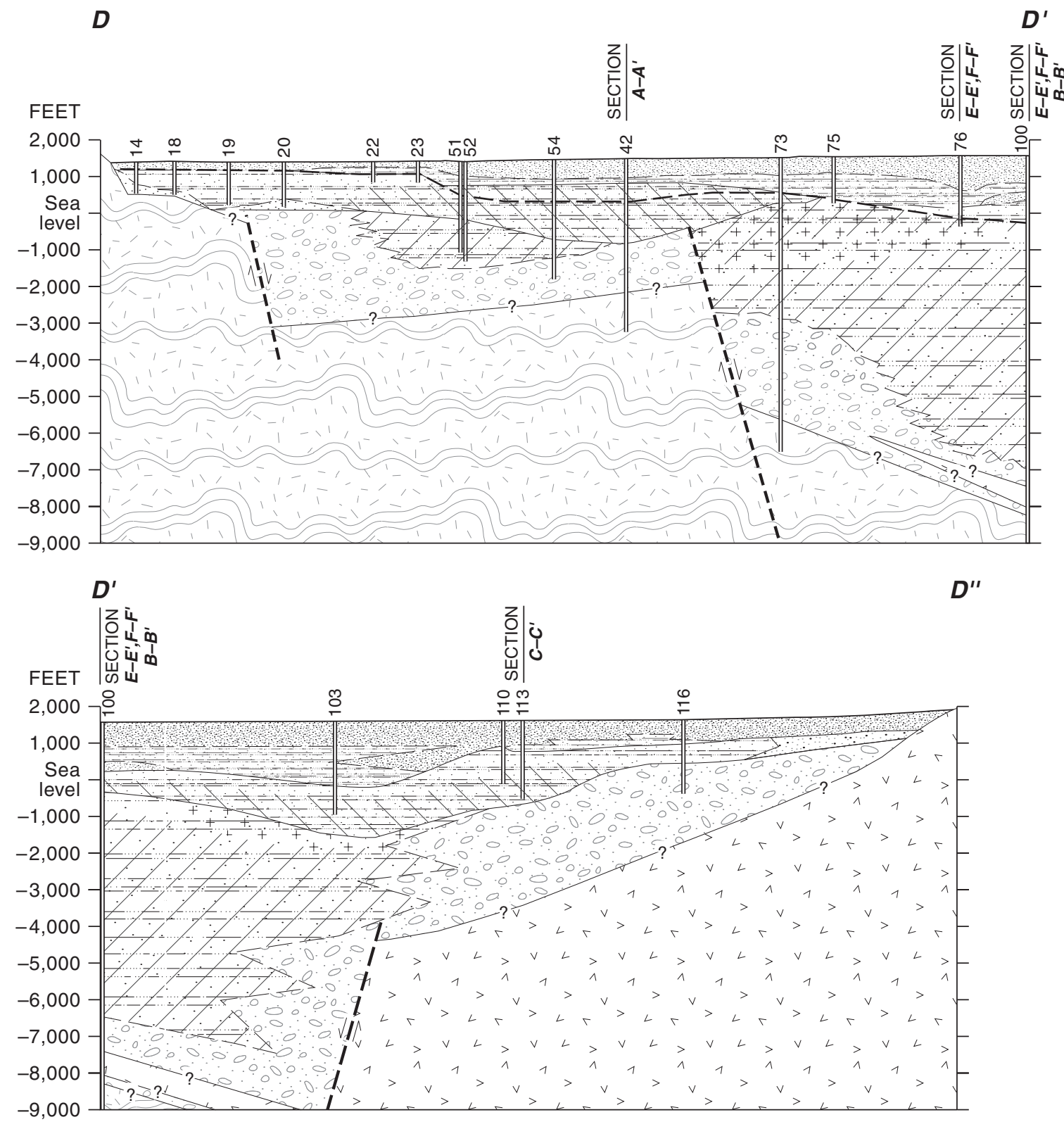

\section{EXPLANATION}

EVAPORITES

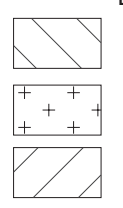

Gypsum

Halite

Anhydrite

CRYSTALLINE ROCK

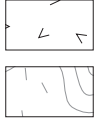

Volcanic rock

Granitic and metamorphic

rocks
UPPER UNIT

Alluvial facies

Playa facies

MIDDLE UNIT

Alluvial facies

Playa facies LOWER UNIT

Alluvial facies

Playa facies 


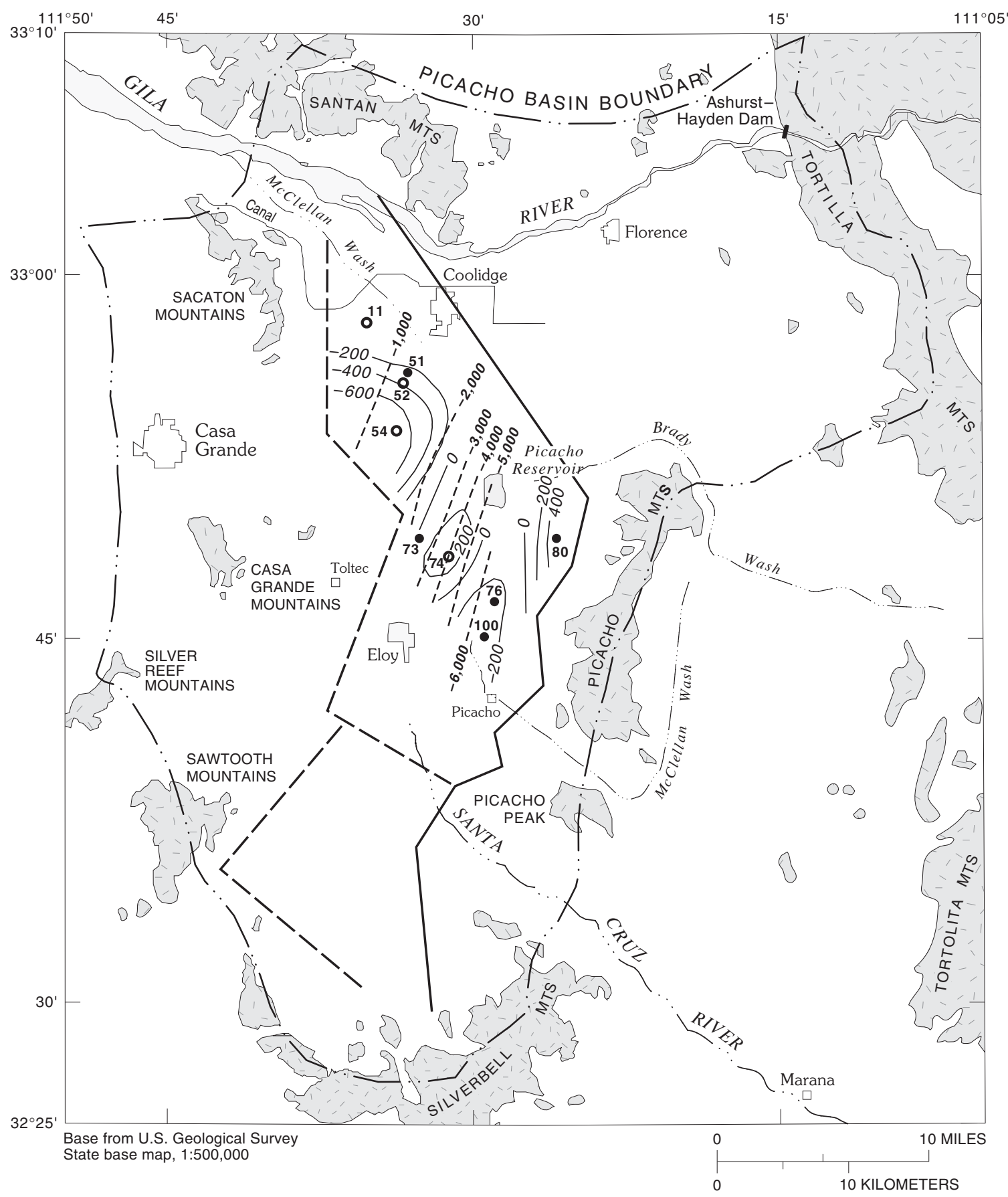

EXPLANATION

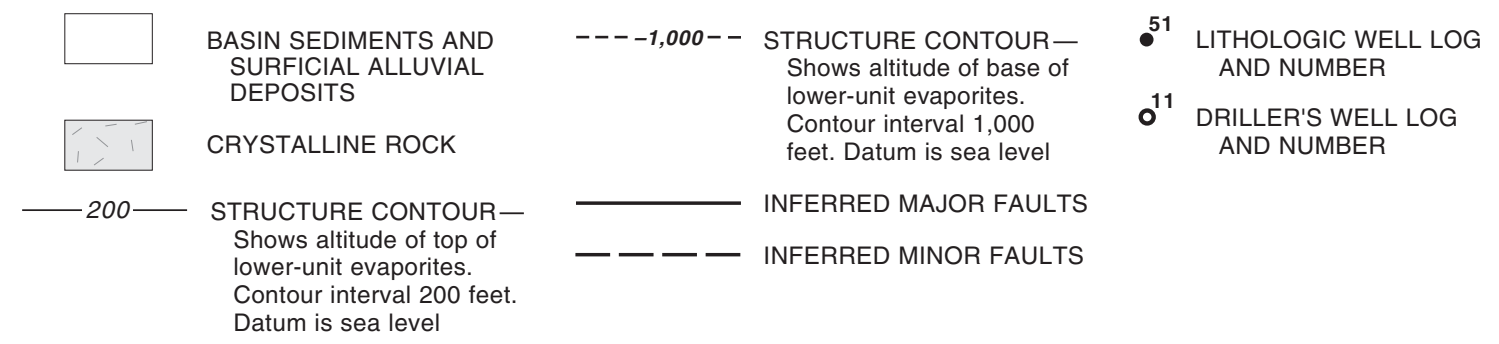

Figure 10. Structure contours of lower-unit evaporites, well logs, and faults in Picacho Basin, Arizona. 
The lower unit is correlative with several units described in other reports (fig. 7). Similar regional units have been recognized in the basins of Arizona by Eberley and Stanley (1978), BOR (1977), and Pool (1986). The lower unit is equivalent to the upper parts of Unit I and the lower part of Unit II of Eberley and Stanley (1978), the lower conglomerate and lower part of the middle fine-grained unit of BOR (1977), and the lower basin fill of Pool (1986). The lower part of the lower unit also may be equivalent to the red unit of the Salt River Valley (Laney and Hahn, 1986; Brown and Pool, 1989), Pantano Formation (Davidson, 1973; Anderson, 1988) and the pre-Basin and Range unit of Pool (1986). The lower unit is equivalent to the lower unit of Laney and Hahn (1986) and Brown and Pool (1988) in the Salt River Valley, which lies within the Gila Low north and west of the study area. The unit is equivalent to the lower conglomerate and lower part of the middle fine-grained unit of Hardt and Cattany (1965). The equivalent unit in the Tucson Basin and Avra Valley is the lower Tinaja beds described by Davidson (1973) and Anderson (1988, 1989).

\section{Middle Unit}

The middle unit comprises an alluvial facies and a playa facies that include large thicknesses of gypsum. Alluvial facies of interbedded sand, gravel, silt, and clay occur mainly along the basin margins and generally are a few hundred feet thick. Coarse-grained sediments of the alluvial facies typically are brown to gray-brown. The playa facies, which includes silt, clay, mudstone, and gypsum, occurs throughout a large area of the basin. Fine-grained sediments of the playa facies typically are brown or red-brown; however, some gray and greenish-gray clays and silts occur northeast of Eloy. Fifty percent or more of the fine-grained sediments at the top of the unit in core from well 77 consist of the clay mineral, montmorillonite (fig. 6).

Data from geophysical logs and well cuttings indicate that the top of the playa facies commonly includes sand and gravel interbeds that are 5 to $10 \mathrm{ft}$ thick. The frequency and thickness of the sand and gravel interbeds decrease with depth. Several hundred feet of gypsum occur in the northern part of the basin (fig. 9, geologic sections A-A' and D-D'). Alluvial deposits of the unit underlie much of the playa deposits in the northern and southwestern parts of the basin (fig. 9, geologic sections $\mathrm{A}-\mathrm{A}^{\prime}$ and $\mathrm{C}-\mathrm{C}^{\prime}$ ), but playa deposits of the middle unit directly overlie the lower unit in several wells (fig. 9, geologic sections A-A', B-B', and D-D').

Lithologic information from several wells was used to describe the spatial distribution of the gypsum deposits in the middle unit (fig. 11). Massive gypsum mainly is within the graben boundaries. Thin beds and disseminated gypsum are common near the top of the evaporite sequence and outside the graben boundaries. The base of the gypsum deposits is at more than $500 \mathrm{ft}$ below sea level in three wells in the northern part of the basin. The lowest altitude of the top of the gypsum deposits is below sea level at well 100. The highest altitude is above $1,000 \mathrm{ft}$ in the extreme northern part of the basin. The largest beds of massive gypsum, more than 1,000 $\mathrm{ft}$ thick, are in the northwestern part of the graben. The concentration of middle-unit gypsum along the northwest margins of the graben probably was caused by an influx of sediment from higher altitudes to the east and southeast of the basin.

The large extent of the playa facies and occurrence of thick gypsum deposits indicate that a closed-basin depositional environment was predominant during accumulation of the middle unit. The decreased frequency of sand and gravel interbeds with depth, however, indicates that transition to a through-flowing drainage probably occurred during deposition of the upper part of the unit.

Age of the middle unit is determined by basalt flows that are dated at 7.9 m.y.B.P. (Nason and others, 1982) and a palynological age of Pliocene for an extensive clay layer within poorly indurated alluvial deposits of the unit at Poston Butte near Florence. The middle unit is correlative with the upper part of the lower unit of Laney and Hahn (1986) and Brown and Pool (1988) in the Salt River Valley and part of the middle fine-grained unit and lower part of the upper alluvial unit of Hardt and Cattany (1965).

The equivalent unit in the Tucson Basin and Avra Valley is the upper Tinaja beds described by Davidson (1973) and Anderson (1988, 1989). The middle unit is equivalent to the lower part of Unit II of Eberley and Stanley (1978), part of the middle fine-grained unit and the lower part of the upper alluvial unit of BOR (1977), and the upper part of the lower basin fill of Pool (1986). 


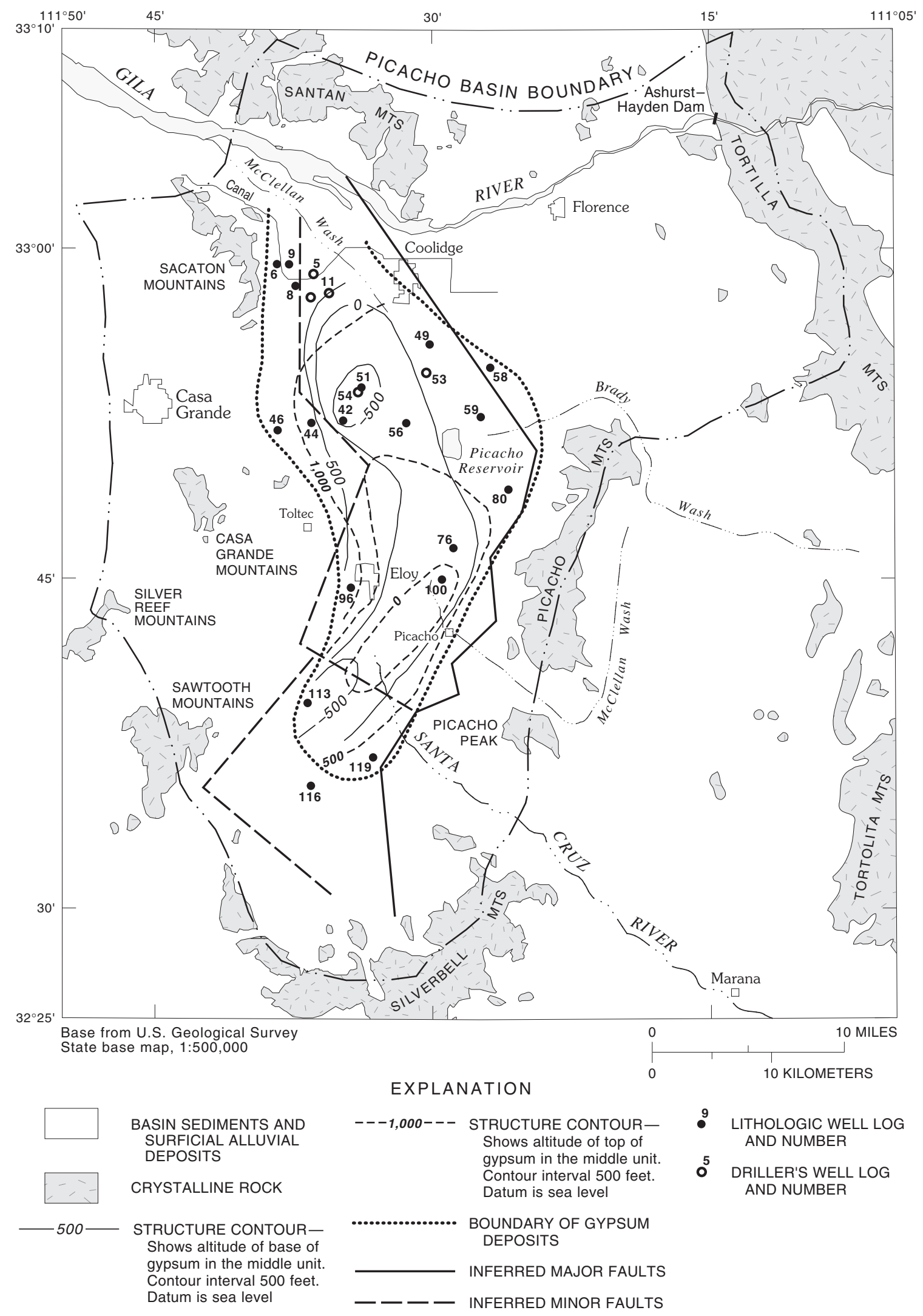

Figure 11. Distribution of middle-unit gypsum deposits in Picacho Basin, Arizona. 


\section{Upper Unit}

The upper unit consists mainly of alluvial deposits of interbedded sand, gravel, silt, and clay. The unit includes local playa facies of silt and clay and recent deposits of the Gila and Santa Cruz Rivers. The unit typically is 500 to $1,000 \mathrm{ft}$ thick but may be as much as 1,500 to $2,000 \mathrm{ft}$ thick in the eastern part of the basin (fig. 9, geologic sections B-B', and D-D'). The sediments typically are brown to gray brown. Individual beds are about 10 to $50 \mathrm{ft}$ thick.

The upper $500 \mathrm{ft}$ of the unit consists of interbedded sand, gravel, silt, and clay and contain about 50 percent silt and clay. The unit tends to become finer grained with depth and contains local playa facies, which occur mainly at the base of the unit and may be several hundred feet thick near Eloy (figs. 6 and 9, geologic sections B-B' and D-D'). Lakebed deposits of blue-green clay near the base of the unit in the northwestern part of the basin have been recorded in drillers' logs. At well 77, montmorillonite composes 50 percent or more of the fine-grained sediments.

The upper unit includes alluvial deposits of the Gila and Santa Cruz Rivers. Deposits of sand, gravel, and boulders of the Gila River occur within the present flood plain, on adjacent terraces, and adjacent to the Sacaton Mountains. Well data indicate a maximum thickness of about $100 \mathrm{ft}$ for these deposits, although thicknesses typically are less than $50 \mathrm{ft}$. Recent fluvial deposits of 50 to $70 \mathrm{ft}$ in thickness occur near the river about 2 mi northwest of Florence (Nason and others, 1982). Alluvial deposits associated with the Santa Cruz River are difficult to distinguish from the underlying alluvial deposits of the upper unit. Data are insufficient to map adequately the distribution of the Gila and Santa Cruz River deposits; therefore, both are included with the upper unit.

The upper unit is conformable with the middle unit; changes in lithology between the two units are gradational over intervals of as much as $200 \mathrm{ft}$. Playa deposits of the upper unit are distinguished from playa deposits of the middle unit by a greater frequency of coarse-grained beds, lower density and sonic velocity, greater porosity, and higher electrical resistivity. Alluvial deposits of the middle and upper units are similar and are difficult to distinguish without geophysical and lithologic logs. Where the upper unit is thickest, along the east margins of the basin and south of Eloy, the lower part may be equivalent depositionally to deposits mapped as the playa facies of the middle unit that occur at similar altitudes to the west, north, and south (fig. 9, geologic section A-A', B-B', and D'-D"). These sediments have been placed in the upper unit because of low density and sonic velocity, high porosity, and lack of induration. More reliable correlation of sediments across these areas requires additional geophysical logs and lithologic information or seismic data in the western and central parts of the basin.

Most of the upper unit was deposited under conditions of through-flowing drainage with local areas of restricted drainage. Conditions probably were similar to the present drainage, which is an alluvial plain of low relief. A locally thick playa facies in the east-central part of the basin probably resulted from natural compaction of underlying sediments, which formed a small region of closed drainage. Later development of integrated drainage along the Gila River drainage system resulted in erosion of the upper unit in the northern part of the basin and deposition of stream and terrace gravels near the river. Depositional conditions in the southern part of the basin did not change significantly after the development of the Gila River drainage. Sediment from the Santa Cruz drainage was deposited across an alluvial fan of low relief that grades into an alluvial plain in the central part of the basin.

Volcanic units or fossils that could be dated to determine the age of the upper unit are not present; however, the age can be inferred by correlation with similar units in nearby areas. The unit contains internal drainage deposits near the base and regionally integrated drainage deposits near the top. The development of regionally integrated drainage along the Salt River occurred prior to 3 m.y.B.P. (Shafiqullah and others, 1980). The small thickness and extent of Gila River deposits in Picacho Basin compared to the much thicker and extensive Salt River deposits that are more than $400 \mathrm{ft}$ thick in the Salt River Valley (Laney and Hahn, 1986; Brown and Pool, 1989) indicate that the through-flowing Gila River may have developed later than the through-flowing Salt River. The upper $500 \mathrm{ft}$ of the upper unit in Picacho Basin can be considered to have been deposited during a period of regionally integrated drainage deposits because no significant fine- grained facies occur; therefore, most of the unit is younger than 3 m.y.

The upper unit is equivalent to the middle and upper units of Laney and Hahn (1986) and Brown and Pool (1988) in the Salt River Valley and to the upper 
alluvial unit of Hardt and Cattany (1965).

The equivalent unit in the Tucson Basin and Avra Valley is the Fort Lowell Formation and terrace deposits described by Davidson (1973) and Anderson (1988, 1989). Regionally, the unit is equivalent to the upper part of Unit II of Eberley and Stanley (1978), the upper alluvial unit of BOR (1977), and the upper basin-fill and stream deposits of Pool (1986).

\section{Physical Properties}

Each hydrostratigraphic unit of the basin has characteristic physical properties. Physical properties for which data are available include particle size, density, porosity, seismic or sonic velocity, and compressibility. Much of the data are derived from borehole information in the east half of the basin including particle-size analysis of cuttings, geophysical $\operatorname{logs}$, laboratory tests on core, and seismic-refraction information. These data are limited in number and areal extent but indicate significant differences in physical properties of units.

Particle Size.-Particle-size distribution from well cuttings was used to describe each unit and delineate the extent of alluvial and playa facies within each unit. Drillers' or lithologic logs also were used as supplemental data to map the extent of each facies. Alluvial facies generally contain less than 60 percent silt and clay. Playa facies generally contain more than 60 percent silt- and clay-sized particles. Zones of more than 60 percent silt and clay that cannot be traced laterally between several wells were considered to be localized fine-grained beds within the alluvial facies.

In general, the basin sediments become increasingly fine grained with depth in the basin center and increasingly coarse grained with depth on the basin margin. Fewer sand and gravel lenses occur with depth in the basin center where alluvial deposits of the upper unit gradationally overlie playa deposits of the upper, middle, and lower units. Increasing amounts of sand, gravel, and conglomerate occur with depth on the basin margins where alluvial deposits of the upper and middle units overlie conglomerate of the lower unit.

Average particle size of cuttings from the upper unit generally ranges from 20 to 70 percent silt and clay (fig. 8). The greatest concentration of silt and clay occurs in the center of the basin where both alluvial and playa facies are penetrated by wells. Silt and clay content of less than 40 percent occurs only in small areas at the basin margins, such as where the unit includes Gila River deposits. Average particle-size distribution in the middle unit ranges from 20 to 90 percent silt and clay (fig. 8). The average percentage of silt and clay for the playa facies of the middle unit is as much as 70 to 90 percent. The few particle-size data available for the playa facies of the lower unit indicate that it contains fewer sand and gravel lenses and a greater percentage of silt and clay than the playa facies of the middle unit. Conglomerate of the lower unit generally contains less than 30 percent silt and clay (fig. 8).

Density.-Typical density variations within the upper 2,000 ft of sediments are shown in a geologic section with gamma-gamma density logs from four wells on the east margin of the basin (fig. 12). Density of the sediments in the upper and middle units generally ranges from 1.9 to $2.1 \mathrm{~g} / \mathrm{cm}^{3}$ (grams per cubic centimeter) and 2.1 to $2.3 \mathrm{~g} / \mathrm{cm}^{3}$, respectively (fig. 8). In both units, density gradually increases with depth near the basin margin (wells 104 and 105) and is nearly uniform with depth near the basin center (well 100). Density generally increases from the basin center toward the basin margin in the middle unit. Density of the sediments in the lower unit ranges from 2.2 to $2.5 \mathrm{~g} / \mathrm{cm}^{3}$; however, available data indicates that the density of most of the unit is greater than $2.3 \mathrm{~g} / \mathrm{cm}^{3}$ (fig. 8). The density ranges from 2.3 to $2.5 \mathrm{~g} / \mathrm{cm}^{3}$ for the conglomerate, is close to $2.3 \mathrm{~g} / \mathrm{cm}^{3}$ for the mudstones, and can range from 2.1 to $2.9 \mathrm{~g} / \mathrm{cm}^{3}$ for the evaporites. Halite, gypsum, and anhydrite have densities of $2.16,2.32$, and $2.9 \mathrm{~g} / \mathrm{cm}^{3}$, respectively (Dana, 1965). The upper $100 \mathrm{ft}$ of the lower unit in well 100 contains interbedded mudstone and anhydrite that have a density of about $2.5 \mathrm{~g} / \mathrm{cm}^{3}$.

The thickness of low-density deposits in Picacho Basin is large compared with similar deposits in three other basins (fig. 13). Tucci and others (1982) conducted borehole-gravity surveys of several wells in central and southern Arizona and calculated basin-fill densities. These determinations indicated that densities of $2.1 \mathrm{~g} / \mathrm{cm}^{3}$ or less did not occur below depths of about $400 \mathrm{ft}$, and densities of $2.2 \mathrm{~g} / \mathrm{cm}^{3}$ or less occurred below about $800 \mathrm{ft}$ in only one well. In Picacho Basin, sediments of less than $2.1 \mathrm{~g} / \mathrm{cm}^{3}$ occur to a depth of more than $1,700 \mathrm{ft}$. 
DENSITY SECTION — Value of density log, in grams per cubic centimeter

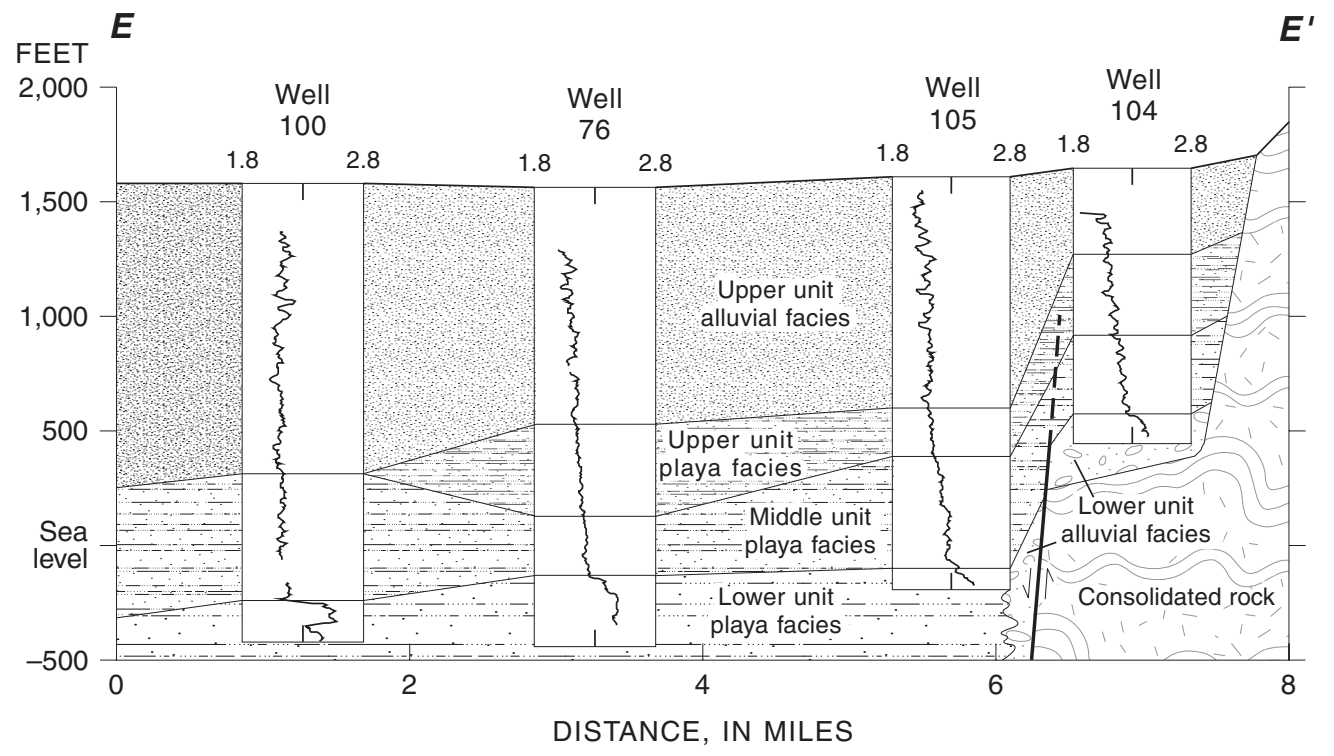

SONIC-VELOCITY SECTION —Value of velocity log, in feet per second

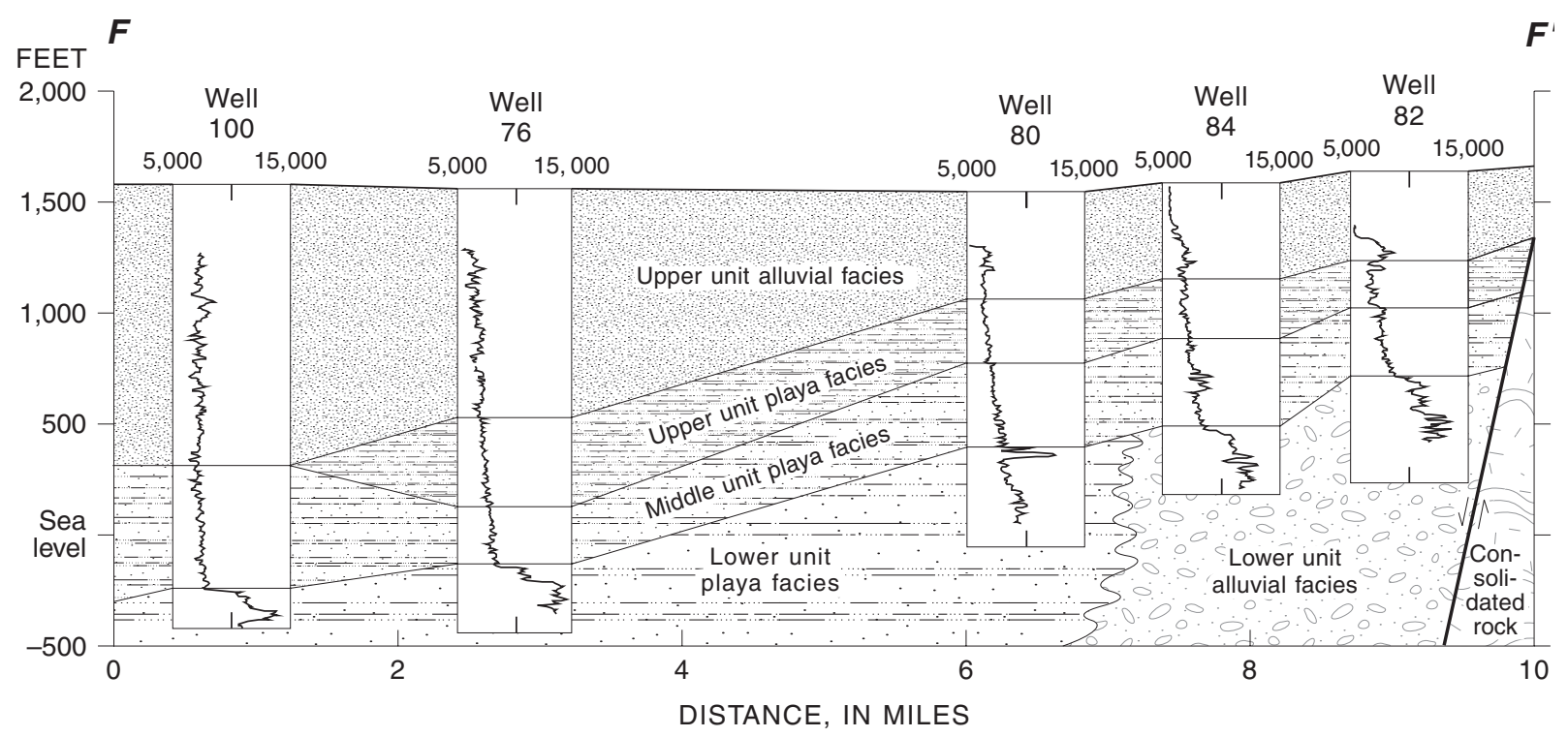

Figure 12. Density and sonic velocity of sediments in Picacho Basin, Arizona. 


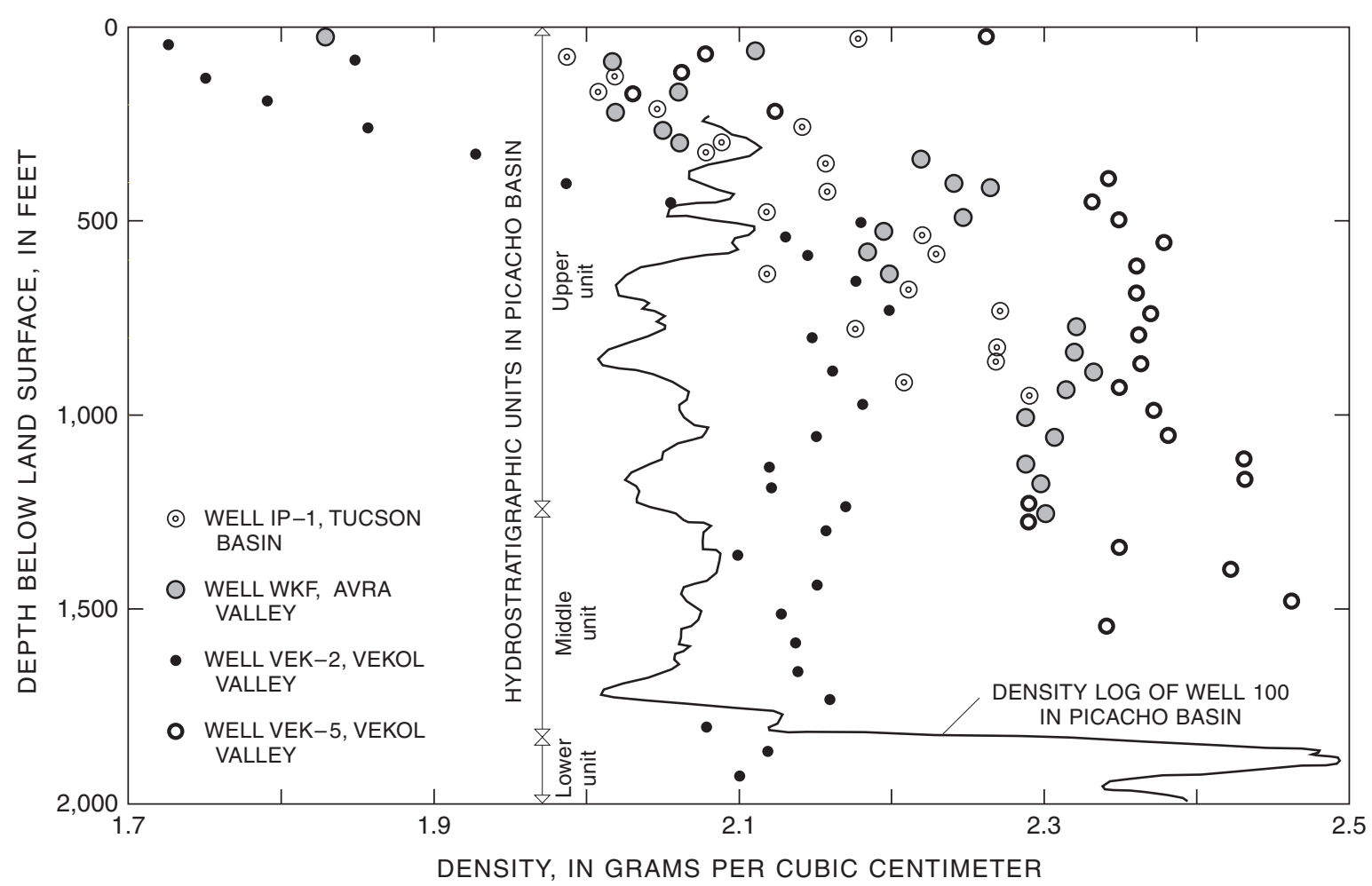

Figure 13. Density of basin sediments in the Basin and Range physiographic province of Arizona (modified from Tuccii and others, 1982).

Sonic Velocity.-The vertical and lateral trends in sonic velocities are similar to density trends (fig. 12). Sonic velocities generally are less than $7,200 \mathrm{ft} / \mathrm{s}$ in the upper unit, 7,200 to $8,200 \mathrm{ft} / \mathrm{s}$ in the middle unit, and 8,200 to $15,000 \mathrm{ft} / \mathrm{s}$ in the lower unit (fig. 8). Velocities tend to increase gradually with depth in the middle and upper units except in well 100. A greater percentage of silt and clay at depth in well 100 and corresponding increased porosity could cause a lack of increased velocity and density with depth in comparison with other wells on the section. The contact between the middle and lower unit generally is a significant velocity break. Surface seismic-refraction information also indicates that refraction velocities increase from less than $7,200 \mathrm{ft} / \mathrm{s}$ in the upper and middle units to more than $8,200 \mathrm{ft} / \mathrm{s}$ in the lower unit.

Porosity-Porosity generally is inversely related to sediment density. This correlation is supported by data from neutron logs at several drill holes in Picacho Basin. Porosity can be estimated from density information by using the following equation:

$$
\phi=\frac{\left(\rho_{g}-\rho\right)}{\left(\rho_{g}-\rho_{f}\right)},
$$

where

$$
\begin{aligned}
\phi & =\text { porosity } \\
\rho_{g} & =\text { average grain density } \\
\rho & =\text { measured density, and } \\
\rho_{\phi} & =\text { fluid density. }
\end{aligned}
$$

Ranges of porosity values for units were calculated by using an average grain density of $2.72 \mathrm{~g} / \mathrm{cm}^{3}$ measured from core samples from well 77, a fluid density of $1.0 \mathrm{~g} / \mathrm{cm}^{3}$, and density values from gammagamma density logs. Porosity was determined to range from 0.47 to 0.36 for the upper unit, 0.36 to 0.24 for the middle unit, and less than 0.30 for the lower unit (fig. 8); porosity in the lower unit generally is less than 0.25 . Porosity values calculated from density logs of the upper unit correspond well with the measured density and porosity of core from the upper unit at well 77 , which contained densities that range from 1.91 to $2.05 \mathrm{~g} / \mathrm{cm}^{3}$ and porosities that range from 0.47 to 0.38 .

Compressibility.-Compressibility is the ability of a medium to change volume in response to an applied stress. This discussion refers to the compressibility of fine-grained sediments because fine-grained sediments 
are more susceptible than coarse-grained sediments to compression. The two types of compressibility are elastic, which is recoverable, and inelastic, which is not recoverable. The compressibility of a medium can be described using the compression index $\left(C_{c}\right)$, which is the rate of change of void ratio divided by the difference between the logarithm of the applied stress and logarithm of initial stress (Jorgensen, 1980).

Inelastic-compressibility information is available as $C_{c}$ from lab tests on eight core samples of sandy clay from well 77 (fig. 6). Seven of the samples were from the upper unit, and one was from the middle unit. Values of $C_{c}$ ranged from 0.34 to 0.51 with values increasing with greater porosity and lower density (Thomas L. Holzer, USGS, written commun., date unknown). Porosity and compressibility of the one sample from the playa facies of the middle unit were 0.45 and 0.72 , respectively. The larger value of compressibility in the middle unit probably resulted from a larger percentage of montmorillonite clays.

Additional direct measurements that could indicate the difference in compressibility of the units are not available. Some basic differences in compressibility in each unit, however, can be inferred from the density of fine-grained sediments. The inference requires that the sediments in each unit consist of assemblages of minerals that deform similarly under an applied load. The results of compression tests of core from well 77 indicate that density increases with decreasing porosity and with a decreasing $C_{c}$. The much lower values of density and the larger porosity in the fine-grained sediments of the middle and upper units in relation to those of the lower unit indicate that the middle and upper units contain much more void space available for compression and also are more compressible than the lower unit. Density for most of the lower unit is greater than $2.3 \mathrm{~g} / \mathrm{cm}^{3}$ and most porosities are less than 0.25 ; therefore, the lower unit probably is incompressible in comparison with the upper and middle units.

Additional qualitative information on compressibility is available from drillers' logs, lithologic logs, and drill cuttings. Dense fine-grained sediments commonly are described in drillers' logs with the use of modifiers, such as "hardpan," indicating a much more resistant unit. Lithologic logs indicate more dense or indurated fine-grained sediments through descriptors such as mudstone, siltstone, or claystone. Drill cuttings of more dense fine-grained sediments typically return to the surface as chips of mudstone rather than as clay balls or individual grains disseminated within the drilling fluid. The amount of dense fine-grained sediments generally increases with depth in the middle unit. The approximate transition from low-density to high-density fine-grained sediments was estimated from various types of logs and is shown on the geologic sections (fig. 9) as the base of highly compressible sediments. Most of the middle unit playa facies in the western part of the basin consist of dense sediments, but $500 \mathrm{ft}$ to more than $1,000 \mathrm{ft}$ of low-density and more compressible sediments are present in the eastern and southern parts of the basin.

\section{Structure of the Basin Sediments}

Structure of the basin sediments was determined from outcrops, well core, geologic information from surface and subsurface mines, and one dip-meter log of well 100, which is the deepest hole in the basin (figs. 6 and 9, geologic sections $\mathrm{B}-\mathrm{B}^{\prime}$ and $\left.\mathrm{D}-\mathrm{D}^{\prime}\right)$. In general, deformation of the basin sediments increases with depth. The greatest degree of structural deformation occurs in older sediments that are faulted and tilted through listric normal faulting. Sediments also may be faulted extensively by high-angle normal faults near the main basin structures (fig. 5).

Much of the lower unit is disturbed structurally by normal faults, and the degree of deformation increases with depth. The dip-meter log of well 100 indicates that the sediments of the lower unit dip in a westerly direction (figs. 6 and 9, geologic sections B-B' and D-D'). Dip increases from less than $5^{\circ}$ above $4,000 \mathrm{ft}$ to as much as $15^{\circ}$ between 4,000 and 8,200 ft (T.B. Stanley, geologist, Exxon Company, U.S.A., written commun., 1973). Increased tilting with depth near the fault is expected because of a greater degree of offset with depth and closer proximity to the fault. Offset occurs at the surface but generally is considered to be a result of differential compaction within the aquifer system across the fault (Holzer and others, 1979).

Older deposits of the lower unit are faulted extensively and are tilted by listric normal faults. Conglomerate at the Sacaton Mine near Casa Grande is faulted extensively and tilted toward the northeast (Cummings, 1982). Steeply tilted interbedded sandstone and gypsum occurs near Florence (Nason and others, 1982).

The middle unit may be deformed structurally near the major normal faults in the basin (fig. 5). Changes in altitude and thickness of the middle unit may be caused by dislocation and (or) draping across faults that bound 
the graben north of Eloy (fig. 9, geologic sections A-A'), near Eloy (fig. 9, geologic section B-B'), and several miles south of Eloy (fig. 9, geologic sections $\mathrm{C}-\mathrm{C}^{\prime}$ and $\left.\mathrm{D}-\mathrm{D}^{\prime}\right)$. Location of the greatest thickness of the middle unit adjacent to the west- and south-bounding graben faults (fig. 9, geologic sections $\mathrm{A}-\mathrm{A}^{\prime}, \mathrm{B}-\mathrm{B}^{\prime}, \mathrm{C}-\mathrm{C}^{\prime}$, and D-D") indicates displacement along those faults during deposition of the unit. The altitude of the top of the middle unit generally conforms to the shape of the graben. Higher altitudes of the unit adjacent to the Picacho Mountains (fig. 9, geologic section B-B') may be caused by dislocation along the fault or draping of the unit across the Picacho Fault. The top of the unit is found at lower altitudes on the east margins of the basin and in the low-gravity region south of Eloy.

The upper unit generally is flat lying but may be deformed near the major graben-bounding faults (fig. 5). A potential for deformation near major structures is indicated by large changes in thickness of the upper unit in those areas. Surface displacement of the upper unit has been caused by differential compaction within the aquifer system across the Picacho Fault (Holzer and others, 1979). Displacement and tilting of the unit in the subsurface near major structures, such as the Picacho Fault, however, cannot be detected using available data.

Structure of the basin and basin sediments indicates that the formation of the depositional basin is related to regional extension and listric normal faulting of upper-plate rocks. The basin occurs as a structural low between upper- and lower-plate rocks. The largest thickness of the lower unit and greatest accumulation of evaporites occurs adjacent to the detachment fault where the most structural relief would be expected. Similarities in deformation of upper-plate rocks and sediments near the base of the lower unit support an interpretation of continued low-angle listric normal faulting during the initial stages of basin formation. High-angle normal faulting that typically is associated with the Basin and Range structural disturbance occurred at a later stage during deposition of the upper part of the lower unit and younger sediments.

\section{HYDROLOGY}

\section{Streams}

Major streams of the area are sources of recharge to the ground-water system. Ground-water discharge also occurs near streams where the water table intersects the streambed. Most streams in the basin are ephemeral and carry only small quantities of water in response to local rainfall. The Gila River is a major stream draining 18,000 mi ${ }^{2}$ of southern Arizona and parts of western New Mexico (fig. 1). Other significant streams include McClellan Wash and the Santa Cruz River. McClellan Wash and its tributaries drain the northern half of the basin and an area east of the Picacho Mountains to the Gila River. Flow in the wash and ground-water recharge occur in response to local precipitation. The Santa Cruz River drains a large region of southeastern Arizona and enters the basin between Picacho Peak and the Silverbell Mountains. Flows in the Santa Cruz River occur in response to local precipitation and intense precipitation to the southeast.

Natural conditions of flow in the Gila River have been altered by regulation and diversion of flow for crop irrigation upstream from and in Picacho Basin. Natural conditions of flow in the Santa Cruz River also have been altered by diversions for irrigation.

The distribution of recharge from these two streams has changed because of the streamflow regulation and the redistribution of water from the original stream channel to irrigated lands.

\section{Predevelopment}

The Gila River was perennial in part of the study area before diversion of water for irrigation; however, no streamflow records exist for the period before diversions. Natural conditions of flow can be estimated only from measurements and accounts of conditions of flow during early development.

The earliest accounts of diversions of Gila River flow include diversions before the late 1800 s by Indians for the irrigation of about 14,000 acres in an area that included the flood plain within the western part of the study area (Davis, 1897b). Later upstream diversions included 60,000 acre-ft/yr or more before 1900 (Thomsen and Eychaner, 1991), which reduced base flow during the growing season by as much as a few hundred cubic feet per second.

Conditions of flow before upstream diversions of Gila River flow are unknown. Lee (1904) provided an account of conditions near Coolidge in the early part of the century. The channel was dry east of Coolidge, but water returned to the river from the subsurface near Coolidge and flowed in a stream of several cubic feet per second; the quantity of water varied with the season. Flow continued on the surface for several miles through a region of swamps and sloughs that contained water year round. Periodic flow also occurred where the river enters the basin at Toltec Buttes about $14 \mathrm{mi}$ 
upstream from Florence (fig. 2). Records of daily flows from 1889 to 1896 (Lippincott, 1900) indicate that flow at Toltec Buttes was 0 to $1,000 \mathrm{ft}^{3} / \mathrm{s}$ during most of the year, and peaks of 2,000 to $12,000 \mathrm{ft}^{3} / \mathrm{s}$ occurred during summer and winter months. Peak flows were more frequent during the summer than during the winter.

These early accounts indicate that parts the Gila River were major areas of recharge and discharge during the late 1800s. Base flow at Toltec Buttes infiltrated through the streambed or evaporated before reaching the Coolidge area. Infiltration and recharge probably were much larger during large flows. Discharge of shallow ground water to the streambed and evapotranspiration occurred in the area west of Coolidge. Natural perennial flow did not occur in the reach upstream from Coolidge at the time of Lee's (1904) account, but perennial flow could have been present at an earlier time.

Flow in the Santa Cruz River is a minor source of ground-water recharge in the southern part of the basin. Discharge of ground water through seepage to the Santa Cruz River is not known to have occurred before development. Streamflow losses in the basin cannot be estimated because of a lack of quantitative information. Accounts of postdevelopment flows provide the only information with which to evaluate predevelopment infiltration of flow in the Santa Cruz River. Flows rarely have been large enough to result in continuous flow across the basin. Only three flows-in 1939, 1962, and 1983 - are known to have traversed the basin (Smith, 1940; J.L. Betancourt, hydrologist, USGS, oral commun., 1988). Prior to 1941, flow in the river would disperse across the cultivated flood plain south of Picacho Peak (Turner and others, 1943), and large infrequent flows would spread across the surface of a large alluvial fan south and west of Eloy where the river channel becomes indistinct (Smith, 1940). Smith (1940) estimated that flow into the Eloy area in August 1939 resulted in no more than a good application of irrigation water and could have resulted in a reduction of ground-water withdrawals for irrigation by about 2,000 acre-ft.

\section{Postdevelopment}

Diversions of Gila River flow in the basin became significant with the construction of canals in 1887 for irrigation of less than 7,000 acres. The canals originally diverted water several miles to the south of Florence. By 1889, water was diverted as far as Casa Grande. Alteration of natural flows in the Gila River continued with the construction of Ashurst-Hayden Dam in 1922 at the head of the Florence-Casa Grande Canal (fig. 2). The San Carlos Irrigation Project was authorized by Congress in 1924 (Turner and others, 1943) to distribute irrigation water to Indian and non-Indian lands along the Gila River including the northern part of Picacho Basin. In 1928, flow of the Gila River was further regulated with the completion of Coolidge Dam and San Carlos Reservoir about 65 mi upstream from Florence. Unregulated flows of the San Pedro River enter the Gila River about 45 mi upstream from Florence. Development of the irrigation-canal network in the northern part of the basin was completed in 1933 (Turner and others, 1943).

Flow in the Gila River at Kelvin, which is about 20 mi upstream from the study area, has been monitored since 1912. Annual runoff of the Gila River at Toltec Buttes and at Kelvin for 1897 through 1899 is shown in figure 14. Average runoff in the Gila River at Kelvin was about 574,000 acre-ft/yr before construction of Coolidge Dam (Thomsen and Eychaner, 1991). Average runoff for 1912-84 was about 344,000 acre-ft/yr.

Runoff at Ashurst-Hayden Dam (fig. 14) nearly is the same as at Kelvin because the river flows over shallow bedrock along most of the reach between the two stations and loses little water to infiltration, and a few small ephemeral tributaries contribute to flow below Kelvin. Diversions made before 1930 were large, but few data are available. Davis (1897a) reported that in 1895 the entire flow of the river, except for flow during flood conditions, was diverted near Ashurst-Hayden Dam, and in 1896, 64,444 acre-ft was diverted to the Florence Canal for the irrigation of 6,472 acres. The average diversions at Ashurst-Hayden Dam since 1936 have been about 214,000 acre-ft/yr, and the average runoff past the dam has been about 47,000 acre-ft/yr (fig. 14). The diversions have varied by 200,000 to 400,000 acre-ft/yr. An 11-year running average indicates that diversions decreased from about 200,000 acre-ft/yr in the early 1940 s to about $100,000 \mathrm{acre}-\mathrm{ft} / \mathrm{yr}$ in the early $1950 \mathrm{~s}$ and then increased gradually to about 300,000 acre- $\mathrm{ft} / \mathrm{yr}$ in the late 1970s. Runoff past the dam generally is less than 30,000 acre-ft/yr except for occasional periods when runoff was 100,000 acre-ft/yr or more. The frequency of large flows has been greater since the mid-1960s. The largest annual runoff occurred in 1983 when about 545,000 acre-ft flowed past the dam. 


\section{A. ANNUAL RUNOFF AT KELVIN}

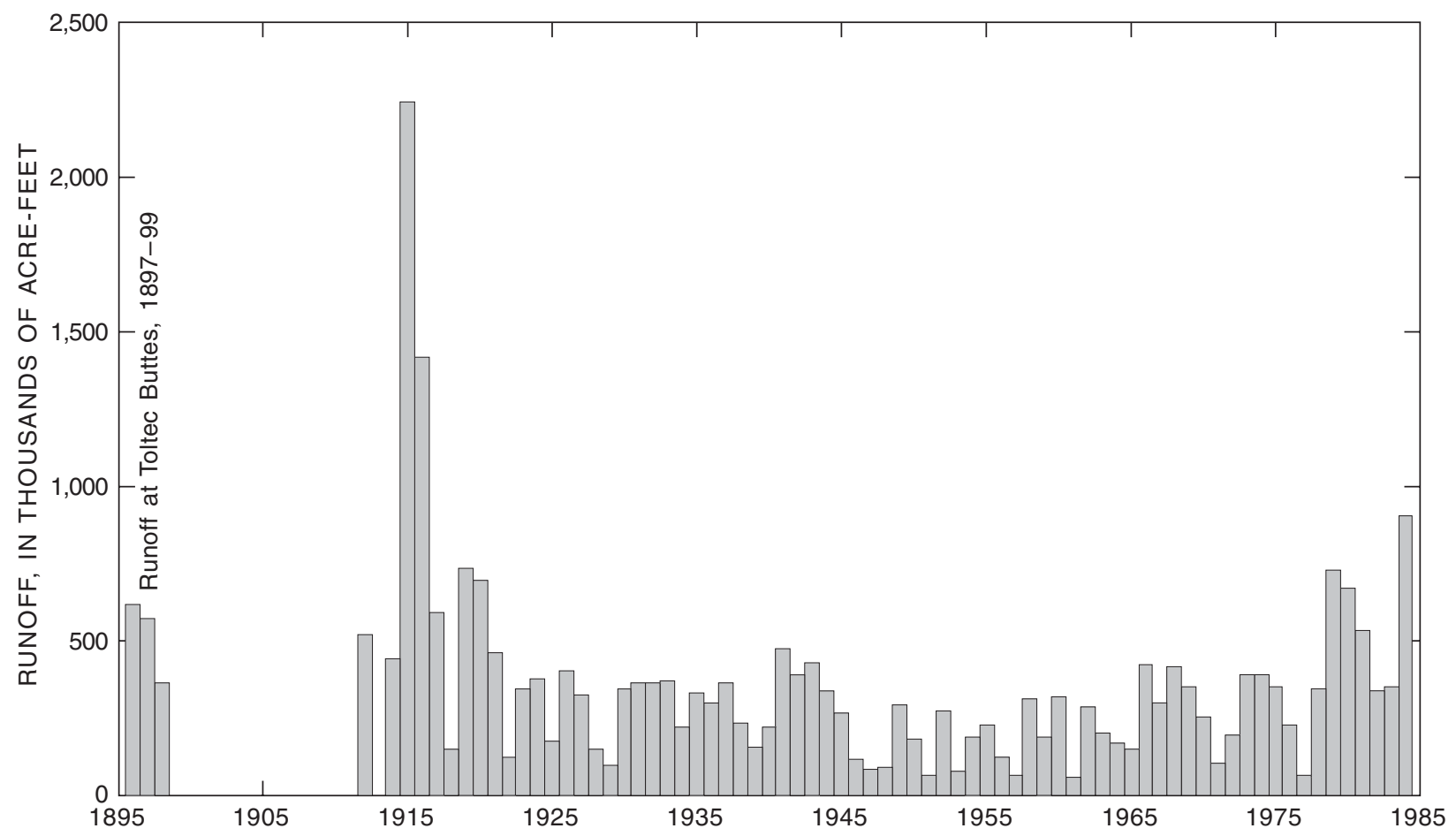

B. ANNUAL FLOW AND DIVERSIONS AT ASHURST-HAYDEN DAM

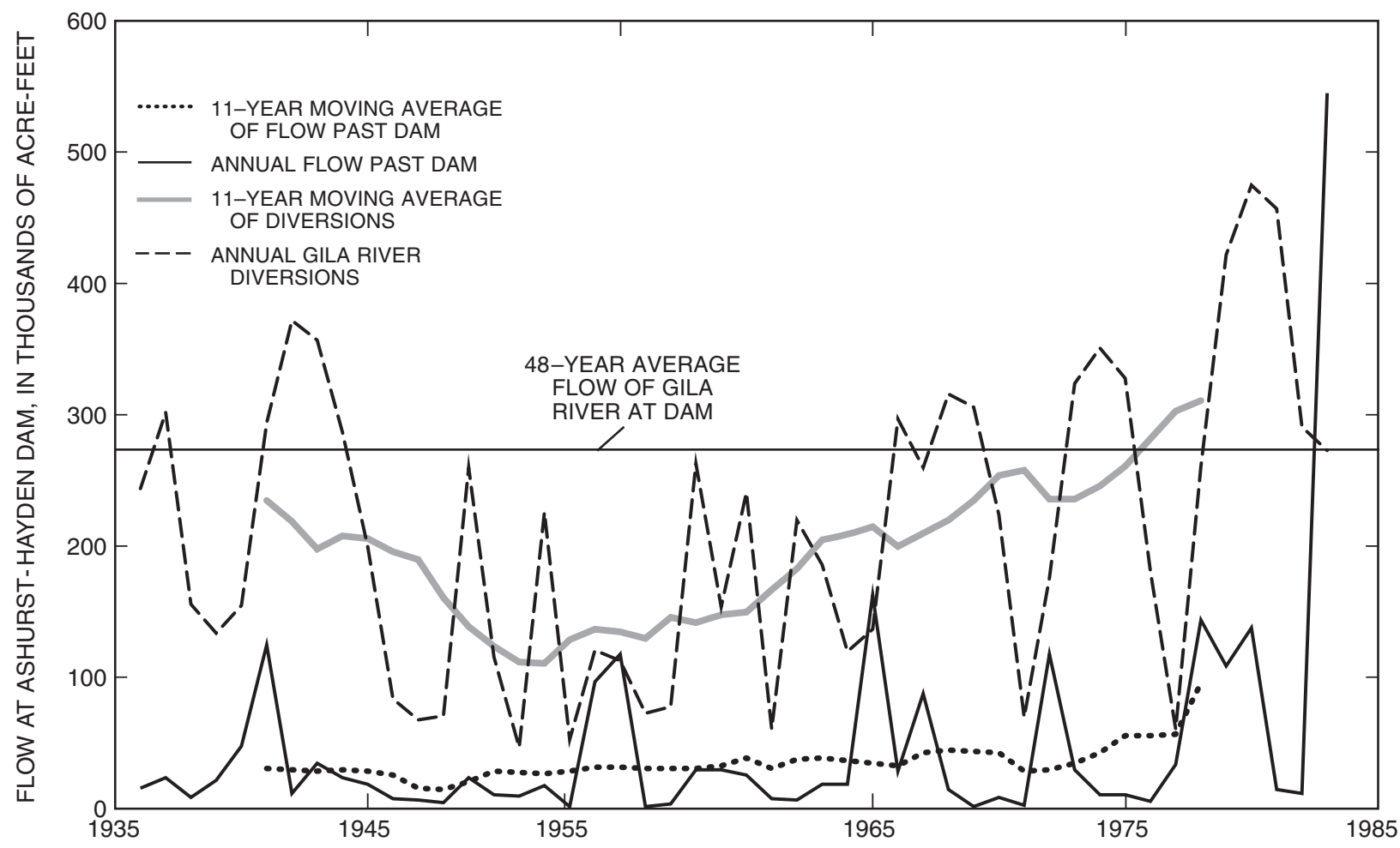

Figure 14. Flow and diversions of the Gila River, Arizona. $A$, Annual runoff at Kelvin. $B$, Annual runoff and diversions at AshurstHayden Dam. 
Flows in the Santa Cruz River were diverted by a canal constructed along the south margin of the basin in 1910 to deliver water to a reservoir in the southwestern part of the basin (Turner and others, 1943). Erosion along the canal caused the capture and diversion of nearly all subsequent flow in the river to the canal. No streamflow data are available from which to estimate discharge of the Santa Cruz River into the basin.

\section{Ground Water}

Ground water in Picacho Basin occurs in aquifers and confining units in the lower, middle, and upper hydrostratigraphic units of basin sediments (fig. 8). Ground water can occur in fractures within the underlying bedrock; however, no wells are known to produce significant quantities of water from these rocks. The principal aquifers are the conglomerate of the lower unit and the sand and gravel interbeds within the alluvial facies of the middle and upper units. The principal confining unit is the bedrock that underlies the basin sediments; the playa facies of the lower, middle, and upper units; and silt and clay interbeds within the alluvial facies of the middle and upper units. Most ground-water flow occurs in aquifers of the middle and upper units, which are more permeable than the deeper aquifers.

The playa facies of the lower, middle, and upper units form one nearly continuous confining unit defined as the middle confining unit. The middle confining unit separates the aquifer system into upper and lower aquifer systems (fig. 8). The upper aquifer system includes aquifers and confining units within the alluvial facies of the middle and upper hydrostratigraphic units. The lower aquifer system includes aquifers and confining units within alluvial facies of the lower and middle hydrostratigraphic units. Local confining units and vertical-head gradients occur within the upper aquifer system. The upper and lower aquifer systems are poorly connected hydraulically where the middle confining unit separates the two aquifer systems. In most areas along the basin margins, the middle confining unit is absent, and the two aquifer systems are well connected and essentially form one aquifer system. In some areas of the basin margin, however, the two aquifer systems are poorly connected because of a large difference in hydraulic properties such as near Casa Grande.

Ground water in the upper aquifer system occurs under unconfined and confined conditions. Unconfined conditions exist where silt and clay interbeds are not significant confining units and no significant differences in vertical-hydraulic head occur between aquifers. Confined conditions exist where silt and clay interbeds restrict the vertical movement of water and significant vertical-head differences exist between aquifers. Confined conditions are common in the eastcentral part of the basin because of the occurrence of thick and laterally continuous silt and clay interbeds. Water-table conditions are predominant on the margins of the basin where thick silt and clay beds are not common. Ground water in the lower aquifer system generally is confined but may be unconfined on the basin margins where the middle confining unit is absent.

Ground water is stored in the pores spaces between grains of sediment and within the crystalline structure of clay minerals. The volume of water stored in the aquifer system is determined by the porosity or percentage of pore spaces in the total volume of the aquifer system. Changes in the ground-water budgetinflows and outflows of the aquifer system-result in changes in water levels and in ground-water storage. Outflow has exceeded inflow over the period of interest to this investigation and has resulted in water-level declines and reduction in ground-water storage. Outflow and losses in ground-water storage primarily occur through drainage of pore spaces in water-table aquifers and reduction of pore volume caused by aquifer-system compaction. Outflow and storage loss also occur through expansion of water volume through reduction in fluid pressure.

Most water lost from aquifer-system storage in the basin is derived from drainage of pore spaces in the upper aquifer system. Significant quantities of water, however, are derived from compaction of pores. In areas where the aquifer system is confined, most water that is lost from storage is derived from compaction of pores. Most water lost from storage in the middle confining unit and lower aquifer system is derived from reduction of pore volume.

Withdrawal of ground water in excess of recharge has resulted in changes in hydraulic gradients, water-level declines, aquifer-system compaction, land subsidence, and the development of earth fissures. Predevelopment and postdevelopment ground-water systems were evaluated through analysis of the hydraulic properties, development of water budgets, and analysis of hydraulic gradients before and during development.

\section{Predevelopment}

Predevelopment ground-water conditions were assumed to be in a state of equilibrium between ground-water inflow and outflow before extensive streamflow diversion and ground-water withdrawal for irrigation. Information on predevelopment conditions is 
scarce, and conditions are not known precisely. The earliest data, as well as data accumulated as develop-ment proceeded, approximates predevelopment conditions as accurately as possible. Data on streamflow, distribution of phreatophytes, water levels in wells, and hydraulic properties of the aquifer were used to estimate streamflow recharge and discharge, evapotranspiration, hydraulic gradients, underflow into the basin, and underflow out of the basin for the predevelopment system.

Collection of hydrologic data in Picacho Basin began after early development of the surface-water supply of the Gila River in the late 1870s. Predevelopment flow of the Gila River is estimated from the earliest measurement of flow in the Gila River in 1887, which provides information on potential quantities of recharge through streambed infiltration. The predevelopment water-table distribution is estimated from early water levels in wells throughout the valley.

The predevelopment water-level altitude is based on data collected from shallow wells within the upper aquifer system from 1897 through 1921 (Thomsen and Baldys, 1985; fig. 15, this report). The earliest waterlevel data were collected about 1900 in the FlorenceCoolidge area near the Gila River and probably are affected by prior redistribution of recharge caused by river diversions at Ashurst-Hayden Dam. Later information is from the Eloy area. Steep gradients existed at the inflow area between Picacho Peak and the Silverbell Mountains. Inflow from adjacent aquifers to the east also probably occurred in areas north of the Picacho Mountains and between Picacho Peak and the Picacho Mountains where no water levels are available. The main areas of ground-water outflow were south of the Casa Grande Mountains, at Casa Grande, and beneath the Gila River between the Sacaton and Santan Mountains. Hydraulic gradients ranged from about $10 \mathrm{ft} / \mathrm{mi}$ across the southern part of the basin to about $8 \mathrm{ft} / \mathrm{mi}$ along the Gila River.

The general distribution of hydraulic head shown on the predevelopment water-level map (fig. 15) probably is similar to conditions that existed before any development. Water levels near the Gila River may be underestimated because of water-level declines caused by diversions and diminished recharge along the river. Water levels near the Florence-Casa Grande Canal and Picacho Reservoir may be higher than those that existed during predevelopment because infiltration of water along the canals had been occurring since 1887 . Predevelopment water levels in the southern part of the basin represent water-level altitudes in shallow wells that were drilled before 1922 .

The upper aquifer system generally existed under water-table conditions during predevelopment; however, confined conditions in the lower and upper aquifer systems have been documented by Lee (1904) and Smith (1940). In 1901, a deep well drilled at Casa Grande yielded water under confined conditions in red sandstone of the lower aquifer system at depths of more than $600 \mathrm{ft}$ (Lee, 1904). Water levels in the deep well were $7 \mathrm{ft}$ below water levels in a shallow well that tapped the upper aquifer system at the depths of less than $190 \mathrm{ft}$. Smith (1940) found confined conditions within sand and gravel interbeds at depths of more than $500 \mathrm{ft}$ during extensive development of the Eloy area in the middle to late 1930s. Depths of about $500 \mathrm{ft}$ generally are near the top of the middle confining unit (fig. 9, geologic section B-B'). These wells probably tapped local confined aquifers interbedded within playa facies of the upper hydrostratigraphic unit. Water levels in the wells were more than $50 \mathrm{ft}$ above water levels in shallower wells in the area at the time of drilling and 30 to $50 \mathrm{ft}$ above the predevelopment water levels indicated on figure 15. Information from these early deep wells indicates that significant vertical-hydraulic gradients existed during predevelopment.

\section{Postdevelopment}

Development of the surface-water and groundwater supplies caused the following changes to the aquifer system: (1) removal of water from storage, (2) changes in directions and gradients of ground-water flow, (3) increased rates and wider distribution of recharge and discharge, and (4) reduced surface flow in the Gila River. During postdevelopment, the groundwater system has been changing continually because withdrawals for irrigation have exceeded recharge. The most significant changes are water-level declines and land-surface subsidence that have been caused by the removal of water from aquifer-system storage. Declin-ing water levels also have resulted in changes in the general directions and gradients of ground-water flow and the removal of water from aquifer-system storage. Sources of water from storage include drainage of water from pore spaces in sediments, compaction of pores, and expansion of the water. Compaction has resulted in land subsidence, and the volume of land subsidence is equivalent to the reduction in pore volume and volume of water removed from compressible sediments. Distribution of irrigation water has introduced additional recharge sources including deep percolation of excess applied irrigation water throughout the valley and infiltration along the distribution system. Diversion of Gila River water for irrigation has reduced flows and recharge through infiltration along the streambed. 


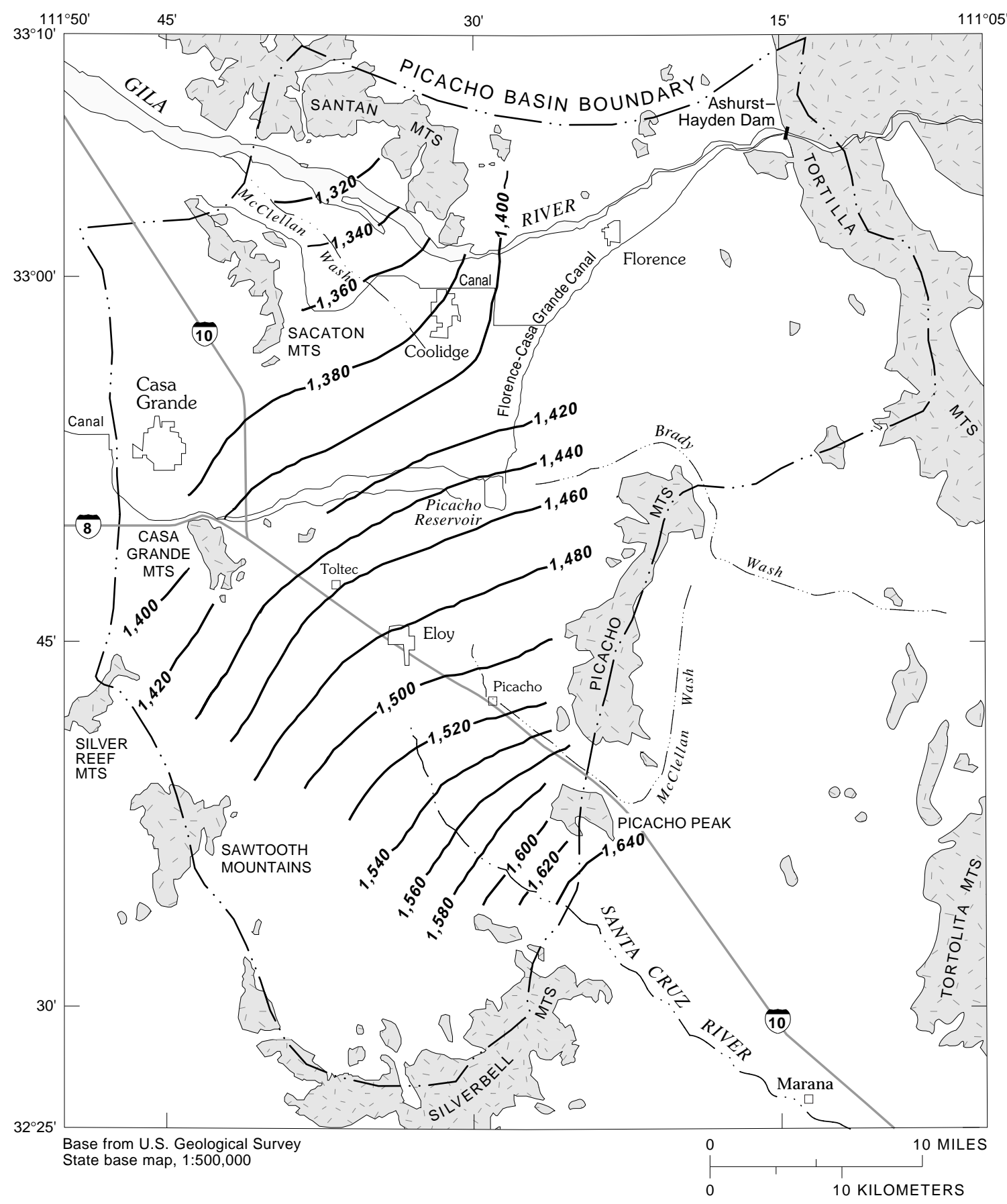

\section{EXPLANATION}

BASIN SEDIMENTS AND SURFICIAL ALLUVIAL DEPOSITS

CRYSTALLINE ROCK

—1,500 — ALTITUDE OF WATER LEVELContour interval 20 feet

Figure 15. Predevelopment water-level altitudes in the upper unit of Picacho Basin, Arizona. 


\section{Development of Ground-Water Supplies. -}

The earliest development of the ground-water supply began in the late 1890s near the Gila River with the drilling of wells for irrigation during periods of insufficient river flow (Davis, 1897a). Ditches were constructed in the early 1900 s to exploit shallow ground water north of the Gila River near the Santan Mountains where water levels originally were $4 \mathrm{ft}$ above the riverbed (Lee, 1904). The first use of ground water outside the Gila River area was at Casa Grande where the railroad company had obtained water from a dug well before 1901. In 1901, two wells were drilled to depths of 625 and $635 \mathrm{ft}$ and produced water from a 10-foot zone of coarse sand in red sandstone (Lee, 1904). These early developments did not withdraw significant quantities of water and did not alter significantly the predevelopment ground-water flow system.

Documentation of well construction and exploitation of the ground-water supply for irrigation through the early 1950s is supplied by Smith (1940), Turner and others (1943), and Halpenny and others (1952). Several irrigation wells were drilled near Toltec from about 1914 to 1918, but many soon were abandoned. The first well in the Eloy area was drilled in 1916. More than a dozen wells were in operation in the Eloy area by 1930 for the irrigation of about 4,000 acres. About 1914, well drilling for irrigation in the Florence-Casa Grande area began and included private wells and wells drilled for the San Carlos Irrigation Project. In the mid-1930s, extensive development of the ground-water supply for irrigation began with development in the Eloy area. During 1936 and 1937, 40 to 50 new wells were drilled to depths of 300 to $600 \mathrm{ft}$ in the Eloy area, and an additional 13,000 or 14,000 acres were cultivated. In 1939, 81 wells were discharging water into the San Carlos Irrigation Project canals for distribution throughout the system.

The greatest expansion of well construction occurred during the mid-1930s to early 1950s at which time most of the irrigable land in the basin was being farmed (fig. 16). Well construction decreased gradually after the early 1950s. Much of the well construction after the early 1950s (fig. 16) is actually a deepening or replacement of old wells. Reductions in the irrigated land occurred with the abandonment of irrigated areas beginning in the 1960s.

During the early years of development, nearly all wells were shallow and yielded water from the upper aquifer system. Development of water supplies in the lower aquifer system began during the mid-1940s in the Casa Grande area and the area south of the Casa Grande Mountains. Development of the lower aquifer system in the northern part of the basin began after the mid-1950s. The lower aquifer system was not extensively developed in other regions of the basin because of great depth or lack of thickness.

From 1900 to 1983, cumulative length of interval in wells that are open to each aquifer system increased (fig. 17). Cumulative values do not account for abandonment of wells. The data show that, for later years, about one-quarter of the open interval is in the lower aquifer system. The upper aquifer system is much more permeable than the lower aquifer system and, therefore, yields more than three-quarters of the total volume of water withdrawn.

Water-Level Declines.-Ground-water withdrawals in excess of recharge have resulted in declining water levels. Water-level declines through 1983 range from less than $100 \mathrm{ft}$ in the northern part of the basin to more than $350 \mathrm{ft}$ in the southern part.

The areal and temporal trend of decline varies between aquifer systems. Water levels in the upper aquifer system in the northern part of the basin have declined less than water levels in the southern part because of less withdrawal and greater amounts of recharge. Water levels in the lower aquifer system have declined significantly more than water levels in the upper aquifer system throughout the basin. Vertical-hydraulic gradients within and between aquifer systems became more significant as development progressed.

Data from 12 selected wells (fig. 18) are used to describe water-level declines and aquifer-system response to withdrawal stress. Water levels in eight of the wells represent water levels in the upper aquifer system (fig. 19). Collection of water-level data began in the early 1940s. Data are not sufficient to present longterm hydrographs of water levels in the lower aquifer system. Widespread differences in hydraulic head between the upper and lower aquifer systems were not apparent until after 1965.

Initial rates of water-level decline are linear for several years followed by a period of lower rates of decline for all wells except well (D-09-08)22ddd (fig. 19). Rates of decline for well (D-09-08)22ddd have been near constant. Initial rates of water-level decline are less than about $7 \mathrm{ft} / \mathrm{yr}$ in wells (D-05-09)29ada, (D-06-09)04ddd, (D-06-06)12bdb, and (D-08-06)35ddd2, which are on the basin margins. Initial rates are more than $8 \mathrm{ft} / \mathrm{yr}$ in wells (D-07-08)05dcc, (D-08-08)10cdd, (D-08-08)18cdd1, and (D-09-08)22ddd, which are in the basin center. All hydrographs except for (D-09-08)22ddd indicate that decreased rates of water-level decline occurred sometime after the middle 1950s. 


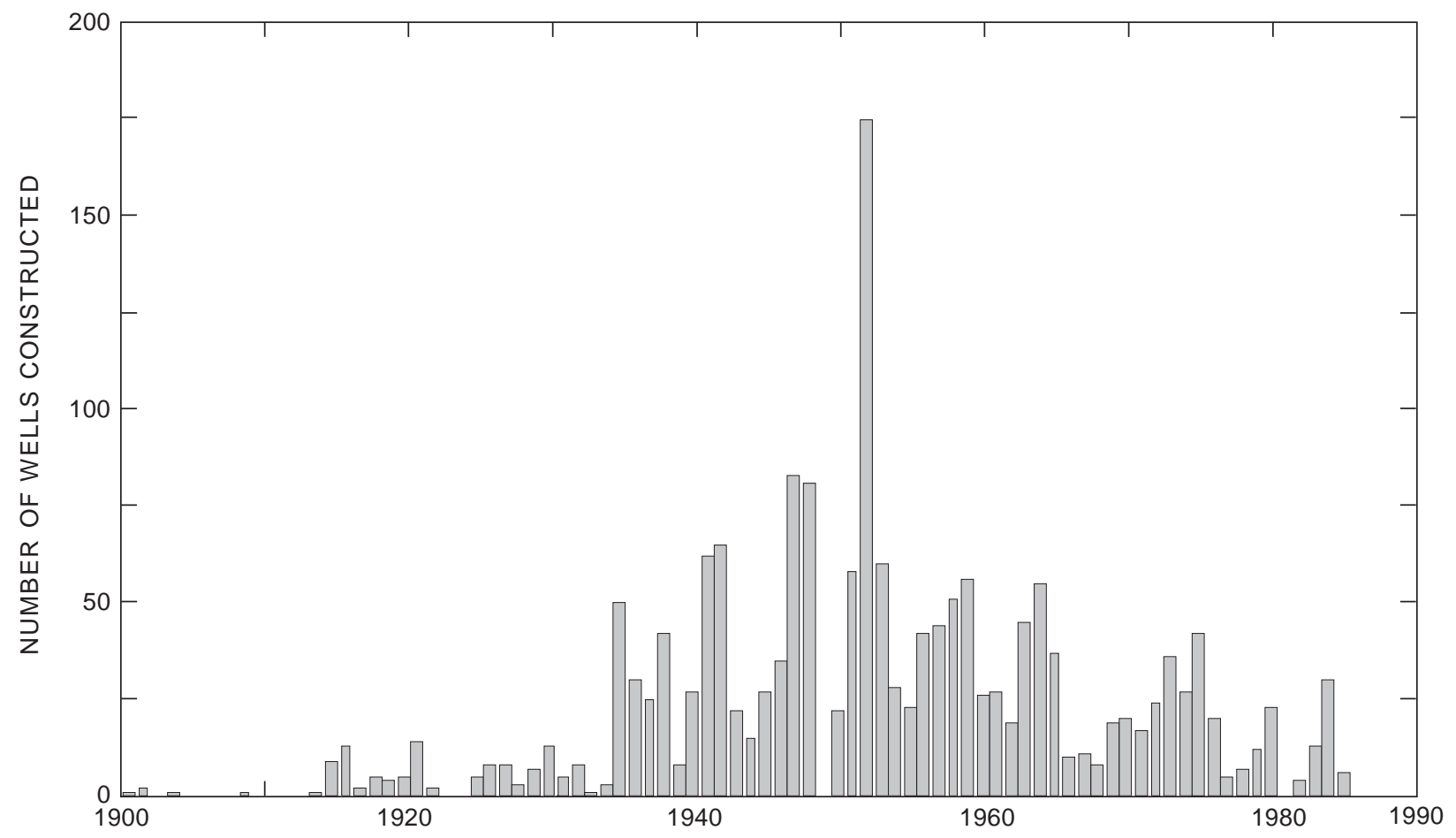

Figure 16. Annual well construction in Picacho Basin, Arizona, 1900-84.

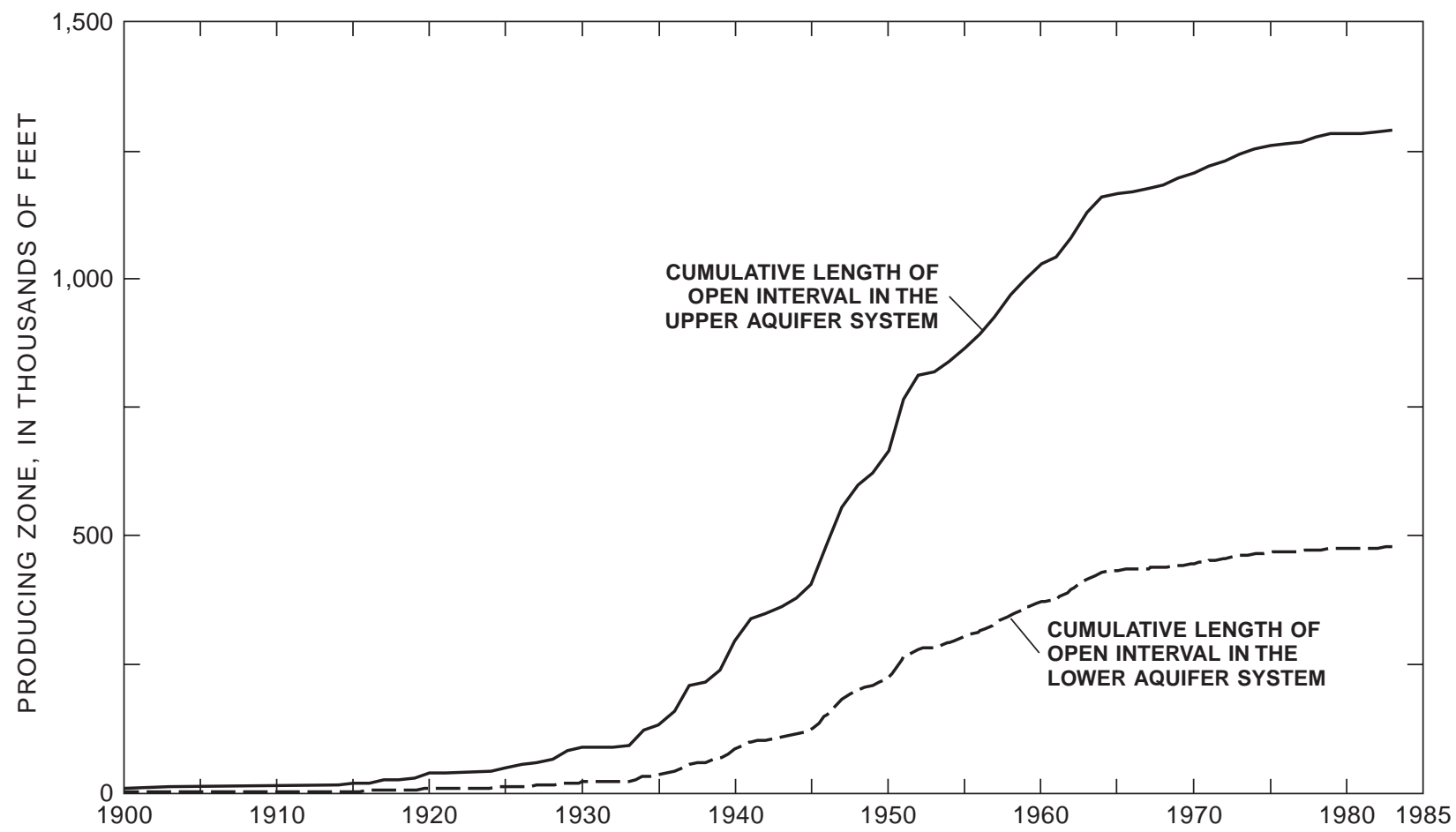

Figure 17. Cumulative length of open interval in wells in the upper and lower aquifer systems in Picacho Basin, Arizona, 1900-83. 


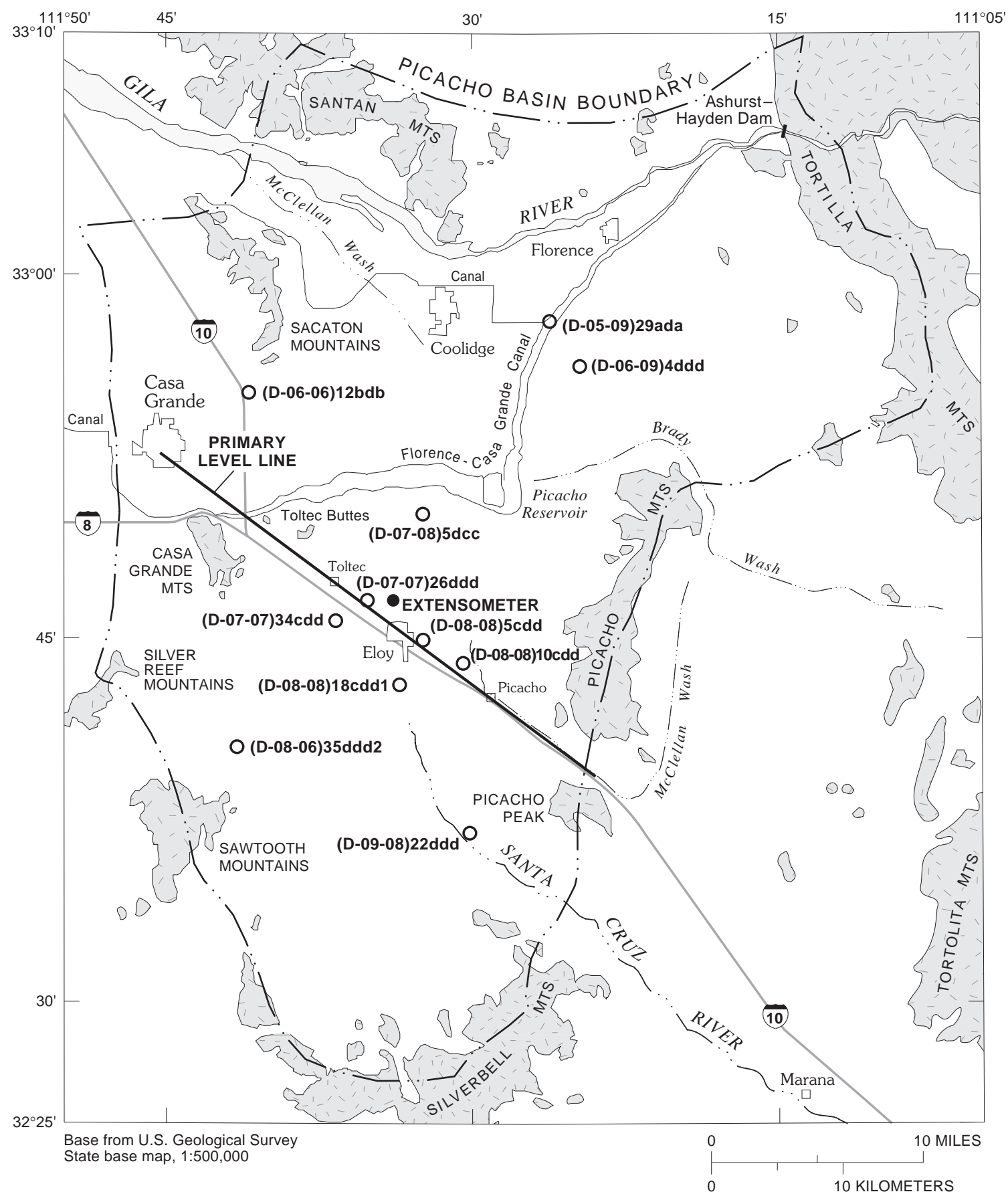

EXPLANATION

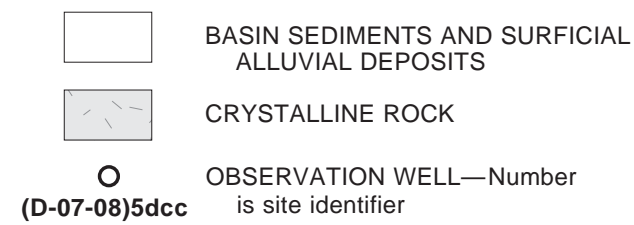

Figure 18. Selected observation wells and primary level line in Picacho Basin, Arizona. 

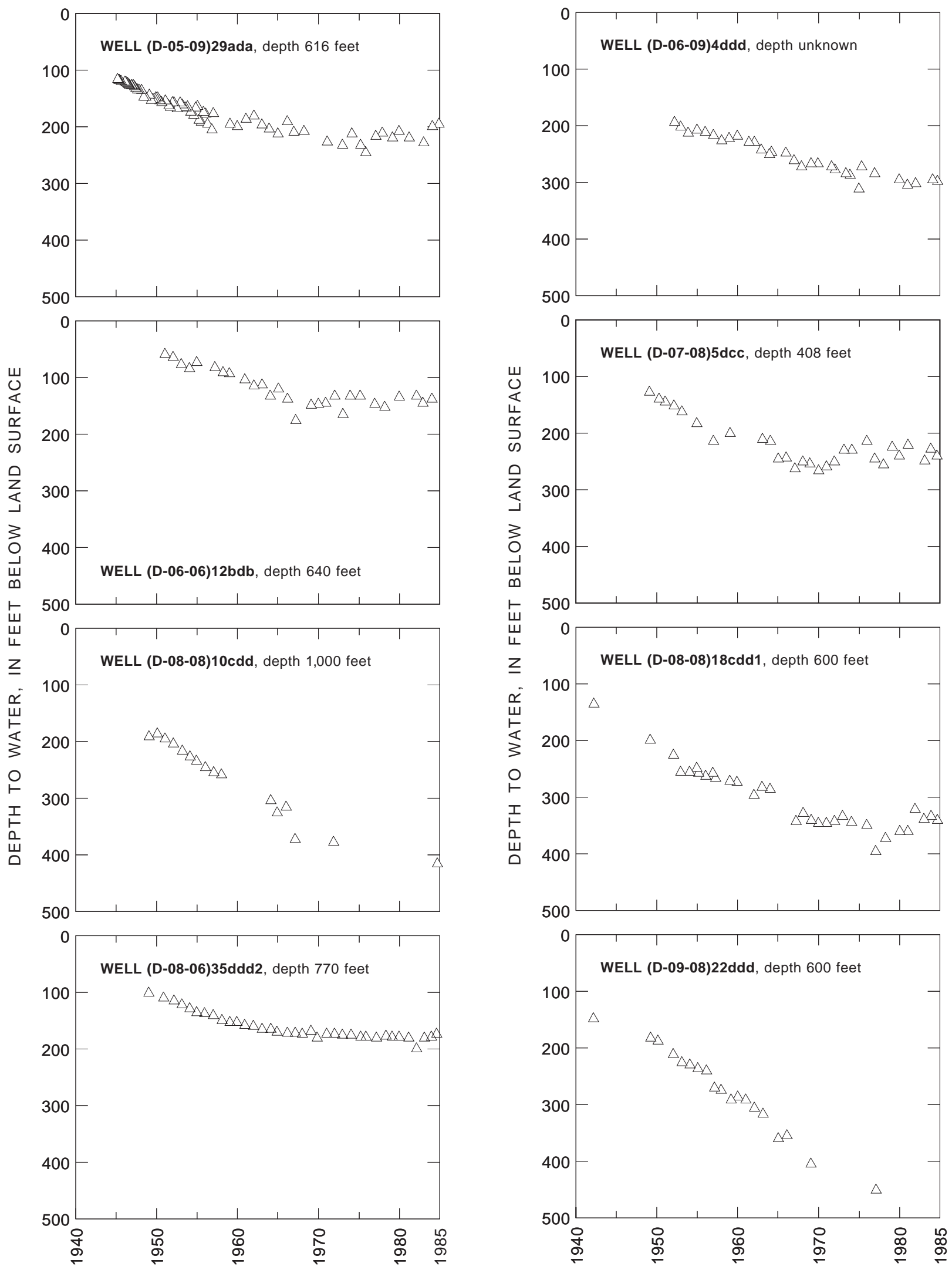

Figure 19. Water levels in selected observation wells in Picacho Basin, Arizona. 
Differences in the rates of water-level decline can be caused by temporal variations in local withdrawal rates, storage properties, recharge, and proximity to hydrologic boundaries. Rates of withdrawal can differ because of local changes in irrigated crops, amounts of irrigated land, or quantity of surface water available for irrigation. Greater rates of water-level decline occur in the basin center where the aquifer contains the greatest percentage of silt and clay and is expected to have smaller storage coefficients. Hydrologic boundaries, such as impermeable rocks, and sources of recharge or discharge also affect rates of water-level decline.

Nearby impermeable rocks can cause increased decline rates; however, none of the wells appears to be affected by proximity to an impermeable boundary with the possible exception of well (D-09-08)22ddd. Nearby recharge through infiltration along streams and canals could cause decreased decline rates. The greater frequency of larger flows along the Gila and Santa Cruz Rivers and increased precipitation after the middle 1950s may have contributed to the decreased rates of water-level decline especially near the major streams.

Water levels in the basin center typically declined about $50 \mathrm{ft}$ over 1- to 2-year periods during the mid-1960s followed by decreased rates of decline. The water levels in wells (D-08-08)10cdd and (D-08-08)18cdd1 for 1967 are typical of this occurrence (fig. 19). The rapid water-level declines during the mid-1960s could have been caused by dewatering of local shallow aquifers that had higher hydraulic head than the deeper aquifers.

The spatial distribution of water-level changes is illustrated by maps showing water-level decline since predevelopment to $1950,1965,1977$, and 1985 (figs. 20-24). Declines at each well location were calculated by subtracting the water-level altitude for each year from the projected predevelopment waterlevel altitude (fig. 15) at each well. Data used to construct the 1950, 1965, and 1977 maps primarily are from the upper aquifer system but may include data from the lower aquifer system (figs. 23 and 24).

Water levels in 1950 had declined more than $50 \mathrm{ft}$ throughout most of the southern part of the basin and a maximum of about $100 \mathrm{ft}$ near Eloy (fig. 20). Declines generally were less than $50 \mathrm{ft}$ in the northern part of the basin. Some decline had occurred at inflow and outflow areas indicating changes in hydraulic gradients and changes in rates of underflow.
By 1965, water levels had declined more than $100 \mathrm{ft}$ throughout most of the basin except along the Gila River and south of the Casa Grande Mountains (fig. 21). The greatest declines of more than $200 \mathrm{ft}$ occurred in the southeastern part of the basin.

The same general trend of water-level declines persisted to 1977 (fig. 22). More than $150 \mathrm{ft}$ of decline had occurred throughout most of the basin with the exception of the extreme northern part. More than $300 \mathrm{ft}$ of decline had occurred in the southeastern part. Declines of less than $100 \mathrm{ft}$ occurred between Coolidge and Picacho Reservoir near Casa Grande and between the Santan and Sacaton Mountains along the Gila River. Water levels declined about $250 \mathrm{ft}$ in the lower aquifer system south of the Casa Grande Mountains, but data were insufficient to map declines in the lower aquifer system.

The general distribution of water-level declines in the upper aquifer system had not changed by 1985 (fig. 23). The magnitude of decline in the southeastern part of the basin increased to more than $350 \mathrm{ft}$. Declines of less than $100 \mathrm{ft}$ occurred between Coolidge and Picacho Reservoir and along the Gila River. Waterlevel recovery near the Gila River probably was caused by the flood of 1983-84. Declines in the lower aquifer system are estimated from a few wells on the west margin of the basin (fig. 24). Water levels had declined more than $200 \mathrm{ft}$ near Casa Grande and more than $400 \mathrm{ft}$ south of the Casa Grande Mountains (fig. 24).

The postdevelopment ground-water flow system has become more complex because of changes in horizontal-hydraulic gradients and changes in verticalhydraulic gradients within the upper aquifer system and between the upper and lower aquifer systems. Discharge occurs from wells in both the upper and lower aquifer systems throughout much of the basin. Recharge occurs along the major streams and the irrigation-distribution system and at Picacho Reservoir. Water-level declines resulted in reversal of hydraulic gradients at predevelopment outflow areas. By 1965, ground-water inflow occurred between all mountain ranges where the aquifer system is connected hydraulically to aquifers in adjacent basins.

Flow generally occurs from the basin margins to a trough that extends in a north-northwestward direction from southeast of Eloy to the Sacaton Mountains (fig. 25). Water-level altitudes ranged from 1,300 to $1,350 \mathrm{ft}$ above sea level on the basin margins and from about 1,250 ft between Eloy and the Sacaton Mountains to less than $1,150 \mathrm{ft}$ near Picacho. 


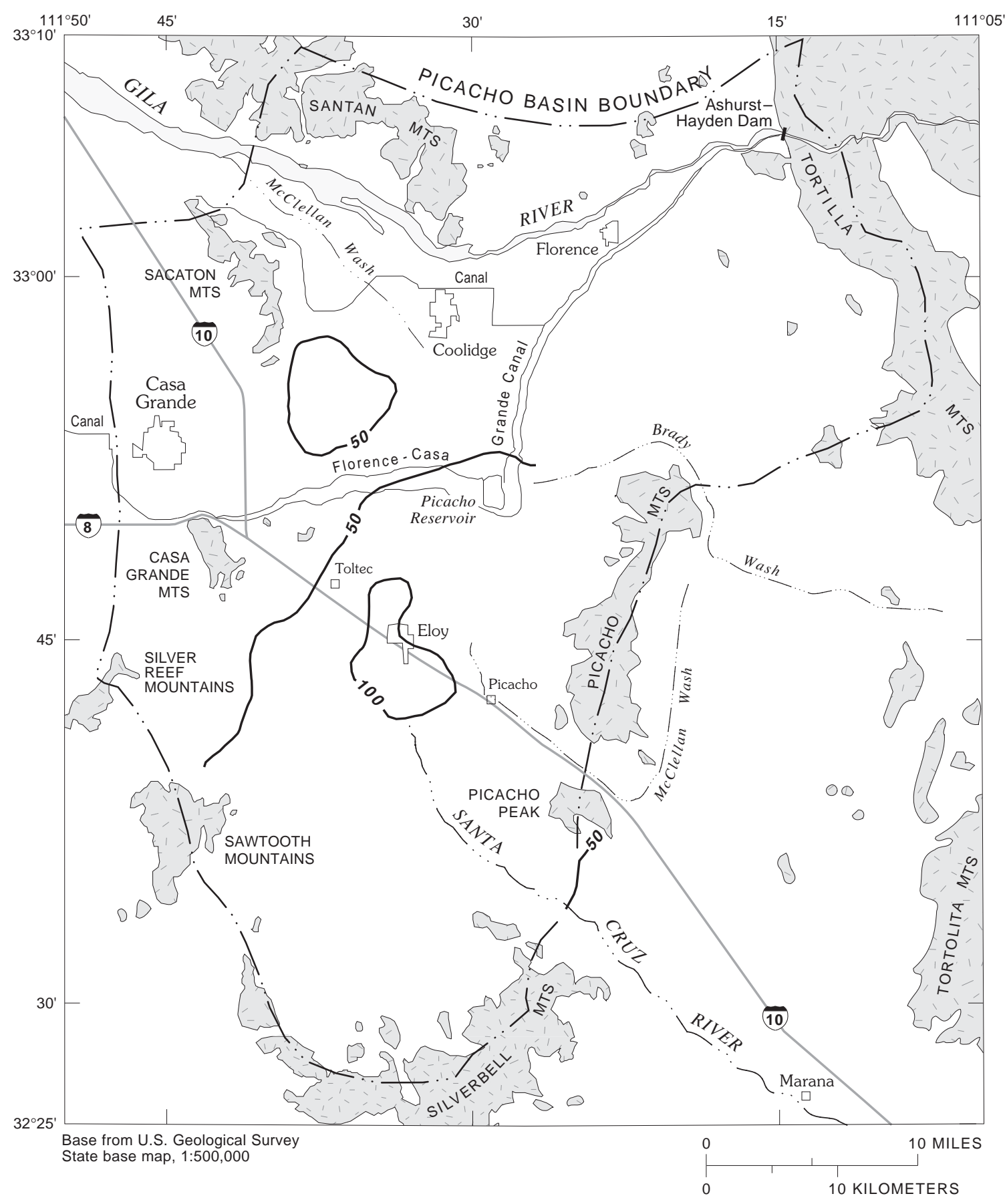

EXPLANATION

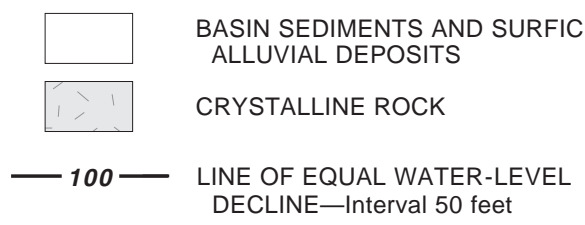

Figure 20. Water-level decline from predevelopment to 1950 in Picacho Basin, Arizona. 


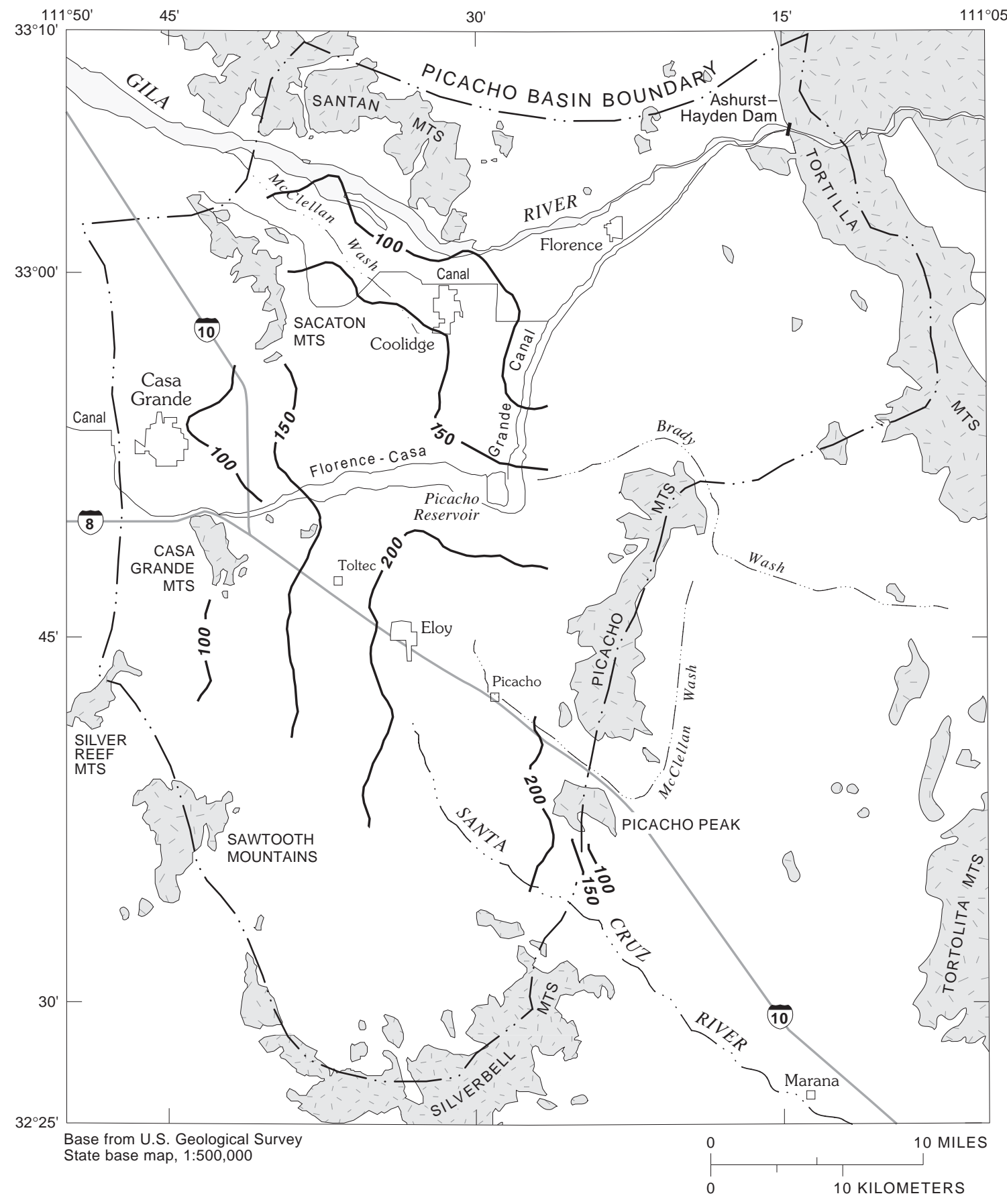

EXPLANATION

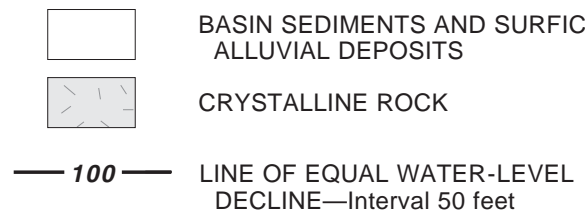

Figure 21. Water-level decline from predevelopment to 1965 in Picacho Basin, Arizona. 


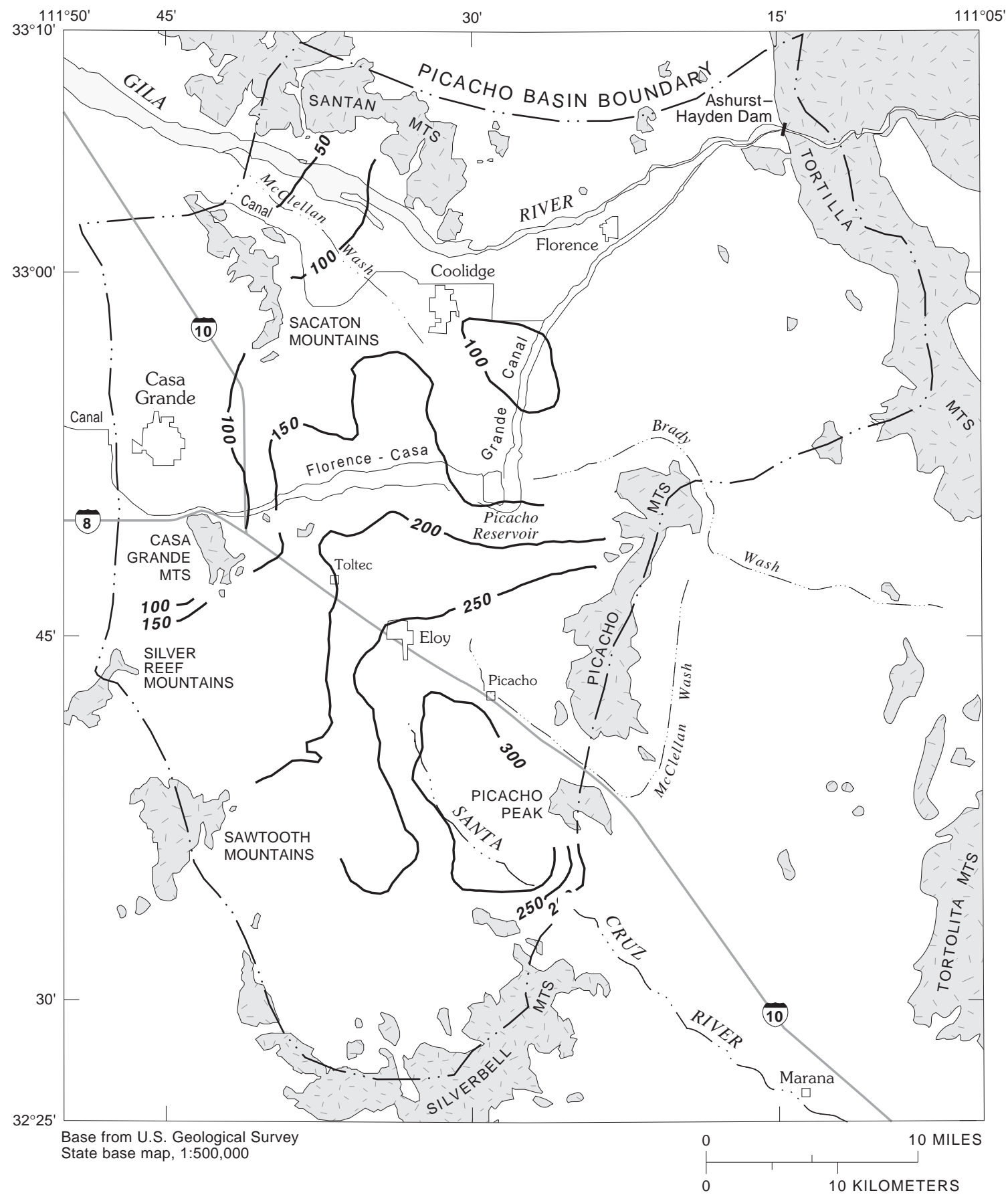

EXPLANATION

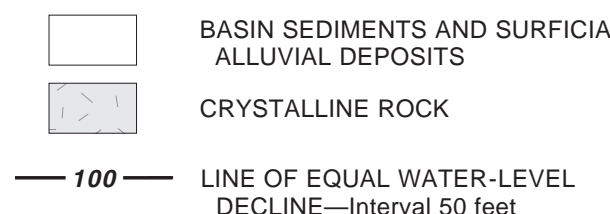

Figure 22. Water-level decline from predevelopment to 1977 in Picacho Basin, Arizona. 


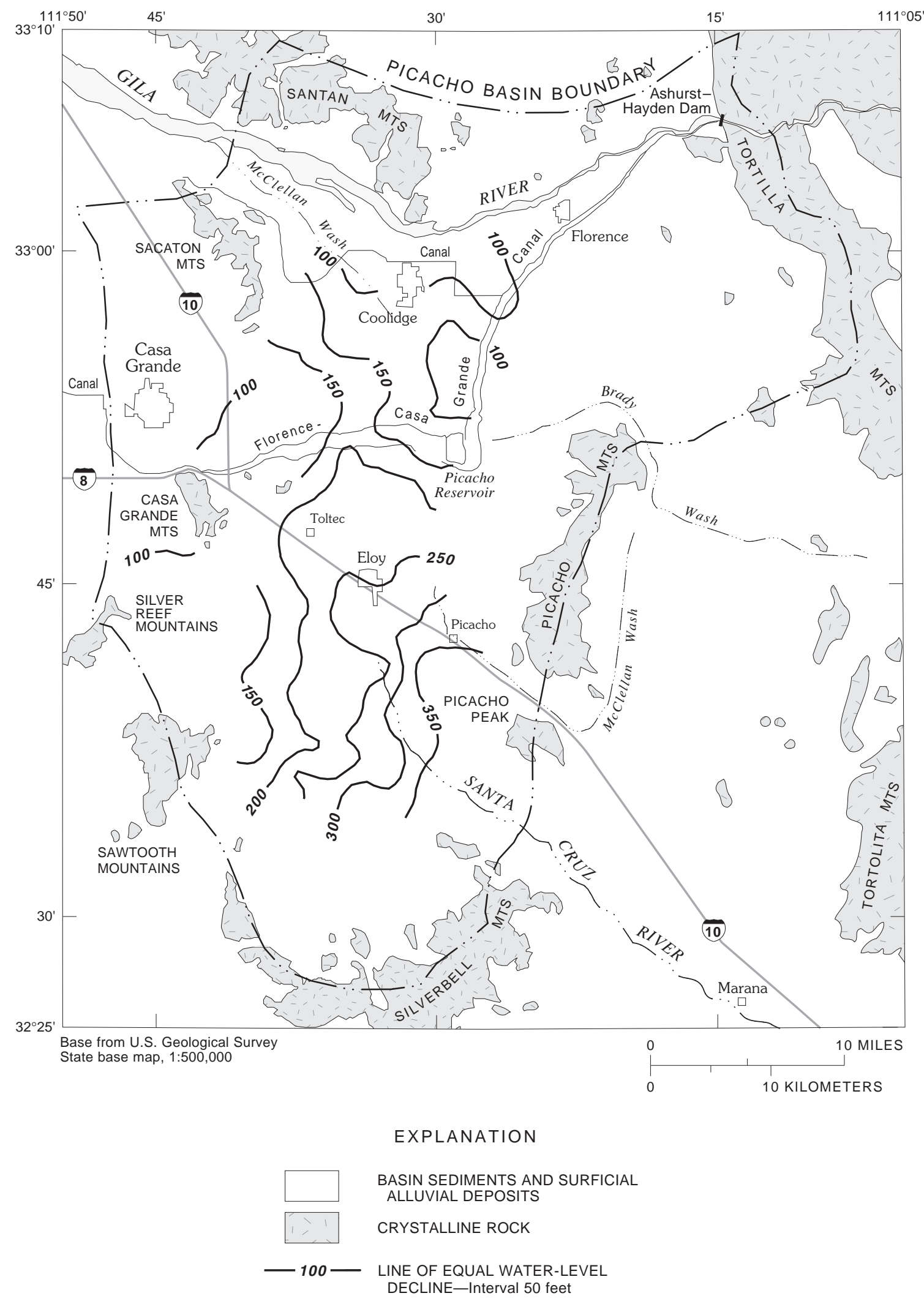

Figure 23. Water-level decline from predevelopment to 1985 in the upper aquifer system of Picacho Basin, Arizona. 

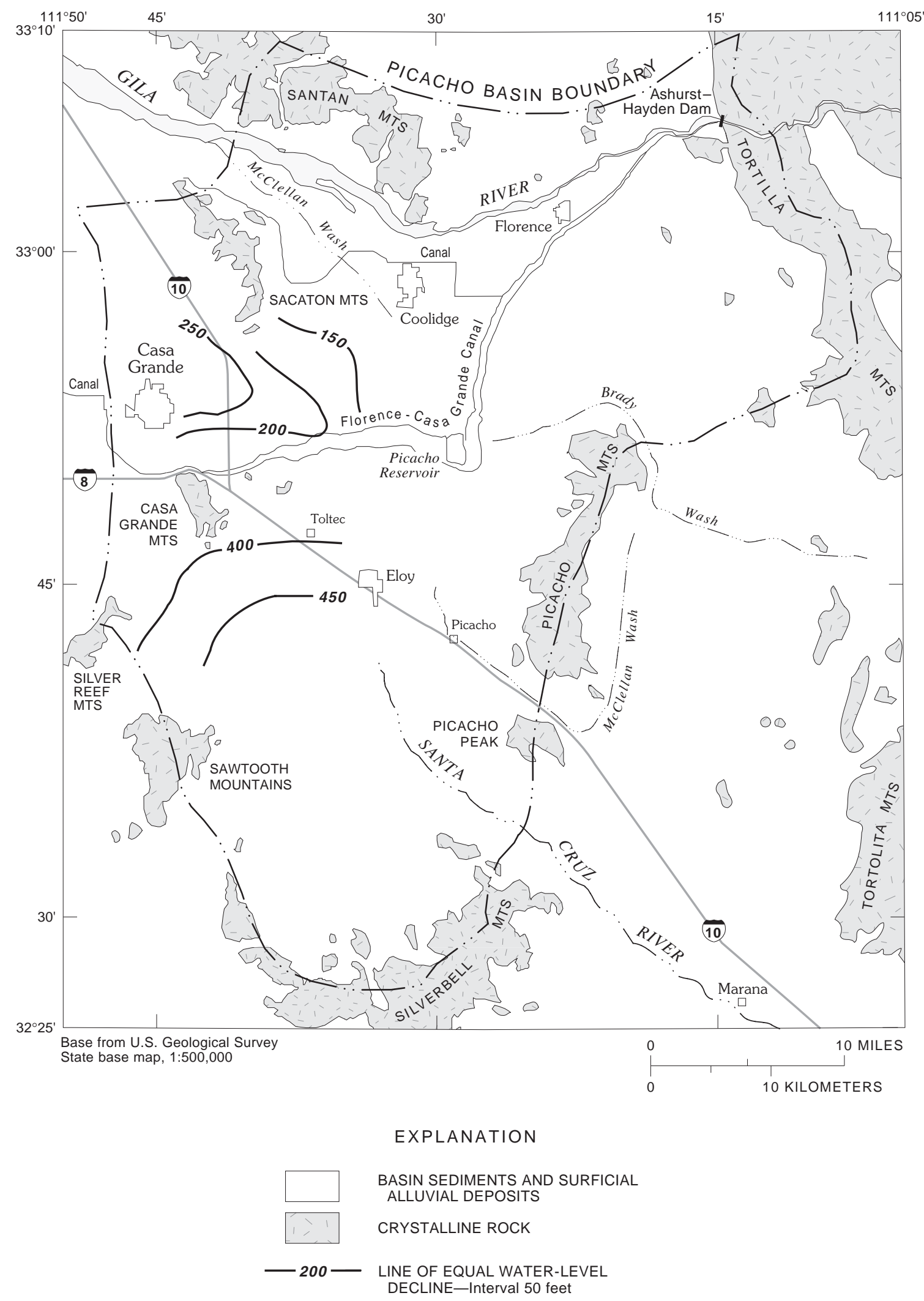

Figure 24. Water-level decline from predevelopment to 1985 in the lower aquifer system in the western part of Picacho Basin, Arizona. 


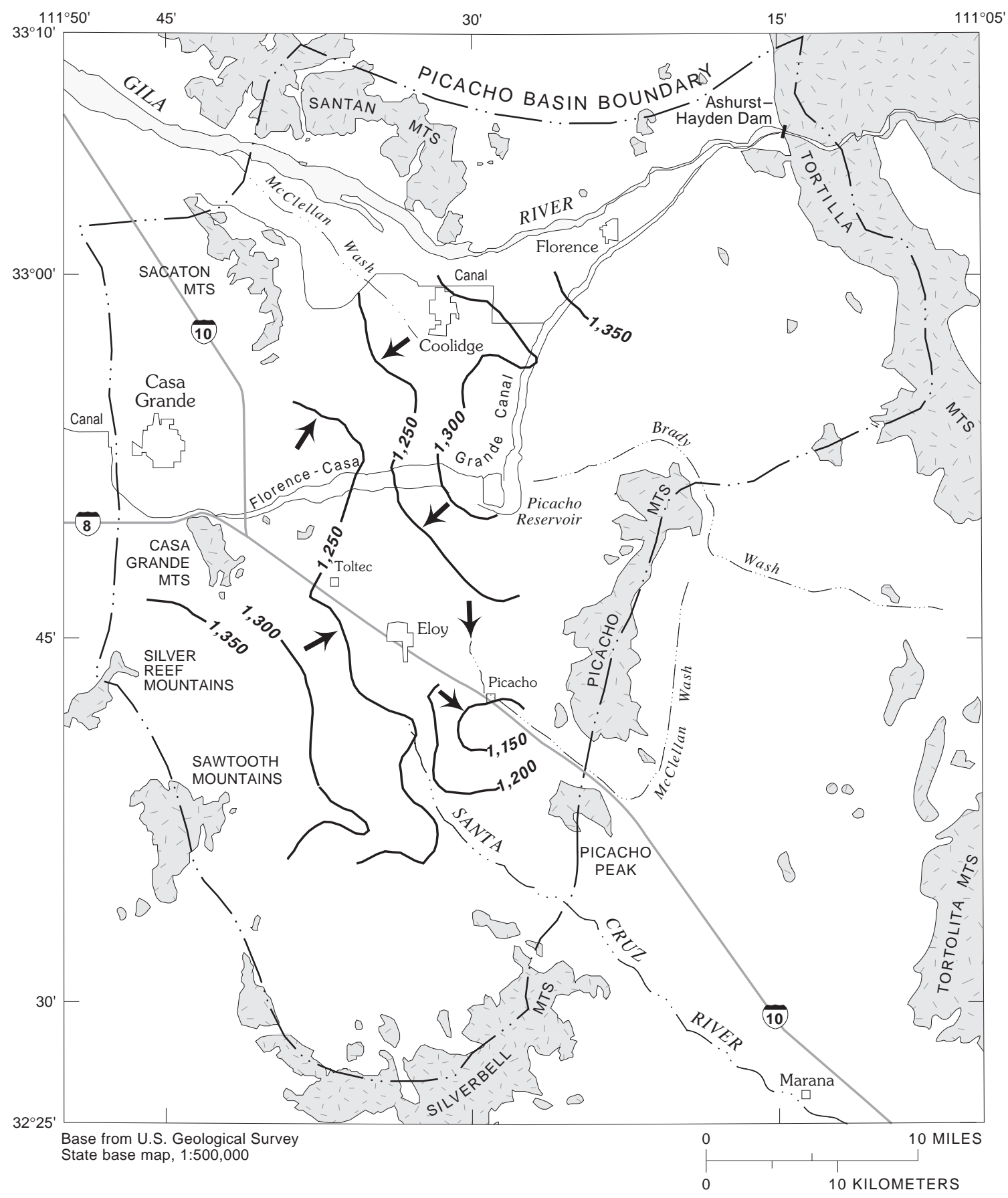

EXPLANATION

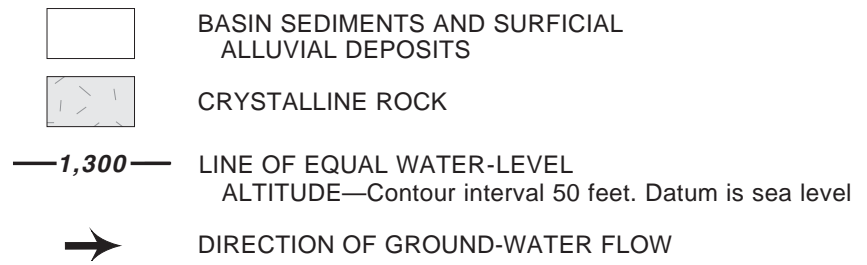

Figure 25. Water-level altitude and direction of ground-water flow for 1965 in the upper aquifer system of Picacho Basin, Arizona. 
Water levels that are representative of the lower aquifer system are available only along the west margin of the basin (fig. 26). Flow directions are different significantly from those in the upper unit; flow in the lower aquifer system generally is toward the west edge of the basin. Water-level altitudes generally are the same as in the upper aquifer system northeast of Casa Grande and 100 to $200 \mathrm{ft}$ lower on the west margin of the basin. Vertical-hydraulic gradients between the lower and upper aquifer systems are as great as 100 times the horizontal gradients in some areas.

Significant vertical differences in water-level altitude have developed within the upper aquifer system in the Eloy area and induced downward flow. The water-level altitudes for 1985 in wells in the area of lowest water-level altitudes near Eloy are plotted against the altitude of the bottom of the wells (fig. 27). The wells are open only to the upper aquifer system. Several water-level altitudes are higher than shown by the generalized contours on figure 25 . The deeper wells - those in which the bottom of the well is below $300 \mathrm{ft}$ in altitude-have water levels below 1,200 ft in altitude; whereas, the shallow wells have a wide scatter of water levels ranging from 1,150 to more $1,350 \mathrm{ft}$ in altitude. The presence of shallow water levels in some shallow wells indicates that zones of higher hydraulic head must exist within the shallow part of the upper aquifer system. Similar conditions may exist to some degree in other parts of the basin; however, vertical differences in water-level altitude in the upper aquifer system are most obvious in the Eloy area. The vertical differences in hydraulic head could be caused by the high degree of development and several thick local confining beds in the Eloy area (fig. 9, geologic sections $\mathrm{B}-\mathrm{B}^{\prime}$ and $\left.\mathrm{D}-\mathrm{D}^{\prime}\right)$.

Land Subsidence and Aquifer Compaction._-Land subsidence and aquifer compaction have been documented throughout much of Picacho Basin (Laney and others, 1978; Schumann, 1986). Subsidence was first detected in 1936 on releveling of a 1905 first-order level line from Casa Grande to near Picacho Peak; at that time, less than $0.5 \mathrm{ft}$ of subsidence was detected west of Eloy (Robinson and Peterson, 1962). This level line, designated a primary level line, has been releveled several times (fig. 18). Laney and others (1978) indicated that more than $2 \mathrm{ft}$ of subsidence had occurred between 1952 and 1977 in all areas except near the Gila River and at the extreme margins of the basin. The widespread occurrence of earth fissures (fig. 4) mainly along the basin periphery has been documented by Laney and others (1978). Subsidence increased to more than $12 \mathrm{ft}$ in 1984 along the primary level line (fig. 28). By 1985, maximum subsidence of more than $15 \mathrm{ft}$ had been measured south of Eloy (Schumann, 1986).

Correlation between land subsidence and declining water levels in Picacho Basin has been well established by several investigators (Robinson and Peterson, 1962; Schumann and Poland, 1970). Ground-water withdrawals and declining water levels cause a reduction in hydrostatic pressure and an increase in load, or effective stress, applied to the aquifer.

The increased effective stress causes a reduction in the volume of pore spaces within compressible parts of the aquifer, resulting in aquifer compaction, which is observed as subsidence of the land surface.

Deformation of the aquifer occurs as elastic and inelastic compaction. Elastic compaction is recoverable and occurs at levels of effective stress that are less than the maximum effective stress previously applied to the aquifer. The previous maximum effective stress to which the aquifer system has been subjected is termed preconsolidation stress (Poland, 1972). Inelastic compaction occurs at levels of effective stress that are greater than the previous maximum effective stress.

Extensive earth fissuring has occurred concurrently with land subsidence. The first recognized earth fissure occurred in 1927 about $3 \mathrm{mi}$ southeast of Picacho (Leonard, 1929). Many earth fissures have since been mapped by several investigators (fig. 4). Most of the fissures occur near the basin margins and generally are considered to be the result of differential compaction caused by changes in thickness of compressible materials across local structural highs in the bedrock surface (Jachens and Holzer, 1979). A few of the fissures occur far from the basin margins where local variations in thickness of compressible material are not thought to be significant. These fissures may be the result of local variations in aquifer compressibility or stress.

Other possible mechanisms of subsidence can occur but probably contribute little to the total amount of measured subsidence. These mechanisms include natural compaction of sediments, dissolution of gypsum and halite, chemical phase change of gypsum to anhydrite, subsurface flow of halite, and tectonic basin subsidence. 


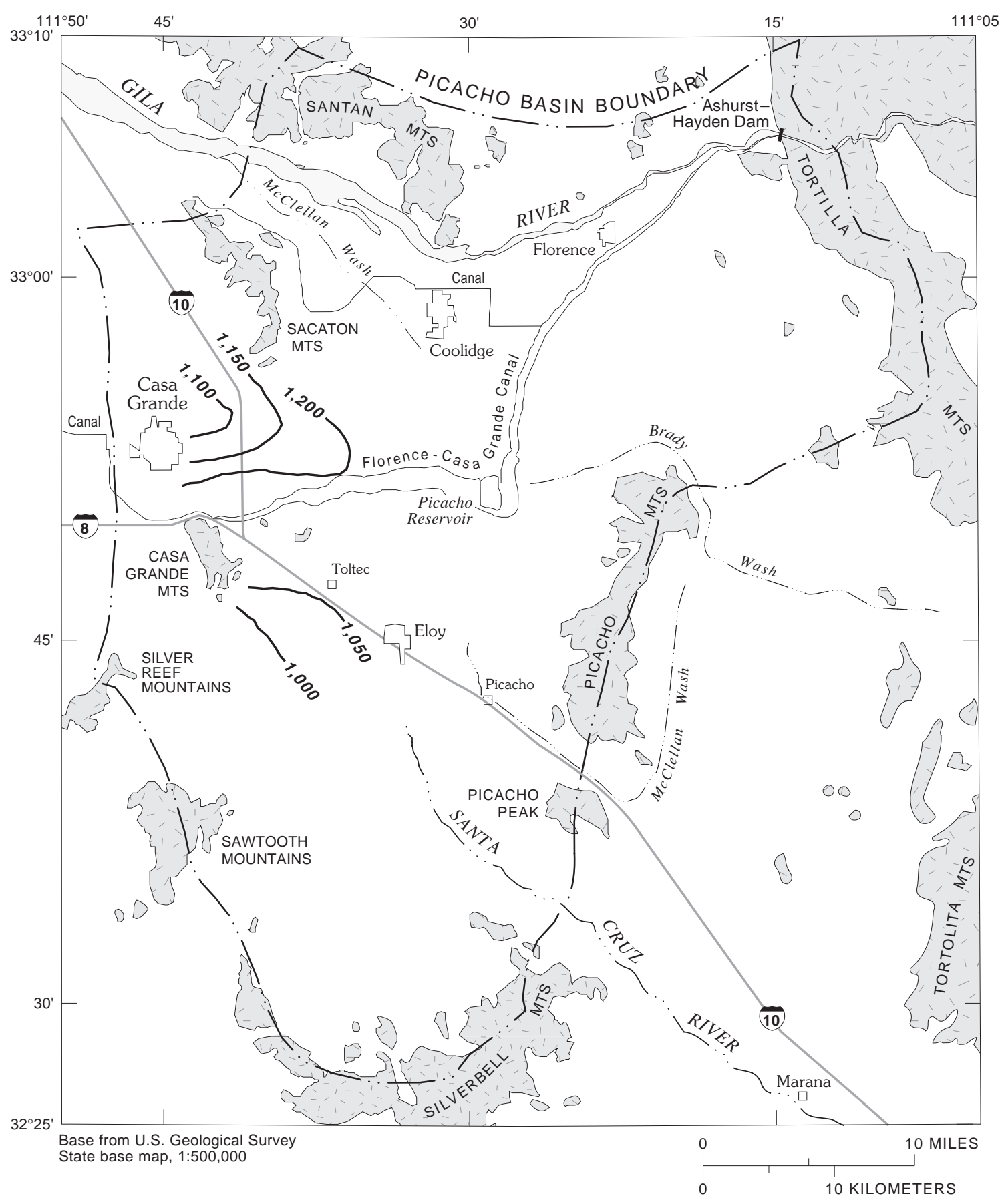

EXPLANATION

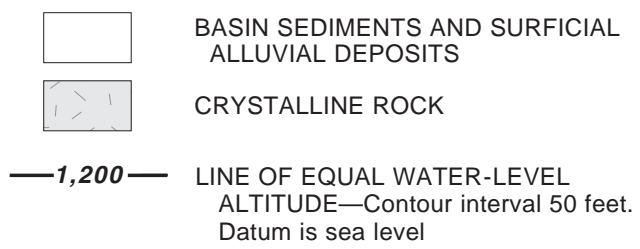

Figure 26. Water-level altitude for 1985 in the lower aquifer system in the western part of Picacho Basin, Arizona. 


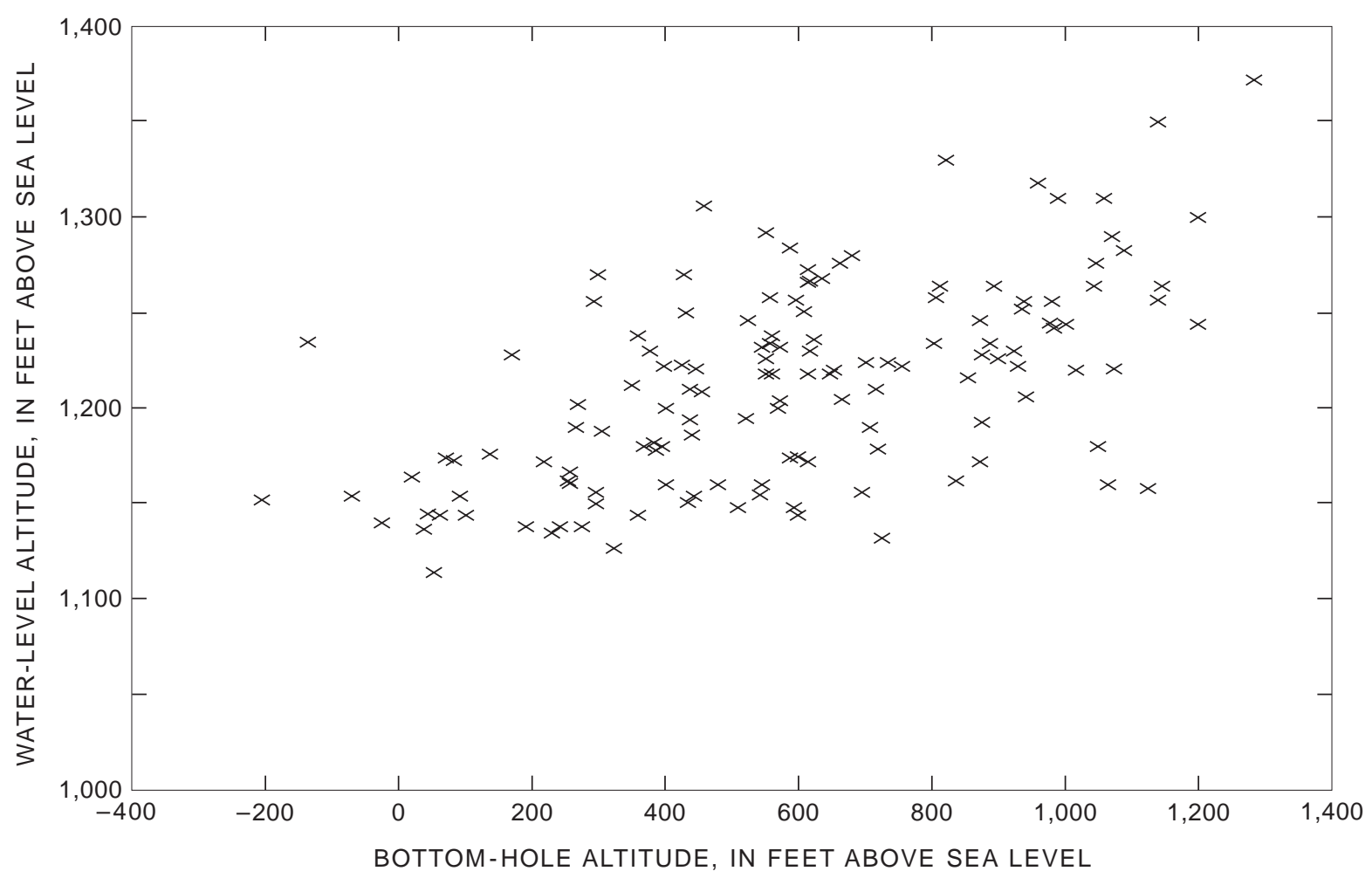

Figure 27. Water-level altitude for 1985 and bottom-hole altitude for wells in the Eloy area.

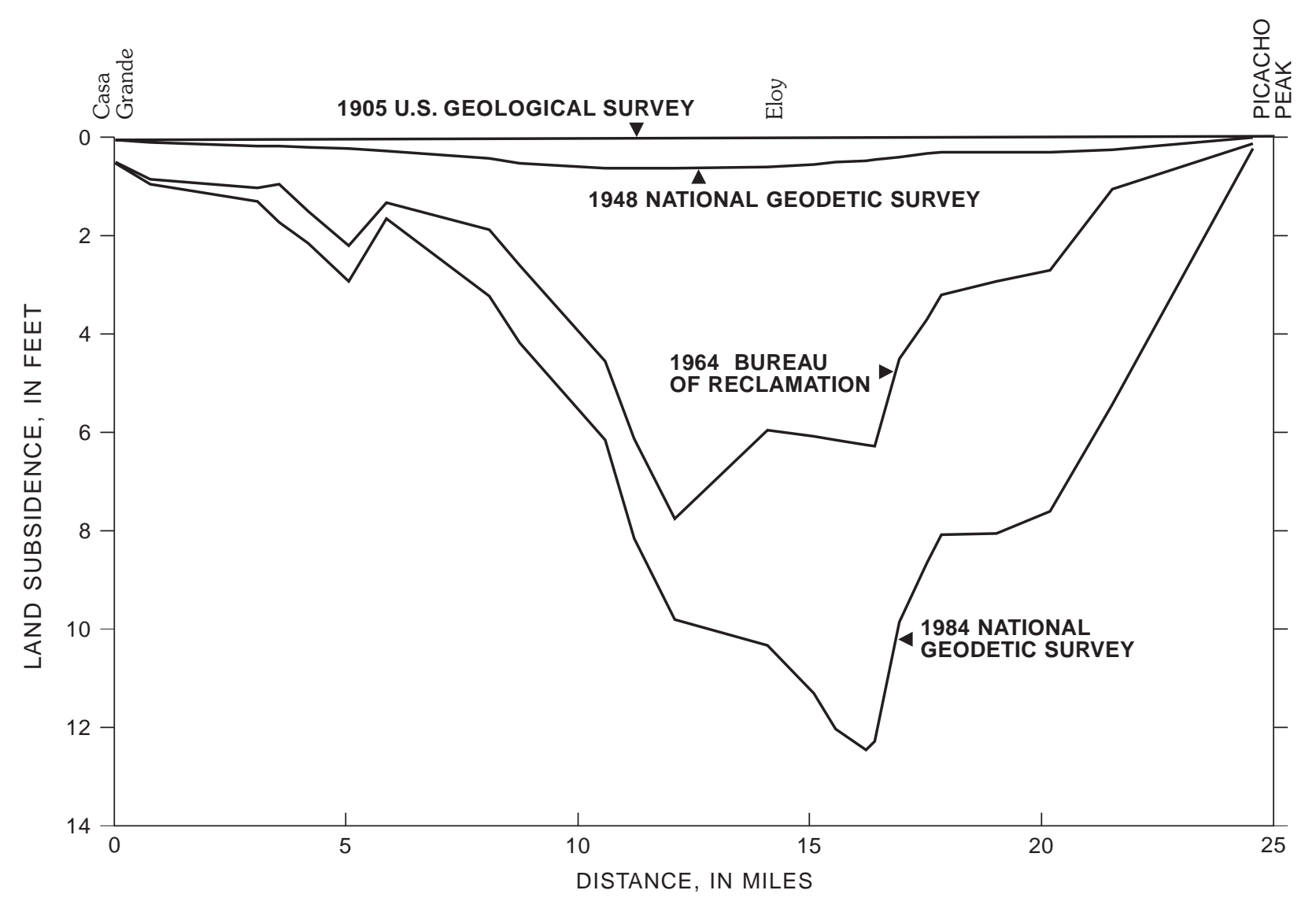

Figure 28. Land subsidence along the primary level line, 1905-84. 
Natural sediment compaction occurs when stresses on the sediment increase as the mass of overlying sediment increases or as water levels decline. Deposition on the alluvial fan of the Santa Cruz River in the southern part of the basin is a potential source of increased load on the existing sediments in Picacho Basin. Natural compaction caused by deposition and increasing stress probably was occurring at a slow rate before development. Under these conditions, the stress on sediments probably was close to preconsolidation stress, and any further stresses, such as reduced hydrostatic stress, would result in inelastic compaction. The occurrence of the first known earth fissure in Picacho Basin soon after the installation of wells near Eloy (Leonard, 1929) and before significant water-level declines indicates that predevelopment stress conditions in some sediments may have been close to values of preconsolidation stress.

Subsurface dissolution of gypsum and halite occurs where the flow of ground water dissolves and transports the minerals downgradient. Natural subsidence of the land surface caused by gypsum and halite dissolution has been documented in several areas (Allen, 1984). Solution commonly occurs along the margins of salt deposits. The occurrence of some natural subsidence in Picacho Basin caused by the dissolution of gypsum or halite is possible. Natural depressions of the land surface existed before development at Picacho Reservoir and at "lake in the desert" at the southern extent of the Sacaton Mountains (Lee, 1904). Both depressions are on the east and west margins of the basin, respectively, and adjacent to the margins of known gypsum deposits (fig. 11).

Dissolution of halite in the subsurface is supported by the predevelopment occurrence of sodium chloride water near Casa Grande (Lee, 1904), which is downgradient from known halite deposits. Lee (1904) also documented the predevelopment occurrence of surficial deposits of sodium chloride northwest of Casa Grande. Natural subsidence caused by dissolution of gypsum and halite probably occurs at a slow rate and should be minor in contrast to measured rates of subsidence in Picacho Basin.

Phase change of calcium sulfate from gypsum to the more dense anhydrite form could occur in the basin. The major areas of subsidence, however, do not correlate with the occurrence of gypsum; therefore, subsidence caused by gypsum-anhydrite conversion probably is insignificant.
Subsurface flow of halite may occur in response to changes in stress at depth if a differential stress of $853 \mathrm{lb} / \mathrm{in}^{2}$ exists within the halite layer (Parker and McDowell, 1955). The required differential pressure could occur if a sediment- thickness differential of about 2,000 ft exists above the halite layer.

This condition could occur if a continuous halite layer exists between well 74, where the top of the halite is found at an altitude of $383 \mathrm{ft}$ above sea level and the projected altitude of the top of the halite-bearing lower unit, which is less than -1,500 ft below sea level and in the area south of Eloy. Any land-surface deformation from such flow would occur slowly and probably is insignificant when compared with the rates of subsidence that have been measured in Picacho Basin.

Tectonic activity within the last 4 m.y. has been documented by the dating of fault scarps in several basins in southern Arizona (Scarborough and others, 1986). Some of the fissures in Picacho Basin could be coincident with pre-existing faults; however, no seismic activity has been detected in the basin and no evidence indicates that any fissures predate ground-water withdrawal.

\section{Water Budget}

Components of the ground-water budget for Picacho Basin include recharge, discharge, underflow, and ground-water storage. A balance between recharge and discharge is assumed to have existed during predevelopment, and no changes in ground-water storage were occurring. The water budget changed during postdevelopment because of agricultural and irrigation practices, which resulted in different distributions of recharge, discharge, and underflow. The post-development water budget is dominated by withdrawal of ground water greatly in excess of recharge that resulted in removal of water from groundwater storage and changes in rates of underflow. Redistribution of Gila River flow has resulted in increased recharge through infiltration along irrigationdistribution canals and decreased recharge along the Gila River. An additional recharge source developed through deep percolation of excess irrigation water. Ground-water flow components estimated by this and other studies are given in table 2. Annual ground-water withdrawals and maximum annual recharge from the three largest sources-deep percolation of excess irrigation water, losses along irrigation-distribution canals, and infiltration along the Gila River-are shown in figure 29. 
Table 2. Comparison of ground-water flow components during early development

[Values are in acre-feet per year. Dashes indicate no data]

\begin{tabular}{|c|c|c|c|c|c|c|c|}
\hline \multirow{2}{*}{$\begin{array}{c}\text { Flow } \\
\text { component }\end{array}$} & \multirow[b]{2}{*}{ Location } & \multicolumn{2}{|c|}{ This project } & \multirow{2}{*}{$\begin{array}{c}\text { Hardt and } \\
\text { Cattany (1965) }\end{array}$} & \multirow{2}{*}{$\begin{array}{l}\text { Thomsen and } \\
\text { Eychaner } \\
\text { (1991) }\end{array}$} & \multicolumn{2}{|c|}{ Turner and others (1943) } \\
\hline & & Maximum & Minimum & & & Maximum & Minimum \\
\hline \multicolumn{8}{|c|}{ Inflow } \\
\hline \multirow[t]{4}{*}{ Underflow } & Picacho Peak-Silverbell Mountains & 23,000 & 20,000 & 25,000 & 19,000 & 24,000 & 23,000 \\
\hline & Picacho Peak-Picacho Mountains & 8,000 & 4,000 & --- & --- & --- & --- \\
\hline & North of Picacho Mountains & 11,000 & 5,500 & 22,000 & --- & 2,500 & --- \\
\hline & Aguirre Valley & --- & --- & --- & --- & 2,500 & --- \\
\hline \multirow[t]{5}{*}{ Recharge } & Gila River & 23,000 & --- & --- & --- & --- & --- \\
\hline & Santa Cruz River & 120,000 & --- & --- & 23,000 & 16,000 & --- \\
\hline & Canals & ${ }^{1} 26,000$ & --- & --- & --- & --- & --- \\
\hline & McClellan Wash & --- & --- & --- & --- & 2,000 & --- \\
\hline & Other streams & ${ }^{2} 1,000$ & --- & --- & --- & --- & --- \\
\hline \multicolumn{8}{|c|}{ Outflow } \\
\hline \multirow[t]{3}{*}{ Underflow } & Gila River & 15,000 & 8,500 & --- & --- & --- & --- \\
\hline & Casa Grande & 12,500 & 6,500 & ${ }^{3} 18,000$ & --- & --- & --- \\
\hline & South of Casa Grande Mountains & 15,750 & 12,600 & --- & --- & --- & --- \\
\hline $\begin{array}{l}\text { Surface-flow } \\
\text { discharge }\end{array}$ & Gila River & --- & --- & --- & 2,600 & --- & --- \\
\hline $\begin{array}{l}\text { Evapotrans- } \\
\text { piration }\end{array}$ & Gila River & --- & --- & --- & 23,000 & --- & --- \\
\hline
\end{tabular}

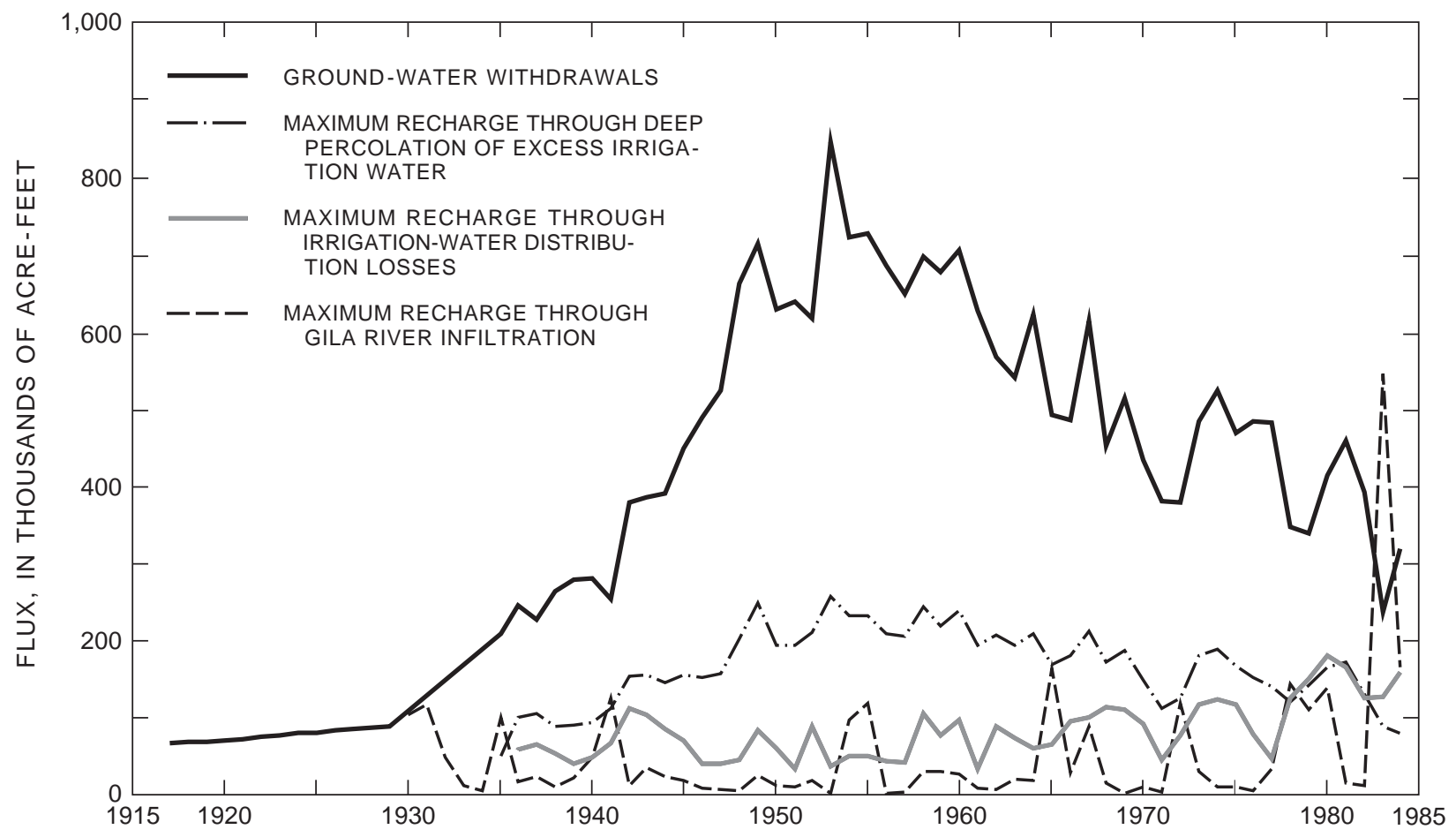

Figure 29. Major water-budget components, 1915-84. 
Recharge.-The major recharge source during predevelopment was streamflow infiltration along the Gila River. Minor recharge sources included the Santa Cruz River, McClellan Wash, and other streams that drain the mountains. Recharge to the postdevelopment ground-water system included infiltration of streamflow in the Gila River, Santa Cruz River, and McClellan Wash. Additional recharge sources developed with agriculture including infiltration along the irrigation-distribution system and deep percolation of excess irrigation water.

Flows in the Gila River that pass the AshurstHayden Dam are available for recharge through streambed infiltration. The actual quantity of recharge that occurs within Picacho Basin can be estimated only as a quantity smaller than flow past Ashurst-Hayden Dam because outflow at the west margin of the basin is not measured. Normally, all the flow within Picacho Basin is lost to infiltration and evaporation from the stream and streambed; however, large flows traverse the basin. Most of the infiltrating water is available for recharge to the aquifer.

Thomsen and Eychaner (1991) estimated that recharge along the Gila River during early development averaged about 23,000 acre-ft/yr (table 2). Turner and others (1943) estimated a recharge rate of 16,000 acre$\mathrm{ft} / \mathrm{yr}$ for 1934-42. Actual annual recharge probably varies greatly coincident with variations in river flow.

Maximum amounts of annual recharge along the Gila River during postdevelopment are indicated by flow past Ashurst-Hayden Dam (fig. 29). Flows before 1965 typically were less than 30,000 acre-ft/yr, and only 3 years had flows that were greater than 100,000 acre-ft. Losses of 240,000 acre-ft were measured during the flood in fall 1983 and winter 1984 between Ashurst-Hayden Dam and Laveen, which is $60 \mathrm{mi}$ downstream from the dam. Estimates of streamflow losses within Picacho Basin from the flood are 120,000 acre- $\mathrm{ft}$ on the basis of losses of 4,000 acre$\mathrm{ft} / \mathrm{mi}$ (Konieczki and Anderson, 1990). This large variation in annual flow indicates that recharge through stream infiltration along the Gila River can vary greatly from less than 2,000 acre-ft/yr to more than $100,000 \mathrm{acre}-\mathrm{ft} / \mathrm{yr}$. The frequency of large flows increased after 1965 when 7 years had flow of more than 100,000 acre-ft. The least flow on record, which was less than 2,000 acre-ft in 1969, however, also occurred during this period. During 1978-84, more than 1,100,000 acre-ft flowed past the dam for an average of more than 160,000 acre-ft/yr.
Davis (1897a) reported that the entire nonfloodflow of the river was diverted near AshurstHayden Dam in 1895, and 64,444 acre-ft was diverted to the Florence Canal for the irrigation of 6,472 acres in 1896. The diversion of Gila River flow caused a redistribution of recharge and reduced downstream flows. Much of the diverted water was lost to evaporation and seepage along the canals. About 10 acre-ft of water was diverted for every acre irrigated. By comparison, in 1985, water use along the Salt River north of the study area was 4.6 acre-ft/acre (Davis, 1897a). Considering that crop use was similar in Picacho Basin and Salt River Valley, at least 32,000 acre-ft were lost to evaporation and seepage along the canals and at Picacho Reservoir. Maximum potential evaporation in the area is about $7 \mathrm{ft}$, and maximum surface area of water in the canals and the reservoir is about 800 acres. Maximum potential evaporation from canals and the reservoir, therefore, is about 5,600 acre-ft/yr. Accordingly, at least 26,400 acre-ft was lost to the ground through seepage.

Early diversions may not have reduced recharge significantly along the river because flows remained high for most years of early development and large flows, which are the main recharge sources, were not diverted. The most significant effect of early diversions was to more than double the quantity of recharge to the northern part of the basin through seepage along canals and at Picacho Reservoir.

Turner and others (1943) estimated that recharge along McClellan Wash was 2,000 acre-ft/yr (table 1). Recharge from infiltration along the Santa Cruz River probably is small because of infrequent flows, evapotranspiration, and the presence of fine-grained sediments in the near surface. Smith (1940) reported that during the floods of August and September of 1939, floodwater spread out across 40,000 to 50,000 acres and provided little more than a good irrigation. Some of the floodwater was used for crop irrigation, which may have caused a reduction in pumpage of 2,000 acre-ft. Flows of similar magnitude are known to have occurred only two other times during 1900 to 1985 - in 1962 and 1983.

Recharge through infiltration along streams that drain the mountains is estimated to be about 1,000 acre- $\mathrm{ft} / \mathrm{yr}$ (table 2) using an equation developed for estimating mountain-front recharge on the basis of precipitation (Anderson, 1986). The equation estimates rates of mountain-front recharge according to the annual volume of precipitation greater than 8 in. 
Average annual precipitation in the basin is about $8.5 \mathrm{in}$. Slightly larger amounts of precipitation may occur in the mountains, but the area and relief of the mountains are small and are presumed to contribute little to the overall volume of precipitation. Recharge along these minor streams is small compared to other recharge sources and is smaller than ranges of error in the estimate of some recharge sources.

Infiltration along San Carlos Irrigation Project canals in the northern part of the basin is a major source of recharge during postdevelopment. Maximum amounts of recharge from this source are estimated from distribution-system losses, which include evaporation from the water surface and infiltration through the bottom of the canals and reservoir. Reported losses in the system generally were less than $100,000 \mathrm{acre}-\mathrm{ft} / \mathrm{yr}$ before 1965 , but were more than 100,000 acre-ft/yr for 1965-83 (fig. 29). The maximum surface area in the canals and at Picacho Reservoir is about 300 and 800 acres, respectively. Maximum potential evaporation from the distribution system at a rate of $7 \mathrm{ft} / \mathrm{yr}$, therefore, is $7,700 \mathrm{acre}-\mathrm{ft} / \mathrm{yr}$, or less than 8 percent of the losses. The actual amount of evaporation could be considerably less because water in the system varies seasonally and the reservoir is often dry. Water available for recharge to the aquifer through infiltration along San Carlos Irrigation Project canals (fig. 29), therefore, is more than 92 percent of the distribution-system losses. Actual amounts could be less because of evapotranspiration or losses to the unsaturated zone.

Quantities of recharge through deep percolation of excess applied irrigation water are not well known. The rates and amounts of deep percolation probably depend on types of near-surface sediments. Finegrained sediments allow less deep percolation than sandy sediments. Estimates of the maximum quantity of excess irrigation water lost to deep percolation are available for lands serviced by the San Carlos Irrigation Project. An average of about 32 percent of the water delivered by the project since 1936 is in excess of crop requirements and, therefore, available for deep percolation. This percentage probably represents the maximum quantity of water available for deep percolation throughout the basin. The San Carlos Irrigation Project lands are irrigated with surface water, and irrigation practices generally do not need to be as efficient as in other parts of the basin. Also, a greater percentage of fine-grained soils probably exists in other parts of the basin. These two factors indicate that irrigation practices probably are more efficient on nonSan Carlos Irrigation Project lands, and less than 32 percent of the applied irrigation water is available for deep percolation. Maximum quantities of annual recharge through deep percolation of excess irrigation water (fig. 29) are estimated as the sum of 32 percent of ground-water withdrawals for non-San Carlos Irrigation Project lands and 32 percent of water delivered to project land.

Discharge.-Discharge from the predevelopment ground-water system occurred as evapotranspiration and flow from the aquifer to the Gila River. The main discharge component of the postdevelopment groundwater budget is withdrawals. Discharge to the Gila River and evapotranspiration gradually decreased with time as water levels declined. Thomsen and Eychaner (1991) estimated 23,000 acre-ft/yr of evapotranspiration and 2,600 acre-ft/yr of aquifer discharge to the Gila River near Coolidge (table 2). Evapotranspiration gradually decreased as water levels declined to more than $30 \mathrm{ft}$ below the land surface. Depths to water of $30 \mathrm{ft}$ or more along the Gila River occurred after 1942 on the basis of water-level maps by Hardt and Cattany (1965).

Well withdrawal of ground water is the dominant source of discharge from the postdevelopment groundwater system. Annual volumes of ground water withdrawn from the basin (fig. 29) are estimated from electrical and gas power-consumption reports, annual ground-water reports of the USGS, and irrigation reports of the San Carlos Irrigation Project. Before 1929, annual withdrawals were less than 100,000 acre-ft. Withdrawals increased from 140,000 to 380,000 acre-ft/yr from 1940 to 1951 . Withdrawals increased to more than 700,000 acre-ft/yr in the early 1950s and gradually decreased after the mid-1950s to a low of about 240,000 acre-ft/yr in 1983.

Underflow.-Underflow is the volumetric flow rate of water entering or leaving the basin-inflow and outflow-through aquifers that are in common with adjacent basins. Rates of underflow increase with greater hydraulic gradient, larger cross-sectional area of aquifer, and higher hydraulic conductivity. The main inflow area is between Picacho Peak and the Silverbell Mountains. Lesser quantities of inflow probably occurred north of the Picacho Mountains and between Picacho Peak and the Picacho Mountains. Small quantities of inflow could have occurred in areas between the Silverbell and Sawtooth Mountains and between the Sawtooth and Silver Reef Mountains. 
Flow rates would have been low because of small aquifer thicknesses and low hydraulic gradients. Major outflow areas are between the Silver Reef and Casa Grande Mountains, between the Casa Grande and Sacaton Mountains, and between the Sacaton and Santan Mountains.

Estimates of annual underflow for predevelopment conditions at inflow and outflow areas have been made by several investigators (table 2). Values of underflow calculated for this project are based on the estimated thickness and hydraulic properties of the hydrostratigraphic units. Maximum and minimum underflow rates are based on ranges of possible hydraulic gradient, hydraulic conductivity, and thickness presented in this report. Estimates of inflow between Picacho Peak and the Silverbell Mountains range from 19,000 to 25,000 acre-ft/yr. Additional inflow of 4,000 to 8,000 acre-ft/yr is estimated between Picacho Peak and the Picacho Mountains. Previous estimates of inflow north of the Picacho Mountains ranged from 2,500 acre-ft/yr (Turner and others, 1943) to 22,000 acre-ft/yr (Hardt and Cattany, 1965); estimates for this project are 5,500 to 11,000 acre- $\mathrm{ft} / \mathrm{yr}$. Outflow south of the Casa Grande Mountains was estimated to be 5,000 acre-ft/yr (Turner and others,
$1943) ; 12,600$ to 15,750 acre-ft/yr was estimated for this project. This study estimated from 6,500 to 12,500 acre-ft/yr of outflow at Casa Grande and 8,500 to 15,500 acre-ft/yr of outflow beneath the Gila River (table 3).

Discharge through underflow to adjacent aquifers in basins to the west of the study area began diminishing as water levels in the basin declined and caused reversals of hydraulic gradients at those underflow areas. Ground-water divides resulted at the boundary between the basins as pre-existing gradients persisted west of the divides and gradients toward the center of Picacho Basin developed east of the divides. The timing of development of these ground-water divides can be estimated from water-level-altitude maps for 1942, 1949, 1959, and 1964 produced by Hardt and Cattany (1965). Outflow of less than 16,000 acre-ft/yr south of the Casa Grande Mountains and less than 12,500 acre-ft/yr at Casa Grande probably were eliminated by 1949 . Outflow of less than 15,500 acre-ft/yr beneath the Gila River may not have been entirely eliminated by 1985 , according to water levels presented by Wickham and Corkhill (1989).

Table 3. Ground-water budget components for selected periods

[Values are in thousands of acre-feet]

\begin{tabular}{|c|c|c|c|c|c|c|c|c|c|}
\hline \multicolumn{3}{|c|}{ Outflow } & \multicolumn{5}{|c|}{ Inflow } & \multicolumn{2}{|c|}{ Ground-water storage } \\
\hline Period & Pumpage $^{1}$ & $\begin{array}{c}\text { Other } \\
\text { discharge }^{2}\end{array}$ & $\begin{array}{c}\text { San Carlos } \\
\text { Irrigation } \\
\text { Project } \\
\text { losses }^{3}\end{array}$ & $\begin{array}{c}\text { Gila River } \\
\text { infiltration } 4\end{array}$ & $\begin{array}{c}\text { Other } \\
\text { natural } \\
\text { recharge }^{5}\end{array}$ & $\begin{array}{c}\text { San Carlos } \\
\text { deep } \\
\text { percola- } \\
\text { tion }^{6}\end{array}$ & $\begin{array}{l}\text { Under- } \\
\text { flow } 7\end{array}$ & Change $^{8}$ & $\begin{array}{c}\text { Rate of } \\
\text { change per } \\
\text { year }\end{array}$ \\
\hline $1900-49$ & 7,774 & 1,626 & 1,583 & 2,025 & 245 & 1,852 & 1,604 & $-2,091$ & -43 \\
\hline $1950-59$ & 6,723 & 56 & 511 & 324 & 50 & 1,781 & 385 & $-3,728$ & -376 \\
\hline 1960-64 & 3,710 & 21 & 313 & 242 & 25 & 1,024 & 179 & $-1,948$ & -390 \\
\hline $1965-76$ & 5,215 & 32 & 1,039 & 320 & 60 & 1,355 & 429 & $-2,044$ & -170 \\
\hline $1977-84$ & 2,986 & 5 & 1,078 & 573 & 40 & 665 & 288 & -347 & -43 \\
\hline Total & 26,408 & 1,740 & 4,524 & 3,484 & 420 & 6,677 & 2,885 & $-10,158$ & \\
\hline
\end{tabular}

${ }^{1}$ Estimated from U.S. Geological Survey annual ground-water reports, annual irrigation reports of the San Carlos Irrigation Project, and other publications that describe the pumpage and irrigation history.

${ }^{2}$ Includes linearly decreasing outflow with time and evapotranspiration along Gila River for the period before 1950

${ }^{3}$ Estimations of main canal losses and losses to deep percolation reported by the San Carlos Irrigation Project corrected for evaporation of 7,700 acre-feet per year

${ }^{4}$ Estimated from flow past Ashurst-Hayden Dam. Represents all flow past Ashurst-Hayden Dam and a maximum amount of potential infiltration for the period prior to 1983. Estimated as 120,000 acre-feet for the period 1983-84.

${ }^{5}$ Estimated as 5,000 acre-feet per year, includes infiltration of runoff in Santa Cruz River, McClellan Wash, and other washes that drain the surrounding mountains.

${ }^{6}$ Estimated as 30 percent of non-San Carlos Irrigation Project pumpage.

${ }^{7}$ Estimated as a constant rate of underflow since predevelopment.

${ }^{8}$ Calculated as the residual of inflow and outflow components. 
Storage. - Change in ground-water storage for 1900-49, 1950-59, 1960-64, 1965-76, and 1977-84 is calculated as a residual of other estimated water-budget components (table 3). Calculations assume no change in underflow into the basin. Changes in underflow out of the basin and evapotranspiration were decreased linearly with time as the discharge component was eliminated. Sources of recharge are the least known water-budget components; therefore, each source of recharge is estimated as a maximum possible quantity for the purpose of consistency. Recharge through infiltration of San Carlos Irrigation Project losses is estimated as all measured losses along the distribution system plus maximum losses to deep percolation. Recharge through infiltration of Gila River flow is estimated as all flow past Ashurst-Hayden Dam with the exception of 1983-84, which is estimated as 120,000 acre-ft. Deep percolation of excess applied irrigation water on non-San Carlos Irrigation Project land is estimated as 30 percent of ground-water withdrawals. Change in ground-water storage, calculated as the residual of inflow and outflow, is a minimum value because the primary inflow components are estimated as maximum values. The minimum change in ground-water storage for $1900-84$ is 11,791,000 acre-ft. Minimum rates of change in ground-water storage are greatest-more than 370,000 acre-ft/yr-for 1950-64. Later minimum rates of change in ground-water storage are considerably less, about 170,000 acre-ft/yr for 1965-76 and 44,000 acre-ft/yr for 1977-84.

\section{Hydraulic Properties of the Aquifer System}

Hydraulic properties of the aquifer system are physical characteristics that describe the ability of the system to transmit water and include hydraulic conductivity and transmissivity. Hydraulic conductivity is the basic property that describes the rate of ground-water flow and is defined as the volume rate of movement of water at the prevailing viscosity through a unit area of aquifer under a unit hydraulic-head gradient. Transmissivity is the rate at which water is transmitted through a unit thickness of an aquifer under a unit-hydraulic gradient (Lohman, 1979). Hydraulic properties were estimated for each of the hydrostratigraphic units in the basin.

Hydraulic conductivity and transmissivity were estimated through indirect means. Three methods have been used to estimate hydraulic conductivity in alluvial aquifers in Arizona. The methods use available data from specific-capacity tests and grain-size analyses. Several studies have established that transmissivity (in units of feet squared per day) is about 270 times the specific-capacity value (in gallons per minute per foot of drawdown) for alluvial aquifers in central Arizona (Anderson, 1968; Niccoli and Long, 1981; Brown and Pool, 1989). Data from aquifer tests and grain-size analyses of well-drilling samples were used to develop a relation between hydraulic conductivity and average grain size for the middle unit in the eastern part of the Salt River Valley (Laney and Hahn, 1986). These methods were applied in Picacho Basin to produce general estimates of hydraulic conductivity and transmissivity distributions.

The relation of hydraulic conductivity to grain size developed for the middle unit in the eastern part of the Salt River Valley may be applicable to the upper unit in Picacho Basin because the two units are correlative and lithologically similar. A curvilinear relation between hydraulic conductivity and percent sand and gravel for the middle unit in the Salt River Valley resulted in the greatest hydraulic conductivity of about $100 \mathrm{ft} / \mathrm{d}$ occurring at 80 percent sand and gravel and the lowest hydraulic conductivity of about $20 \mathrm{ft} / \mathrm{d}$ occurring at less than 20 percent sand and gravel (Laney and Hahn, 1986). The largest increase in hydraulic conductivity occurred between 50 and 70 percent sand and gravel where values increased from about $40 \mathrm{ft} / \mathrm{d}$ to more than $80 \mathrm{ft} / \mathrm{d}$, respectively.

The average grain-size distribution in the alluvial facies of the upper and middle units-upper aquifer system-of Picacho Basin ranges from 30 to 70 percent sand and gravel at 54 well locations but predominantly ranges from 40 to 60 percent sand and gravel.

Application of the relation from the East Salt River Valley indicates that the hydraulic conductivity for most of the alluvial facies of the upper unit ranges from 30 to $60 \mathrm{ft} / \mathrm{d}$; the lower range of values occurs in fine-grained sediments southwest of Eloy and south of Coolidge. Higher values of 70 to $100 \mathrm{ft} / \mathrm{d}$ are associated with coarse-grained sediments along the Gila River, south of the Casa Grande Mountains, east of Eloy, and between the Silverbell Mountains and Picacho Peak.

Hydraulic-conductivity values for the playa facies of the middle and lower units and alluvial facies of the lower unit are poorly known but can be estimated on the basis of the relation between hydraulic conductivity and grain size developed in the East and West Salt River Valleys (Laney and Hahn, 1986; Brown and Pool, 
1989). The playa facies of the middle unit is predominantly fine grained-less than 20 percent sand and gravel - but is more dense and less porous than similar sediments in the upper unit; therefore, values of hydraulic conductivity probably are less than $20 \mathrm{ft} / \mathrm{d}$. The playa facies of the lower unit is more dense and less porous than the middle unit; therefore, lower values of hydraulic conductivity are likely.

The conglomerate of the lower unit is similar to conglomerate found in the western part of the Salt River Valley, which has hydraulic-conductivity values of about $10 \mathrm{ft} / \mathrm{d}$ (Brown and Pool, 1989).

Hardt and Cattany (1965) studied the specific-capacity distribution in western Pinal County, including Picacho Basin, using data from completion tests of wells that were drilled from 1945 to 1950. The data generally represent the upper unit because more than 75 percent of the wells were less than $600 \mathrm{ft}$ deep and more than 90 percent were less than $800 \mathrm{ft}$ deep. Regions with low transmissivity values-less than $6,750 \mathrm{ft}^{2} / \mathrm{d}$-were in the central part of the basin southwest of Eloy and between Coolidge and Eloy. Transmissivity of greater than $12,000 \mathrm{ft}^{2} / \mathrm{d}$ was found in the Coolidge area and along the Gila River. The highest transmissivity of more than $25,000 \mathrm{ft}^{2} / \mathrm{d}$ was between Picacho Peak and the Silverbell Mountains. Transmissivity values calculated from specific-capacity data probably underestimate the transmissivity for the entire saturated thickness of the upper unit because most wells do not fully penetrate the unit.

Transmissivity values for the upper aquifer system also were estimated using the product of thickness and hydraulic-conductivity values estimated from grainsize data. The resulting values are less than $10,000 \mathrm{ft}^{2} / \mathrm{d}$ in the central parts of the basin, more than $20,000 \mathrm{ft}^{2} / \mathrm{d}$ east of Coolidge, and more than 50,000 $\mathrm{ft}^{2} / \mathrm{d}$ southeast of Eloy. These estimates are greater than the specificcapacity estimates because the entire estimated thickness of the aquifer system is included rather than the thickness penetrated by wells.

\section{Storage Properties of the Aquifer System}

The ability of the aquifer to store water is described by aquifer-storage properties. Most of the water in the aquifer system in Picacho Basin is stored in pore spaces between grains of alluvial sediment. Changes in storage occur primarily through drainage or resaturation of pores and compression or expansion of saturated pores. Compression or expansion of water is an insignificant source of storage.

The basic property of aquifer storage is specific storage, which is defined as the volume of water released from a unit volume of aquifer per unit decline in hydraulic head (Lohman and others, 1972; Freeze and Cherry, 1979). Storage in an unconfined aquifer is expressed as specific yield, which is defined as the volume of water that is released from storage per unit area of aquifer per unit decline in the water table (Lohman and others, 1972; Freeze and Cherry, 1979). In confined aquifers, most water is derived from compaction of pores that includes two componentselastic and inelastic - that result in recoverable and nonrecoverable changes in pore volume, respectively (Poland and others, 1972). Elastic specific storage normally is much smaller than inelastic specific storage, and most water removed from aquifer compaction is derived from inelastic or nonrecoverable storage. The product of specific storage and aquifer thickness is the aquifer-storage coefficient which is defined as the volume of water released from or taken into aquifer storage per unit of surface area of the aquifer per unit change in head (Lohman, 1972).

The spatial distribution of specific yield in unconfined aquifers is highly variable. Most storage changes in the aquifer system have occurred as a result of drainage of pore spaces as water levels in the upper aquifer system have declined more than $300 \mathrm{ft}$. Drainage of pore spaces can occur only in materials, such as sand and gravel, that have well-connected pores. Pore spaces are not well connected in silts and clays and water tends to be retained; therefore, specific-yield values are greater in sediments with a high percentage of sand and gravel.

Significant losses in ground-water storage also have occurred through reduction in pore volume, which is manifested as more than $15 \mathrm{ft}$ of land-surface subsidence (Schumann, 1986). Clay minerals, especially montmorillonite, are significantly more susceptible to compaction and loss of pore volume than are silt, sand, or gravel because clays generally are more porous and compressible (Jorgensen, 1980). Values of specific storage generally are larger in sediments that have a high percentage of clay. Most compaction and loss of pore volume, therefore, probably have occurred within zones that contain large percentages of clay such as the middle confining unit and fine-grained interbeds within the upper aquifer system. 
Specific Yield.-The spatial distribution of specific yield in the aquifer system in Picacho Basin cannot be directly measured because the spatial distribution of the water-table declines and withdrawals from storage are not well known. Basinwide values of specific yield, however, can be estimated for time intervals that have information on changes in groundwater storage and in the water table. Specific yield is calculated by dividing the volume of aquifer that has been dewatered by the net change in ground-water storage. Two assumptions are essential to this calculation. First, all storage change is assumed to occur through drainage of pore spaces in the zone of water-table change. Second, water levels in wells are assumed to be representative of the water table. The quantity of water derived from drainage of pore spaces, estimated as total storage change, is a maximum possible value because the part of storage change lost through reduction in pore volume is ignored. The dewatered volume calculated from water levels in wells represents a maximum value because water levels in wells probably are lower than the level of the water table, especially during the later stages of development.

Basinwide values of specific yield (table 4) were calculated for selected periods using minimum changes in ground-water storage (table 3) and water-leveldecline maps (figs. 20-24). Specific yield for 1900-76 ranges from 8 percent before 1950 to 14 percent for 1950-59 and 12 percent for 1960-76. The method of determining the distribution of water-level decline has a large influence on the value of specific yield calculated for 1977-84. Use of composite water levels from both aquifer systems results in a low specificyield value, 4 percent, because the volume of waterlevel decline is influenced greatly by water levels in the lower aquifer system, which declined more than water levels in the upper aquifer system. Use of water levels in the upper aquifer system in 1984 and composite water levels in 1977 results in a low estimate of the amount of water-level decline and a high specific-yield value of 25 percent. The actual value probably is within the range of the two estimates.

Specific Storage.-Storage properties of the compressible part of the aquifer can be estimated from direct measurements of stress and strain within the aquifer. Storage coefficient is almost linearly related to the ratio of strain to change in effective stress (Riley, 1969; Helm, 1975). Stress-strain relations for aquifer materials, therefore, can be used to estimate values of storage coefficient for a specified stress range. Stress and strain can be measured by monitoring water levels and compaction, respectively, in the aquifer system.

Water-level change represents the change in hydrostatic pressure and change in effective stress provided that no significant change in geostatic load occurs.

Compaction represents strain over the monitored thickness of aquifer. Land subsidence is a measure of compaction over the entire aquifer thickness. Storage coefficient is estimated as the inverse slope of the relation between water-level change and compaction. Specific storage is estimated by dividing the storage coefficient by the thickness of compacting interval.

Table 4. Specific-yield calculations for selected periods

[Values are in thousands of acre-feet]

\begin{tabular}{|c|c|c|c|c|c|c|c|}
\hline Period & $\begin{array}{l}\text { Change in } \\
\text { storage }^{1}\end{array}$ & $\begin{array}{l}\text { Volume of water- } \\
\text { level decline }\end{array}$ & Specific yield & Period & Change in storage ${ }^{1}$ & $\begin{array}{l}\text { Volume of water- } \\
\text { level decline }\end{array}$ & Specific yield \\
\hline $1900-49$ & $-2,091$ & 24,842 & 0.8 & $1965-76$ & $-2,044$ & 19,915 & 0.12 \\
\hline $1950-59$ & $-3,728$ & 31,776 & .14 & 1977-84 & -349 & 7,921 & .04 \\
\hline 1960-64 & $-1,948$ & 16,657 & .12 & 1977-84 & -349 & ${ }^{3} 1,372$ & .25 \\
\hline
\end{tabular}

${ }^{1}$ Sum of recharge and discharge components.

${ }^{2}$ Volume of water-level decline calculated from composite map of upper and lower aquifer-system water levels.

${ }^{3}$ Volume of water-level decline calculated from map of 1984 upper aquifer-system water levels and 1977 map of composite water levels. 
Stress and strain are indicated by measurements of water levels in wells, compaction at a vertical extensometer near Eloy, and subsidence data along the primary level line. Storage coefficients and composite values of specific storage for large thicknesses of aquifer are estimated from these data. Vertical variations in specific storage are inferred from borehole-geophysical logs of aquifer density.

Storage-coefficient values for the compressible part of the aquifer system are determined from waterlevel and subsidence data. Holzer (1981) investigated relations between water-level decline and subsidence for wells near the primary level line near Eloy. Results indicated that the aquifer deformed elastically before water-level declines reached a preconsolidation stress of about $100 \mathrm{ft}$, and deformation occurred inelastically at greater stress. Inelastic storage-coefficient values presented by Holzer (1981) are $3.73 \times 10^{-2}$ to $5.31 \times 10^{-2}$; elastic values ranged from $0.91 \times 10^{-3}$ to $5.38 \times 10^{-3}$. These values are considered to represent maximum values of storage coefficient because the water levels represent conditions that existed after recovery from seasonal pumping levels and probably are not indicative of maximum stresses. Stress-strain plots of water levels in wells (D-08-08)10cdd, (D-08-08)5cdd, (D-07-07)26ddd, and (D-07-07)34cdd and subsidence along the primary level line (figs. 18 and 30) indicate a linear relation between subsidence and stresses greater than the preconsolidation stress. An average inelastic-storage coefficient of $5 \times 10^{-2}$ is calculated from the inverse of the linear stress- strain relation for each well. The thickness of the upper and middle units that compose the compressible aquifer at the wells ranges from about $1,000 \mathrm{ft}$ to $2,500 \mathrm{ft}$. Division of the storage coefficient by the thickness of compressible aquifer-system results in average specific-storage values that range from $2 \times 10^{-5} \mathrm{ft}^{-1}$ to $5 \times 10^{-5} \mathrm{ft}^{-1}$.

Storage coefficients can be estimated from stressstrain relations that have been monitored at a vertical extensometer, well 77, near Eloy since 1965 (figs. 6 and 18). Water levels and compaction are monitored in $525 \mathrm{ft}$ of sediments within the upper aquifer system including $196 \mathrm{ft}$ of confining beds and the upper $82 \mathrm{ft}$ of the middle confining unit. More than $2.5 \mathrm{ft}$ of compaction was measured through 1983 (fig. 31). Water levels varied by more than $100 \mathrm{ft}$ on a seasonal basis, and the maximum depth to water increased by more than $50 \mathrm{ft}$ throughout the period of record. Water- level data were affected by air-line leaks during the winters of 3 years near the end of the record. The inverse slope of the line AB represents an elasticstorage coefficient of $1.7 \times 10^{-3}$. The inverse slope of line $\mathrm{CD}$ represents an inelastic-storage coefficient of $4.3 \times 10^{-2}$. Average elastic specific storage for the monitored thickness is $3.2 \times 10^{-6} \mathrm{ft}^{-1}$. Average inelasticspecific storage is $8.2 \times 10^{-5} \mathrm{ft}^{-1}$. The average specific storage for the confining beds is $6.1 \times 10^{-6} \mathrm{ft}^{-1}$ and $1.5 \times 10^{-4} \mathrm{ft}^{-1}$ for the elastic and inelastic ranges, respectively, assuming compaction occurs only within the $278 \mathrm{ft}$ of confining beds.

A one-dimensional compaction model was used to simulate aquifer compaction at the extensometer (Epstein, 1987). Specific-storage values used in the model to represent seven compressible layers ranged from $2.4 \times 10^{-6} \mathrm{ft}^{-1}$ to $3.0 \times 10^{-6} \mathrm{ft}^{-1}$ for the elastic range and $1.5 \times 10^{-4} \mathrm{ft}^{-1}$ to $2.7 \times 10^{-4} \mathrm{ft}^{-1}$ for the inelastic range.

An average specific-storage value for the area along the primary level line was calculated by dividing the cross-sectional area of accumulated subsidence by the cross-sectional area of compressible aquifer and the average stress. The area of compressible aquifer was estimated on the basis of the altitude of the base of the middle hydrostratigraphic unit and altitude of the water level. Average stress was estimated from water-level declines. The average specific storage for the entire length of the primary level line was calculated for 1905-48, 1948-64, and 1964-77. The average specific-storage value for compaction for 1905-48 resulted in a value of $7.2 \times 10^{-6} \mathrm{ft}^{-1}$, which is primarily a value for the elastic range. Inelastic-specific storage for 1948-64 and 1964-77 was $2.7 \times 10^{-5} \mathrm{ft}^{-1}$ and $4.5 \times 10^{-5} \mathrm{ft}^{-1}$, respectively. The apparent increase in specific storage with time probably is caused by stresses that are greater than those indicated by annual water levels and stresses that are occurring throughout greater thicknesses of compressible sediments with time. Water levels measured during the irrigation season can be as much as $100 \mathrm{ft}$ lower than those measured during the nonirrigation season as indicated by stress strain at the extensometer (fig. 31). Increased pumping from deep wells with time probably has resulted in greater stress at depth in the aquifer and increased stress on previously unaffected sediments. 


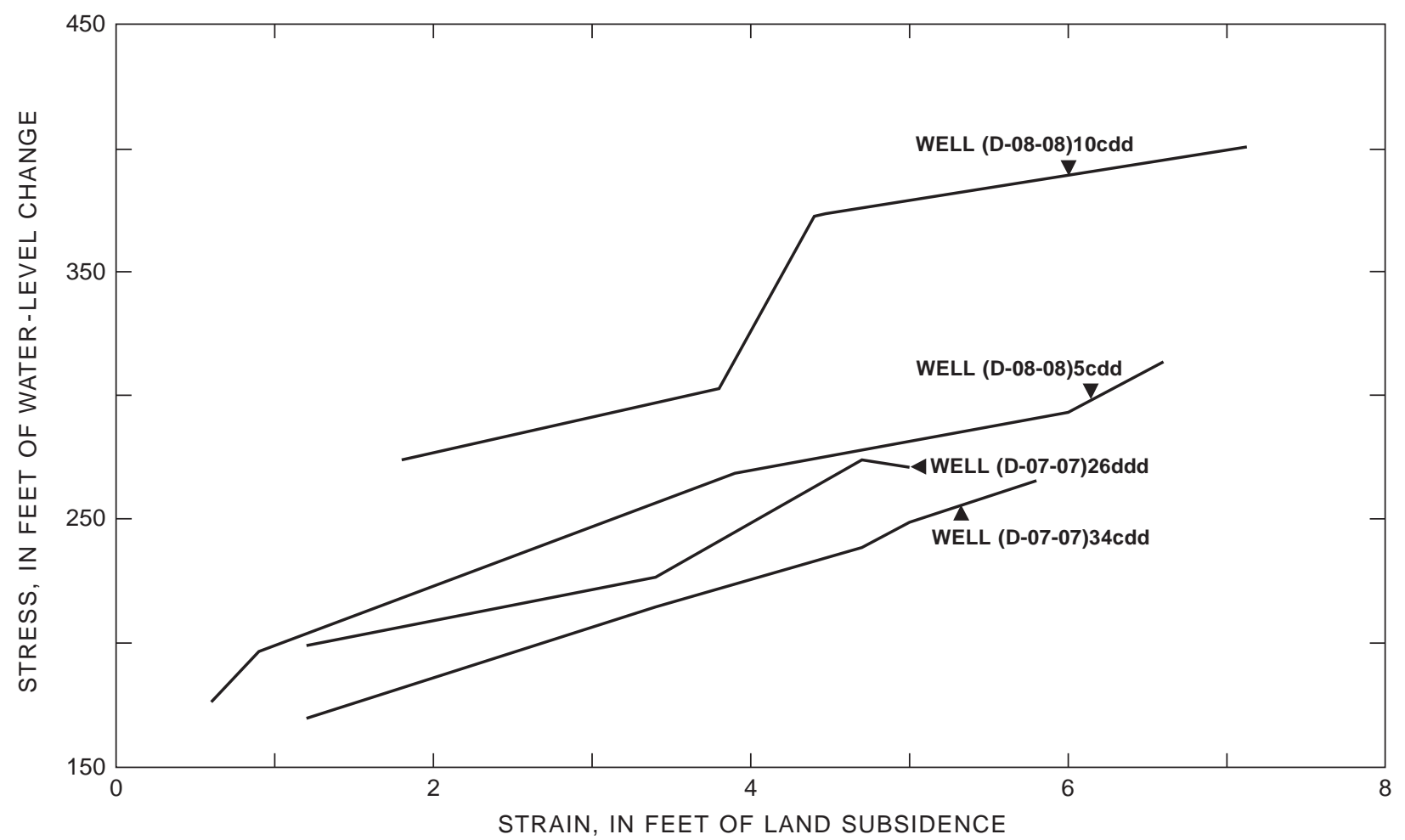

Figure 30. Stress-strain relation at the observation wells near the primary level line.

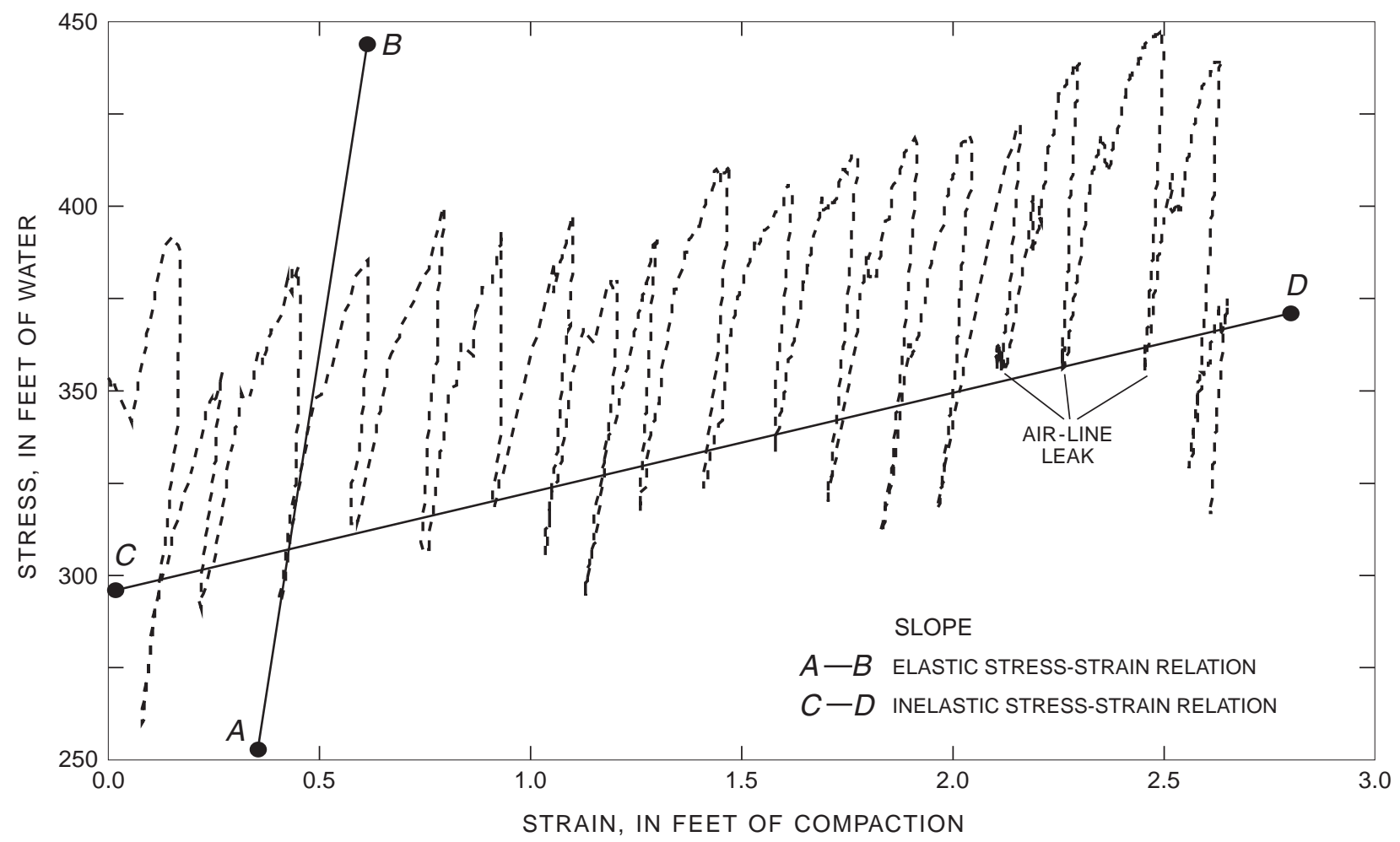

Figure 31. Stress-strain relation at the extensometer near Eloy. See fig. 18 for location of extensometer. 
The vertical distribution of storage properties can be inferred from borehole-density logs provided storage properties exist under preconsolidation head, specific storage is a function of effective stress, and the composition of sediments and grain density do not vary with depth. The equation (Jorgensen, 1980) is

$$
S_{s k}=\frac{0.434 C_{c} \Upsilon_{w}}{s_{z}\left(1+e_{o}\right)},
$$

where

$$
\begin{aligned}
\Sigma_{\sigma \kappa}= & \text { specific storage } \\
\mathrm{X}_{\chi}= & \text { compression index for the aquifer } \\
& \text { materials, } \\
\Upsilon_{\omega}= & \text { unit weight of water, } \\
\sigma_{\zeta}= & \text { effective stress, and } \\
\varepsilon_{0}= & \text { initial void ratio. }
\end{aligned}
$$

Density values are converted to void ratio using an average value of grain density. Effective stress is determined from the density log by summing the geostatic load caused by overlying mass and subtracting the hydrostatic pressure head at any depth. $C_{c}$ for a density sample at any depth is determined using the calculated void ratio, effective stress, and estimated initial conditions of void ratio and effective stress. Specific storage then can be estimated at any depth. Absolute values of specific storage determined by this method may not be correct; however, vertical trends in values can be estimated.

Vertical variations in specific storage of finegrained sediments within the upper and middle hydrostratigraphic units at wells 100 and 105 (fig. 6) were estimated from density logs using equation 2 , an average grain density of $2.72 \mathrm{~g} / \mathrm{cm}^{3}$ determined from analysis of eight core samples from well 77 (Thomas L. Holzer, geologist, USGS, written commun., undated), initial void ratio of 1.0 , and initial stress of $1.0 \times 10^{5}$ pascal (fig. 32). Hydrostatic pressure head was determined from water-level information at the time of drilling and was assumed to increase linearly with depth. Only intervals of fine-grained sediments were used in the analysis; electrical resistivity and neutronporosity logs were used to select intervals with the lowest value of resistivity or highest value of porosity. Several fine-grained intervals occur in the alluvial facies of the upper hydrostratigraphic unit at each well. The playa facies are composed entirely of fine-grained sediments at each well.
Void ratios of fine-grained intervals within the alluvial facies of the upper unit range from 0.70 to 0.90 and have no apparent trend with depth. Values of void ratio within the alluvial facies of the upper unit represent maximum values for the unit because coarsegrained intervals are more dense and less porous. Void ratios are lower within the playa facies of the upper and middle units, and different trends are displayed with depth at each well. Values at well 105 decrease from about 0.70 at the top of the playa facies of the upper unit to about 0.30 at the base of the playa facies of the middle unit. Values at well 100 are more uniform with depth in the playa facies of the middle unit and range from about 0.55 to 0.70 in the upper $500 \mathrm{ft}$ of the unit to about 0.50 to 0.60 in the lower $100 \mathrm{ft}$.

Specific-storage values for the fine-grained intervals of the alluvial facies of the upper unit are similar to those determined by other methods and generally range from about $2.0 \times 10^{-4} \mathrm{ft}^{-1}$ to $4.0 \times 10^{-4} \mathrm{ft}^{-1}$. These values are maximum values for the alluvial facies of the upper unit because other intervals contain more coarse-grained sediments and are less susceptible to compaction. Trends of specific-storage values within the playa facies of the middle unit are the reverse of the trends in void ratio with depth. Values at well 105 are about $3.0 \times 10^{-4} \mathrm{ft}^{-1}$ throughout the thickness of the playa facies of the upper and middle units. Values at well 100 decrease with depth from about $3.5 \times 10^{-4} \mathrm{ft}^{-1}$ near the top of the middle-unit playa facies to about $2.0 \times 10^{-4} \mathrm{ft}^{-1}$ near the base.

The presence of pore pressures within the playa facies greater than those expected from the water level at the time of drilling at well 100 may cause the vertical trends in void ratio and estimated specific storage. Excess pore pressures result in an overestimation of effective stress and underestimation of specific-storage values. Maximum possible excess pore pressures are equivalent to approximate water-level declines that had occurred at the time of drilling-250 ft at well 100 and $300 \mathrm{ft}$ at well 105. Applying the assumption of maximum excess pore pressure in the playa facies at both wells results in large estimated specific-storage values. Excess pore pressures near the base of the playa facies at well 100 result in specific-storage values that are similar to values near the top that were estimated using no excess pore pressure. Excess pore pressures near the base of the playa facies at well 105 result in specific-storage values that are larger than those near the top. A uniform specific-storage value with depth in the playa facies of the middle and upper units is more likely than increasing values with depth because of the general homogeneity of the sediments. 


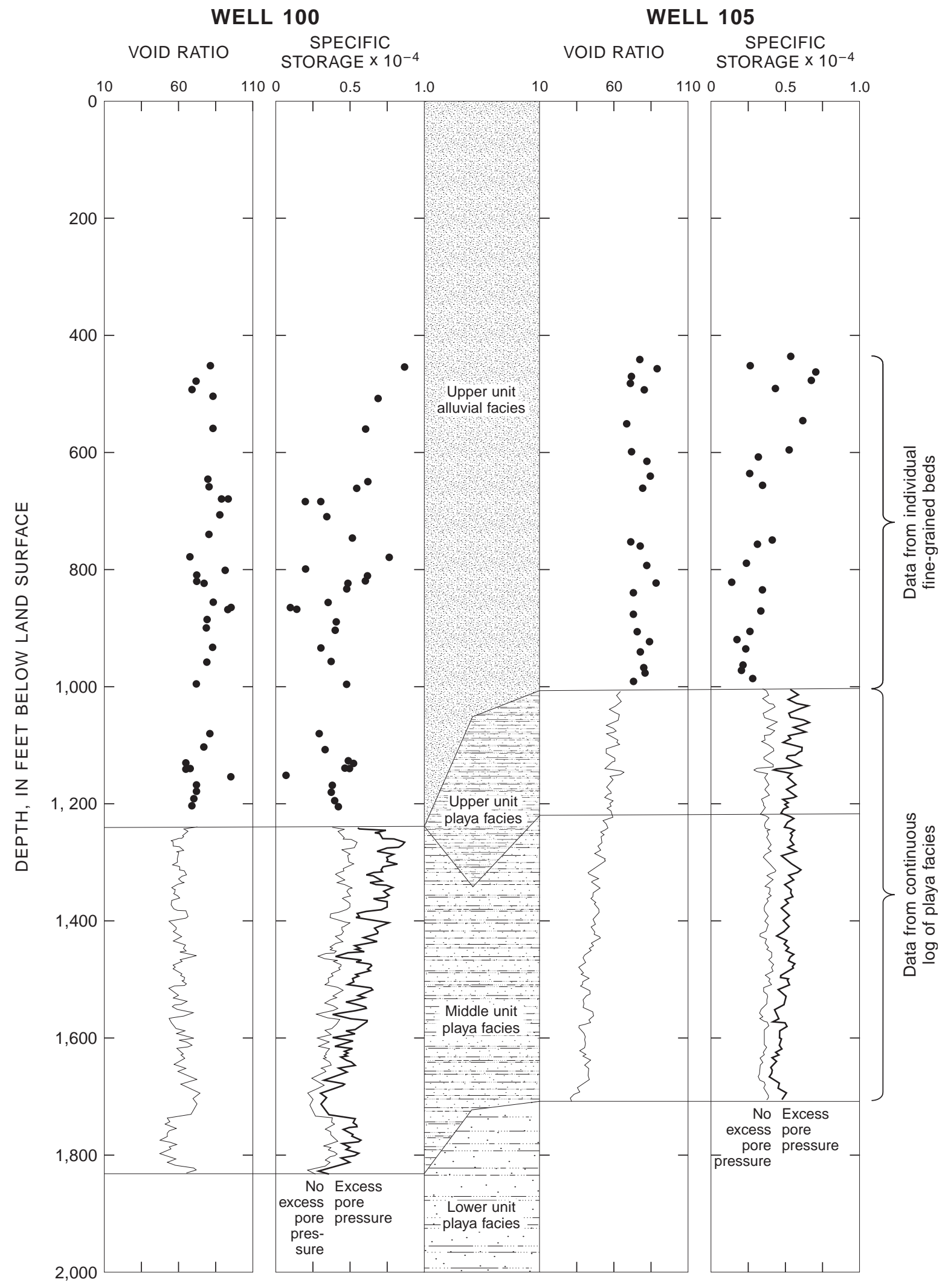

Figure 32. Calculated void ratio and specific storage at wells 100 and 105. 
These calculations indicate that excess pore pressures may have existed at depth within the playa facies at well 100. Excess pore pressures at well 105 are less likely than at well 100 because well 105 is in closer proximity to permeable alluvial deposits near the basin margin, and excess pressures could drain more rapidly.

The vertical trends in calculated void ratio and specific storage for fine-grained sediments probably indicate that specific-storage values are greatest within the high-porosity zones of the playa facies of the upper and middle units. Maximum specific-storage values of fine-grained interbeds within the upper unit probably are similar to those of the playa facies, but average values probably are much less throughout most interbeds. This conclusion is supported by the results of one-dimensional compaction modeling (Epstein, 1987), which required specific-storage values of the playa facies that are about twice as large as the values for fine-grained interbeds in the alluvial facies. Large specific-storage values within the playa facies of the middle unit probably are restricted to the thick lowdensity sediments that occur at depth in the eastern and southern parts of the basin (fig. 9, geologic sections). Large values in the western part of the basin probably occur only within the playa facies of the upper unit, which is thin and restricted in areal extent (fig. 9, geologic sections A, B, and C).

\section{Gravity and Land-Subsidence Measurements of Storage Change and Storage Properties.-Changes in} gravity from 1967 to 1989 were used to evaluate changes in ground-water storage along a part of the primary level line. Measurement of temporal gravity as a method for estimating changes in subsurface storage of water has been suggested and used by a few investigators. Zohdy and others (1974) discussed the technique as a method for estimating specific yield in water-table aquifers, and the technique was applied by Montgomery (1971). The method also has been applied to geothermal reservoirs and compressible aquifers to gain a better understanding of mass flux. Decreases in gravity caused by subsurface-mass loss have been measured at the Wairakei geothermal field in New Zealand (Allis and Hunt, 1986) and the Geysers geothermal area in California (Isherwood, 1981). Strange and Wessels (1985) produced relations between temporal gravity and subsidence in Picacho Basin and the Central Valley of California. Data from Picacho Basin were further analyzed in this study to estimate the quantities of water that have been derived from dewatering and compaction of the aquifer system and to estimate specific yield.

Estimates of quantities of water derived from compaction and dewatering of pore spaces can be determined with contemporaneous measurements of land subsidence and gravity. Subsidence is a measure of the quantity of water derived from compaction of pores because the volume of pore-space compaction occurs as subsidence of the land surface. Correction of gravity change at bench marks for altitude change caused by subsidence yields a residual-gravity change that is a measure of the quantity of the water that has drained or filled pore spaces. Residual-gravity change can be used to estimate specific yield provided that information on water-table change is available.

Temporal gravity variations in areas of variable ground-water storage primarily result from two sourceschanges in subsurface-water mass and changes in landsurface altitude caused by compaction or expansion of the aquifer. The effect of water-mass change on gravity at the land surface depends on the spatial distribution of the mass change. The interval of mass change can be approximated as an infinite slab, provided that the lateral extent of the mass change is much greater than the depth to the interval. The gravitational effect of an infinite slab of water that is $1 \mathrm{ft}$ thick is $12.78 \mu \mathrm{gals}$ (Telford and others, 1976). A gal is the basic unit of gravitational acceleration and is equivalent to $1 \mathrm{~cm} / \mathrm{sec}^{2}$. The effect of altitude on gravity is equivalent to the local vertical gradient of gravity, which varies within a few percent of $-94 \mu \mathrm{gal} / \mathrm{ft}$ (Telford and others, 1976). Changes in water mass and land-surface altitude are associated with removal of water from compressible aquifers such as occur in Picacho Basin. Small changes in altitude are associated with water-table and incompressible aquifers; in these cases, changes in water mass are the primary cause of temporal-gravity variations.

Data on subsidence and changes in gravity are available for part of the primary level line in Picacho Basin for 1967-84 (fig. 33). These data have been analyzed to produce estimates of changes in the volume of saturated pores and amounts of storage change caused by compaction and dewatering of pores. Accurate specific-yield values cannot be determined because water levels were not measured coincident with the gravity and subsidence surveys; however, the general trend of specific yield can be determined qualitatively. 


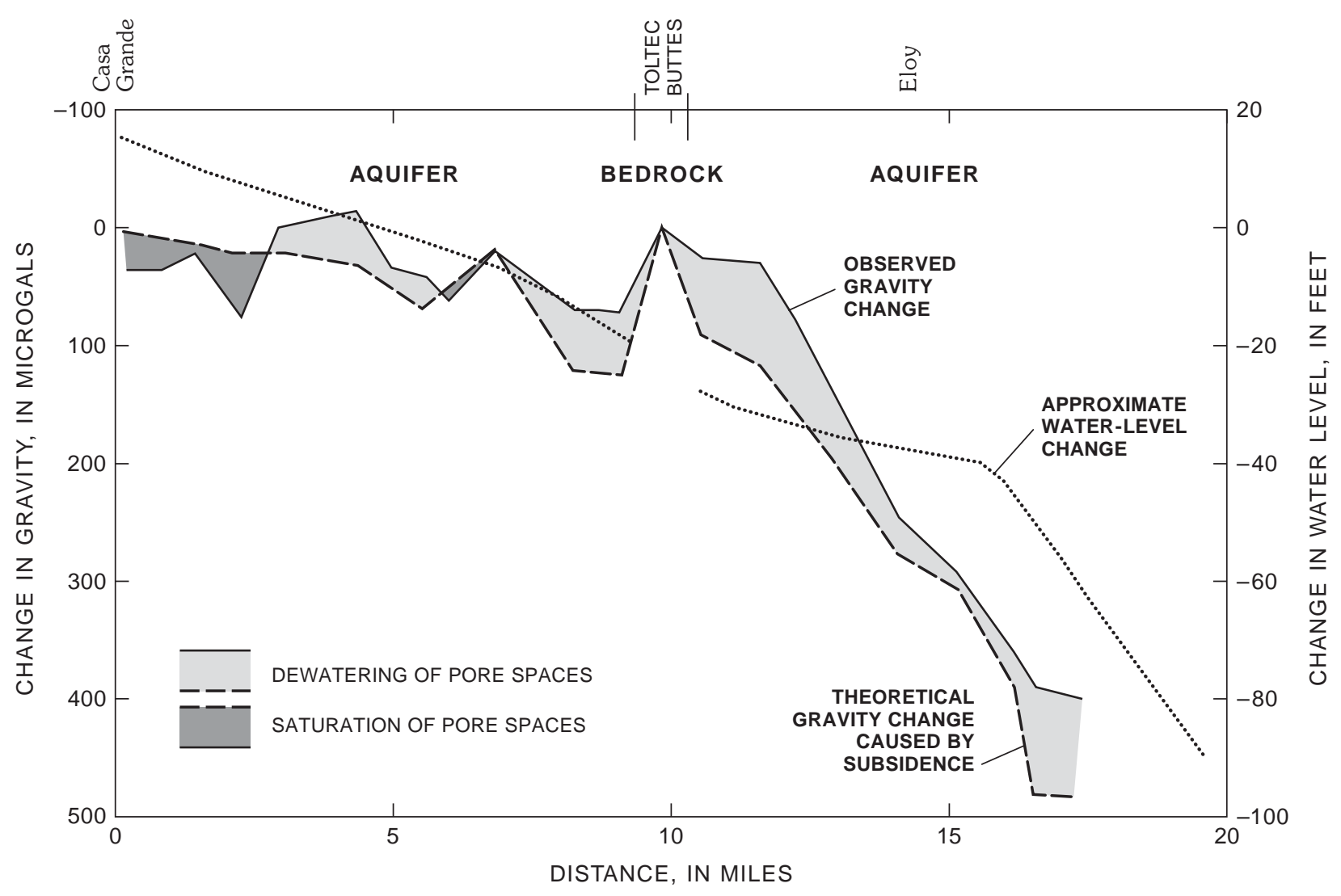

Figure 33. Gravity, water level, and ground-water storage changes along a portion of the primary level line, 1967-84.

Observed change in gravity, theoretical gravity change caused by subsidence, change in storage caused by dewatering or filling of pore spaces, and approximate water-level change are shown in figure 33. All gravity changes are referenced to a bedrock bench mark at Toltec Buttes where no gravity change and no subsidence are assumed to occur. Increases in observed gravity of less than $100 \mu$ gal occurred west of Toltec Buttes and increases of as much as $400 \mu \mathrm{gal}$ occurred east of Toltec Buttes.

A measure of the quantity of water that has drained or filled pore spaces from 1967 to 1984 can be determined by subtracting the theoretical gravity change caused by subsidence from the observed gravity change. Theoretical gravity change caused by subsidence is the sum of the effects of altitude change (-94 $\mu \mathrm{gal} / \mathrm{ft})$ and loss of water caused by compaction (12.78 $\mu \mathrm{gal} / \mathrm{ft})$ or about $-81 \mu \mathrm{gal} / \mathrm{ft}$ of subsidence. Theoretical gravity changes caused by subsidence along the primary level line (fig. 33) include increases of as much as $100 \mu \mathrm{gal}$ west of Toltec Buttes and nearly
$500 \mu$ gal east of Toltec Buttes. Drainage of pore spaces is indicated where the observed gravity change is less than the theoretical change caused by subsidence. Filling of pore spaces is indicated where the observed gravity change is greater than the theoretical change. Increased ground-water storage caused by filling of pore spaces occurred near Casa Grande and is equivalent to less than $50 \mu \mathrm{gals}$ or $4 \mathrm{ft}$ of water. Losses in ground-water storage caused by dewatering of pore spaces occurred throughout much of the rest of the primary level line and ranges from a few to $80 \mu \mathrm{gals}$, or about $6 \mathrm{ft}$ of water.

Water-level change for 1967-84 was approximated from water-level measurements in a few irrigation wells near the primary level line. The water-level change is assumed to be representative of water-table changes. The trend of water-table change along the level line is similar to the trend of change in saturated pore spaces. Water levels rose by about $15 \mathrm{ft}$ near Casa Grande and declined elsewhere including 40 to $60 \mathrm{ft}$ of decline near Eloy. Specific-yield values can be 
calculated at each bench mark if water levels are measured coincidently with gravity and subsidence. Water-level change was extrapolated from only a few nearby wells; therefore, water-level and specific-yield values near bench marks can be only generalized. Specific-yield values are less than 0.05 at Eloy, about 0.10 and 0.15 east and west of Eloy, respectively, and 0.15 to 0.25 near Casa Grande. These values are consistent with the general lithologies that occur near water-level altitudes along the level line. Water-level altitudes occur within fine-grained playa deposits at Eloy and coarse-grained alluvial deposits east of Eloy, near Toltec Buttes, and near Casa Grande.

Total change in aquifer-system storage at any location is the sum of storage change caused by compaction and draining or filling of pore spaces. The ratio of water withdrawn from aquifer-system compaction to total losses in aquifer-system storage along the primary level line for 1967-84 is shown in figure 34 . About 15 to 30 percent of the storage loss between Casa Grande and Eloy was derived from porespace compaction. More than half the storage loss near Eloy—about 50 to 80 percent—was derived from compaction of pores. These data indicate that the amounts of aquifer-system storage losses through compaction and dewatering of pore spaces generally correspond with lithology. Storage loss in regions of the aquifer system that are dominated by fine-grained sediments and confined conditions, such as the central area of the basin, primarily occurs through pore-space compaction. Storage loss on the basin margins, where the aquifer-system is dominated by coarse-grained sediments and water-table conditions, primarily occurs through drainage of pore spaces.

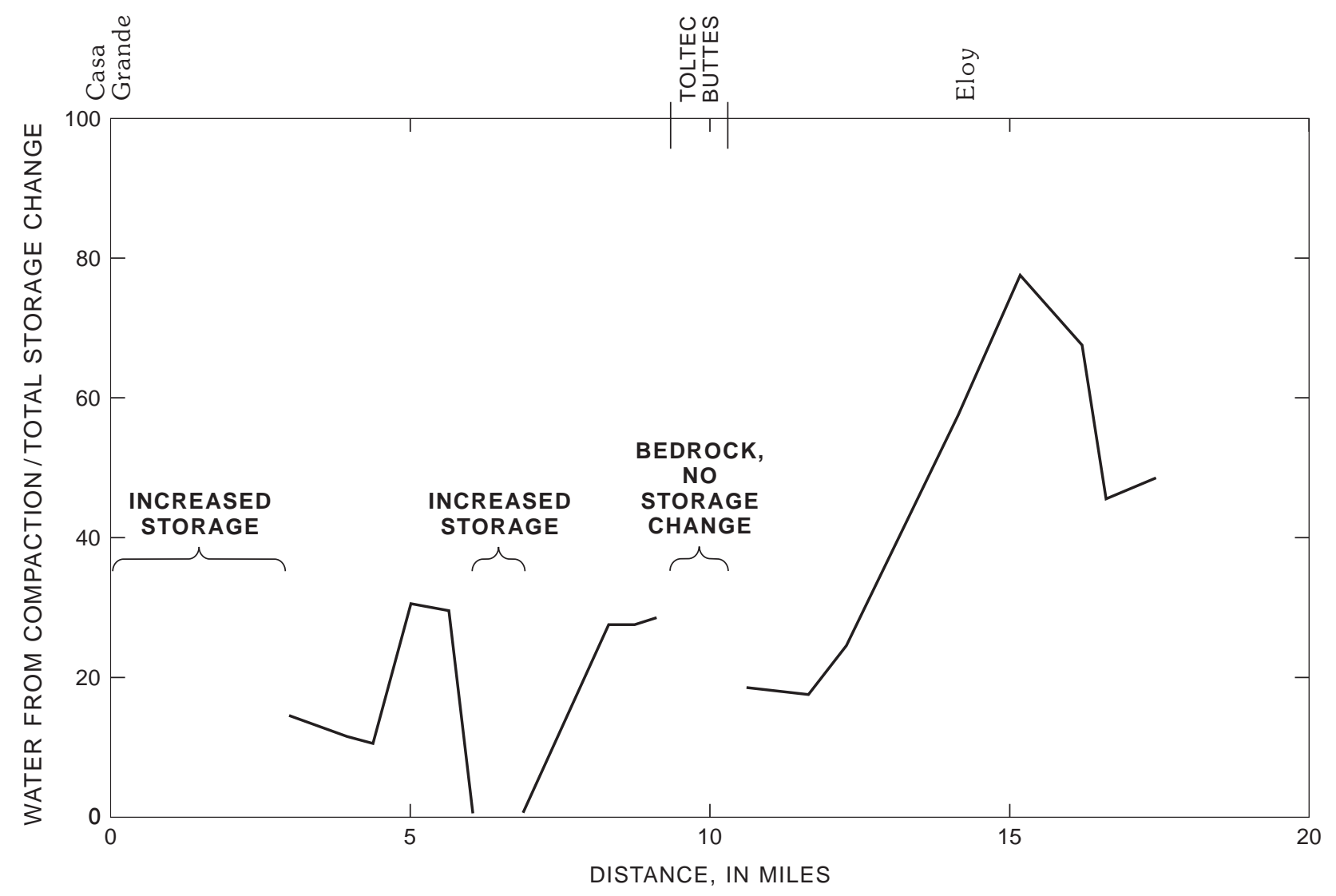

Figure 34. Ratio of ground water withdrawn from aquifer-system compaction to total ground water withdrawn from aquifersystem storage along a portion of the primary level line, 1967-84. 


\section{SUMMARY}

The hydrogeology of Picacho Basin was investigated before the development of a model for simulation of ground-water flow and land subsidence. The study required definition of the stratigraphy, physical properties, and hydraulic properties of the basin sediments; basin structure; and ground-water flow under predevelopment and postdevelopment conditions. The study relied on available data and existing reports; no additional data were collected. Several types of lithologic and geophysical information were used in describing the basin sediments and structure. This information includes lithologic logs, geophysical logs, particle-size analyses of drill cuttings, drillers' logs, seismic data, and gravity data.

The ground- water flow system and changes that have occurred since initial development were described through the use of previous investigations and available water-level and well-construction information.

The primary structure of Picacho Basin is an asymmetric graben, or rotated fault block, and the greatest structural relief and greatest thickness of basin sediments are on the east margin of the graben. The eastward-tilted structure is consistent with the pervasive listric normal faulting within the regional bedrock and oldest basin sediments. Most of the structural relief on the east margin of the basin probably was accommodated by high-angle normal faulting. Minor amounts of high-angle normal faulting may have occurred in other parts of the basin.

Basin sediments are separated into lower, middle, and upper hydrostratigraphic units, each of which contains alluvial and playa facies. The alluvial facies is composed of coarse-grained sediments that occur mainly on the basin margins. The playa facies is composed of fine-grained sediments that occur mainly in the basin center. The lower unit is as much as several thousand feet thick and contains a playa facies that includes a thick evaporite sequence of anhydrite and halite and an alluvial facies that is primarily conglomerate. The middle unit is as much as $1,500 \mathrm{ft}$ thick and contains an extensive playa facies that includes several hundred feet of gypsum in the northwestern part of the basin. The upper unit is as much as $1,500 \mathrm{ft}$ thick and consists primarily of alluvial deposits with local playa facies.

The physical properties and structural deformation of the middle and upper units differ significantly from those of the lower unit. The lower unit is deformed extensively by normal and listric normal faults at depth. Thicknesses of the middle and upper units increase across structures that bound the graben, and the units probably are displaced by high-angle normal faults along the east margin of the basin. Seismic-refraction surveys and logs of density, porosity, and sonic velocity indicate that the lower unit is more consolidated than the middle and upper units and that the contact between the lower and middle units is a significant change in physical properties. The contact between the middle and upper units is gradational, and physical properties of the units are similar.

The basin sediments contain the main waterbearing units. Ground-water flow occurs in lower and upper aquifer systems that are separated in the basin center by a middle confining unit. The lower aquifer system comprises conglomerate of the lower hydrostratigraphic unit and alluvial facies of the middle hydrostratigraphic unit that underlie the middle confining unit. The upper aquifer system comprises local aquifers and confining beds within the alluvial facies of the middle and upper hydrostratigraphic units. The middle confining unit comprises the playa facies of the lower, middle, and upper hydrostratigraphic units and restricts flow between aquifer systems. Ground water occurs under confined conditions in the lower aquifer system. Ground water in the upper aquifer system occurs under confined and water-table conditions. The hydraulic properties and compressibility of the middle and upper units are much greater than those of the lower unit. Most ground-water flow is horizontal; however, vertical-head gradients exist, and vertical flow occurs within the upper aquifer system and between the lower and upper aquifer systems.

The predevelopment ground-water flow system was dominated by underflow into and out of the basin, recharge through streamflow infiltration along the Gila River, and evapotranspiration. Development of the ground-water and surface-water supplies resulted in significant changes in the distribution of recharge and discharge. Early development of surface-water supplies of the Gila River began in the late 1800's and resulted in increased recharge through infiltration along the irrigation-distribution system in the northern part of the basin. Extensive development of the ground-water supplies began in the 1930's, and much of the basin was irrigated by the early 1950's. Ground-water withdrawals that exceeded recharge resulted in extensive water-level declines, changes in direction of ground-water flow, removal of water from aquifer-system storage, aquifer-system compaction, land subsidence, and development of earth fissures. Before 1950, most ground water was withdrawn from 
the upper aquifer system; these withdrawals resulted in less than $100 \mathrm{ft}$ of water-level decline, elastic compaction of the aquifer system, and about $0.5 \mathrm{ft}$ of subsidence. Development after 1950 included withdrawals from the lower aquifer system. These additional withdrawals resulted in water-level declines of as much as $350 \mathrm{ft}$, inelastic compaction of the aquifer system, and the development of vertical hydraulic-head gradients within the upper aquifer system and between the upper and lower aquifer systems. Land subsidence had occurred throughout much of the basin by 1984, and as much as $15 \mathrm{ft}$ of subsidence occurred south of Eloy. Most aquifersystem compaction has occurred in the middle confining unit and fine-grained interbeds of the upper aquifer system.

Ground-water withdrawals in excess of recharge have resulted in losses in aquifer-system storage through drainage of pore spaces in water-table aquifers and reduction in pore volume within confining units. Most storage loss has occurred through dewatering of pores in the upper aquifer system; however, significant storage losses occurred through the loss of pore volume in the middle confining unit and fine-grained interbeds of the upper aquifer system. The mechanism of groundwater storage change is dependent on the dominant lithology of the aquifer system, which varies across the basin. Storage changes since 1967 have occurred primarily through dewatering or saturation of pores in the Casa Grande area and loss of pore volume in the Eloy area. As much as 80 percent of the water withdrawn from storage in the Eloy area since 1967 has been derived from compaction of confining units.

\section{SELECTED REFERENCES}

Aiken, C.L.V., Lysonski, J.C., Sumner, J.S., Hahman, W.R., Sr., 1981, A series of 1:250,000 complete residual bouguer gravity anomaly maps of Arizona, in Stone, Claudia, and Jenney, J.P., eds.: Arizona Geological Society Digest, v. 13, p. 31-38.

Allen, Alice, 1984, Types of land subsidence, in Poland, J.F., ed., Guidebook to Studies of Land Subsidence due to Ground-Water Withdrawal: Chelsea, Michigan, Book Crafters, p. 133-142.

Allis, R.G., and Hunt, T.M., 1986, Analysis of exploitation induced gravity changes at Wairakei geothermal field: Geophysics, v. 51, no. 8, p. 1647-1660.
Anderson, S.R., 1988, Potential for aquifer compaction, land subsidence, and earth fissures in the Tucson Basin, Pima County, Arizona: U.S. Geological Survey Hydrologic Investigations Atlas HA-713, 3 sheets. 1989, Potential for aquifer compaction, land subsidence, and earth fissures in Avra Valley, Pima and Pinal Counties, Arizona: U.S. Geological Survey Hydrologic Investigations Atlas HA-718, 3 sheets.

Anderson, T.W., 1968, Electric-analog analysis of groundwater depletion in central Arizona: U.S. Geological Survey Water-Supply Paper 1860, 21 p. 1980, Study plan for the regional aquifer-system analysis of alluvial basins in south-central Arizona and adjacent States: U.S. Geological Survey Open-File Report 80-1197, 22 p. 1986, Geohydrology of the southwest alluvial basins, Arizona, in Anderson, T.W., and Johnson, A.I., eds., Regional Aquifer Systems of the United States, Southwest Alluvial Basins of Arizona: American Water Resources Association Monograph Series 7, p. 99-111.

Babcock, H.M., 1970, Ground-water conditions in the Gila River Indian Reservation, Pinal and Maricopa Counties, Arizona: U.S. Geological Survey open-file report, 41 p.

Brooks, W.E., 1986, Distributions of anomalously high $\mathrm{K}_{2} \mathrm{O}$ volcanic rocks in Arizona-Metasomatism at the Picacho Peak detachment fault: Geology, v. 14, no. 4, p. 339-342.

Brown, J.G., and Pool, D.R., 1989, Hydrogeology of the western part of the Salt River Valley area, Maricopa County, Arizona: U.S. Geological Survey WaterResources Investigations Report 88-4202, 5 sheets.

Bureau of Reclamation, 1977, Central Arizona ProjectGeology and groundwater resources report-Maricopa and Pinal Counties, Arizona: Bureau of Reclamation report, 2 volumes.

Byars, D.D., 1975, The Casa Grande photogrammetric test range: American Society of Photogrammetry, 1975 Fall Convention Proceedings, Phoenix, Arizona, p. 162-176.

Christie, F.J., 1978, Analysis of gravity data from the Picacho Basin, Pinal County, Arizona: Tucson, University of Arizona, unpublished master's thesis, $105 \mathrm{p}$.

Cummings, R.B., 1982, Geology of the Sacaton porphyry copper deposit, Pinal County, Arizona, in Titley, S.R., ed., Advances in Geology of the Porphyry Copper Deposits, Southwestern North America: Tucson, Arizona, University of Arizona Press, p. 507-521.

Damon, P.E., Lynch, D.J., and Shafiqullah, Mohammed, 1984, Cenozoic landscape development in the Basin and Range Province of Arizona, in Smiley, T.L., Nations, J.D., Pèwè, T.L., and Schafer, J.P., eds., Landscapes of Arizona-The Geological Story: Tucson, University of Arizona Press, p. 175-206. 
Dana, E.S., 1965, Dana's manual of mineralogy, 17th edition, Hurlbut, C.S., Jr., ed.: New York, John Wiley and Sons, $609 \mathrm{p}$.

Davis, A.P., 1897a, Irrigation near Phoenix, Arizona: U.S. Geological Survey Water-Supply and Irrigation Paper 2, $98 \mathrm{p}$.

$1897 \mathrm{~b}$, Report on the irrigation investigation for the benefit of the Pima and other Indians on the Gila River Indian Reservation, Arizona: Washington, D.C., 54th Congress, 2d session, Senate Document 27, 56 p.

Davidson, E.S., 1973, Geohydrology and water resources of the Tucson Basin, Arizona: U.S. Geological Survey Water-Supply Paper 1939-E, 81 p.

Eberley, L.D., and Stanley, T.B., 1978, Cenozoic stratigraphy and geologic history of southwestern Arizona: Geological Society of America Bulletin, v. 89, no. 6, p. 921-940.

Epstein, V.J., 1987, Hydrologic and geologic factors affecting land subsidence near Eloy, Arizona: U.S. Geological Survey Water-Resources Investigations Report 87-4143, 28 p.

Feth, J.H., 1951, Structural reconnaissance of the Red Rock quadrangle, Arizona: U.S. Geological Survey open-file report, $32 \mathrm{p}$.

Freethey, G.W., and Anderson, T.W., 1986, Predevelopment hydrologic conditions in the alluvial basins of Arizona and adjacent parts of California and New Mexico: U.S. Geological Survey Hydrologic Investigations Atlas HA-664, 3 sheets.

Freethey, G.W., Pool, D.R., Anderson, T.W., and Tucci, Patrick, 1986, Description and generalized distribution of aquifer materials in the alluvial basins of Arizona and adjacent parts of California and New Mexico: U.S. Geological Survey Hydrologic Investigations Atlas HA-663, 4 sheets.

Freeze, R.A., and Cherry, J.A., 1979, Groundwater: Englewood Cliffs, New Jersey, Prentice-Hall, Inc., $604 \mathrm{p}$.

Gatewood, J.S., Robinson, T.W., Colby, B.R., Hem, J.D., and Halpenny, L.C., 1950, Use of water by bottom-land vegetation in Lower Safford Valley, Arizona: U.S. Geological Survey Water-Supply Paper 1103, 210 p.

Halpenny, L.C., and others, 1952, Ground water in the Gila River Basin and adjacent areas, Arizona-A summary: U.S. Geological Survey open-file report, 224 p.

Hardt, W.F., and Cattany, R.E., 1965, Description and analysis of the geohydrologic system in western Pinal County, Arizona: U.S. Geological Survey open-file report, $92 \mathrm{p}$.

Helm, D.C., 1975, One-dimensional simulation of aquifersystem compaction near Pixley, California-1, Constant parameters: American Geophysical Union, Water Resources Research, v. 11, no. 3, p. 465-478.
Holzer, T.L., 1978, Results and interpretation of exploratory drilling near the Picacho Fault, south-central Arizona: U.S. Geological Survey Open-File Report 78-1016, $38 \mathrm{p}$. 1981, Preconsolidation stress of aquifer systems in areas of induced land subsidence: American Geophysical Union, Water Resources Research, v. 17, no. 3, p. 693-704.

Holzer, T.L., Davis, S.N., and Lofgren, B.E., 1979, Faulting caused by ground-water extraction in south-central Arizona: American Geophysical Union, Journal of Geophysical Research, v. 84, no. B2, p. 603-612.

Isherwood, W.F., 1981, Geophysical overview of The Geysers, in McLaughlin, R.J., and Donnelly-Nolan, J.M., eds., Research in the Geysers-Clear Lake Geothermal area, Northern California: U.S. Geological Survey Professional Paper 1141, p. 83-96.

Jachens, R.C., and Holzer, T.L., 1979, Geophysical investigations of ground failure related to ground-water withdrawal, the Picacho Basin, Arizona: Ground Water, v. 17 , no. 6, p. 574-585.

Jorgensen, D.G., 1980, Relationships between basic soilsengineering equations and basic ground-water flow equations: U.S. Geological Survey Water-Supply Paper 2064, 40 p.

Konieczki, A.D., and English, C.S., 1979, Map showing ground-water conditions in the lower Santa Cruz area, Pinal, Pima, and Maricopa Counties, Arizona-1977: U.S. Geological Survey Water-Resources Investigations Report 79-56, 4 sheets.

Konieczki, A.D., and Anderson, S.R., 1990, Evaluation of ground-water recharge along the Gila River as a result of the flood of October 1983, in and near the Gila River Indian Reservation, Maricopa and Pinal Counties, Arizona: U.S. Geological Survey Water-Resources Investigations Report 89-4148, 30 p.

Laney, R.L., and Hahn, M.E., 1986, Hydrogeology of the eastern part of the Salt River Valley area, Maricopa and Pinal Counties, Arizona: U.S. Geological Survey Water-Resources Investigations Report 86-4147, 4 sheets.

Laney, R.L., and Pankratz, L.W., 1987, Investigations of land subsidence and earth fissures near the Salt-Gila aqueduct, Maricopa and Pinal Counties, Arizona: U.S. Geological Survey Miscellaneous Investigations Series Map I-1892-A, 1 sheet.

Laney, R.L., Raymond, R.H., and Winikka, C.C., 1978, Maps showing water-level declines, land subsidence, and earth fissures in south-central Arizona: U.S. Geological Survey Water-Resources Investigations Report 78-83, 2 sheets.

Lee, W.T., 1904, The underground waters of Gila Valley, Arizona: U.S. Geological Survey Water-Supply and Irrigation Paper 104, 71 p. 
Leonard, R.J., 1929, An earth fissure in southern Arizona: Journal of Geology, v. 37, no. 8, p. 765-774.

Lippincott, J.B., 1900, Storage of water on Gila River, Arizona: U.S. Geological Survey Water-Supply and Irrigation Paper 33, 98 p.

Lohman, S.W., 1979, Ground-water hydraulics: U.S. Geological Survey Professional Paper 708, 70 p.

Lohman, S.W., and others, 1972, Definitions of selected ground-water terms-Revisions and conceptual refinements: U.S. Geological Survey Water-Supply Paper 1988, $21 \mathrm{p}$.

Montgomery, E.L., 1971, Estimation of coefficient of storage by use of gravity techniques: Tucson, Arizona, University of Arizona, unpublished doctoral dissertation, $144 \mathrm{p}$.

McDonald, M.G., and Harbaugh, A.W., 1988, A modular three-dimensional finite-difference ground-water flow model: U.S. Geological Survey Techniques of WaterResources Investigations, book 6, chap. A1, 576 p.

Nason, P.W., Shaw, A.V., and Aveson, K.D., 1982, Geology of the Poston Butte Porphyry Copper Deposit, Pinal County, Arizona, in Titley, S.R., ed., Advances in Geology of the Porphyry Copper Deposits, Southwestern North America: Tucson, Arizona, University of Arizona Press, p. 507-521.

Niccoli, M.A., and Long, M.R., 1981, Determination of transmissivity values in the Salt River Valley using recovery tests, specific capacity data, and DWR driller log program, in Harwood, Gerald, ed., Hydrology and Water Resources of the Southwest: American Water Resources Association, Arizona Section, and Arizona Academy of Science, Hydrology Section, Proceedings of the 1981 Meeting, Tucson, Arizona, May 1-2, 1981, v. 11, p. 117-124.

Olberg, C.R., 1915, Unpublished report on the water supply and the estimated cost of the proposed San Carlos Irrigation Project on the Gila River, Arizona: Los Angeles, California, U.S. Department of Interior, U.S. Indian Service, 224 p. with appendices and maps. 1919, Report on the San Carlos Irrigation Project: Washington, D.C., 66th Congress, Indians of the U.S., Hearing before the Committee on Indian Affairs, House of Representatives, 1st session, v. 2, Appendix A, p. 1-102.

Oppenheimer, J.M., 1980, Gravity modeling of the alluvial basins, southern Arizona: Tucson, Arizona, University of Arizona, unpublished master's thesis, $81 \mathrm{p}$.

Oppenheimer, J.M., and Sumner, J.S., 1981, Gravity modeling of the basins in the Basin and Range Province, Arizona: Arizona Geological Society Digest, v. 13, p. 111-115.
Pankratz, L.W., Ackermann, H.D., and Jachens, R.C., 1978, Results and interpretation of geophysical studies near the Picacho Fault, south-central Arizona: U.S. Geological Survey Open-File Report 78-1106, 17 p.

Parker, T.J., and McDowell, A.N., 1955, Model studies of salt dome tectonics: American Association of Petroleum Geologists Bulletin, v. 39, no. 12, p. 2384-2470.

Peirce, H.W., 1974, Thick evaporites in the Basin and Range province-Arizona, in Fourth Symposium on Salt: Cleveland, Northern Ohio Geological Society, p. 47-55.

Poland, J.F., Lofgren, B.E., and Riley, F.S., 1972, Glossary of selected terms useful in studies of the mechanics of aquifer systems and land subsidence due to fluid withdrawal: U.S. Geological Survey Water-Supply Paper 2025, 9 p.

Pool, D.R., 1986, Aquifer geology of alluvial basins of Arizona, in Anderson, T.W. and Johnson, A.I., eds., Regional Aquifer Systems of the United States, Southwest Alluvial Basins of Arizona: American Water Resources Association Monograph Series 7, p. 25-36.

Riley, F.S., 1969, Analysis of borehole extensometer data from central California, in Tison, L.J., ed., Land Subsidence: Tokyo, International Association of Scientific Hydrology Publication 89, v. 2, p. 423-431.

Reynolds, S.J., 1988, Geologic map of Arizona: Tucson, Arizona, Arizona Geological Survey Map 26, scale 1:1,000,000, 1 sheet.

Robinson, G.M., and Peterson, D.E., 1962, Notes on earth fissures in southern Arizona: U.S. Geological Survey Circular 466, 7 p.

Robinson, T.W., 1965, Introduction, spread, and areal extent of saltcedar (Tamarix) in the western States: U.S. Geological Survey Professional Paper 491-A, 11 p.

Rott, E.H., Jr., 1936, Report on the geology and water resources of the Gila River Indian Reservation: U.S. Department of Agriculture, Soil Conservation Service unpublished report, $91 \mathrm{p}$.

Scarborough, R.B., and Peirce, H.W., 1978, Late Cenozoic basins of Arizona, in Callender, J.F., Wilt, J.C., and Clemmons, R.E., eds., Land of Cochise: New Mexico Geological Society Guidebook, 29th Field Conference, p. 253-259.

Scarborough, R.B., Menges, C.M., and Pearthree, P.A., 1983, Map of Basin and Range (Post-15 m.y.a.) exposed faults, grabens, and basalt-dominated volcanism in Arizona: Tucson, Arizona Geological Survey Open-File Report 83-21, 25 p. 1986, Map of Late Pliocene-Quaternary (Post-4 m.y.) faults, folds, and volcanic outcrops in Arizona: Tucson, Arizona Geological Survey Map 22, scale 1:1,000,000, 1 sheet. 
Schumann, H.H., 1986, Ground-water depletion and land subsidence in western Pinal County, Arizona, in Proceedings of the FOCUS Conference on Southwestern Ground Water Issues: Dublin, Ohio, National Water Well Association, October 20-22, 1986, Tempe, Arizona p. 533-552.

Schumann, H.H., and Poland, J.F., 1970, Land subsidence, earth fissures, and ground-water withdrawal in south-central Arizona, U.S.A., in Land subsidence: Tokyo International Association of Scientific Hydrology Publication 88, v. 1, p. 295-302.

Sellers, W.D., Hill, R.H., and Sanderson-Rae, M., 1985, Arizona climate-The first hundred years: Tucson, Arizona, University of Arizona Press, 143 p.

Shafiqullah, M., Damon, P.E., Lynch, D.J., Reynolds, S.J., Rehrig, W.A., and Raymond, R.H., 1980, K-Ar geochronology and geologic history of southwestern Arizona and adjacent areas, in Jenney, J.P. and Stone, Claudia, eds., Studies in Western Arizona: Tucson, Arizona Geological Society Digest 12, p. 201-260.

Smith, G.E.P., 1940, The groundwater supply of the Eloy District in Pinal County, Arizona: University of Arizona, College of Agriculture, Agricultural Experiment Station Technical Bulletin 87, 41 p.

Smith, L.P., 1981, Long-term streamflow histories of the Salt and Verde Rivers, Arizona, as reconstructed from tree-rings: U.S. Army Corps of Engineers contract report DACW-09-80-C-0071, 129 p.

Smith, L.P., and Stockton, C.W., 1981, Reconstructed stream flow for the Salt and Verde Rivers from tree-ring data: Middleburg, Virginia, American Water Resources Association, Water Resources Bulletin, v. 17, no. 6, p. 939-947.

Southworth, C.L., 1919, The history of irrigation along the Gila River: Washington, D.C., 66th Congress, Indians of the U.S., Hearings before the Committee on Indian Affairs, House of Representatives, 1st session, v. 2, Appendix A, p. 103-291.

Strange, W.E., 1983, Subsidence monitoring for the State of Arizona: Washington, D.C., U.S. Department of Commerce, National Oceanic and Atmospheric Administration report, $74 \mathrm{p}$.

Strange, W.E., and Wessels, C.W., 1985, Analysis of repeat gravity measurements in areas of ground-water withdrawal due to subsidence [abs.]: American Geophysical Union, 1985 Spring Meeting, EOS Transactions, v. 66, no. 18, p. 364.

Telford, W.M., Geldart, L.P., Sheriff, R.E., and Keys, D.A., 1976, Applied geophysics: New York, Cambridge University Press, 860 p.
Thomsen, B.W., and Baldys, Stanley, III, 1985, Groundwater conditions in and near the Gila River Indian Reservation, south-central Arizona: U.S. Geological Survey Water-Resources Investigations Report 854073, 2 sheets.

Tucci, Patrick, Schmoker, J.W., and Robbins, S.L., 1982, Borehole-gravity surveys in basin-fill deposits in central and southern Arizona: U.S. Geological Survey Open-File Report 82-473, 23 p.

Tucci, Patrick, and Pool, D.R., 1986, Use of geophysics for geohydrologic studies in the alluvial basins of Arizona, in Anderson, T.W., and Johnson, A.I., eds., Regional aquifer systems of the United States, Southwest Alluvial Basins of Arizona: American Water Resources Association Monograph Series 7, p. 37-56.

Turner, R.M., 1974, Quantitative and historical evidence of vegetation changes along the upper Gila River, Arizona: U.S. Geological Survey Professional Paper 655-H, $20 \mathrm{p}$.

Turner, S.F., and others, 1943, Ground-water resources of the Santa Cruz Basin, Arizona: U.S. Geological Survey open-file report, $84 \mathrm{p}$.

U.S. Geological Survey, 1954, Compilation of records of surface waters of the United States through September 1950, Part 9, Colorado River Basin: U.S. Geological Survey Water-Supply Paper 1313, 749 p.

1986, Annual summary of ground-water conditions in Arizona, Spring 1984 to Spring 1985: U.S. Geological Survey Open-File Report 86-422W, 1 sheet.

U.S. Soil and Conservation Service, 1936, Woodland type map, Gila River Indian Reservation, Arizona: U.S. Department of Agriculture, Soil Conservation Service map, scale 1:62,500.

Wallace, B.L, Wrege, B.M., and Schumann, H.H., 1986, Geohydrologic data along the Salt-Gila aqueduct of the Central Arizona Project in Maricopa and Pinal Counties, Arizona: U.S. Geological Survey Open-File Report 86-236, 49 p.

Wickham, M.P., and Corkhill, E.F., 1989, Pinal AMA regional groundwater flow model, Phase 1, Hydrogeologic framework, water budget and Phase 1 recommendations: Phoenix, Arizona, Arizona Department of Water Resources, 63 p.

Winikka, C.C., 1964, Subsidence in the Eloy-Picacho area, in Proceedings of the Tenth and Eleventh Arizona Land Surveyors' Conference: Tucson, University of Arizona, Engineering Experiment Station Publication 121, p. 39-43.

Zohdy, A.A.R., Eaton, G.P., Mabey, D.R., 1974, Application of surface geophysics to ground-water investigations: U.S. Geological Survey Techniques of Water-Resources Investigations, book 2, chap. D1, $116 \mathrm{p}$. 
Selected References 65 